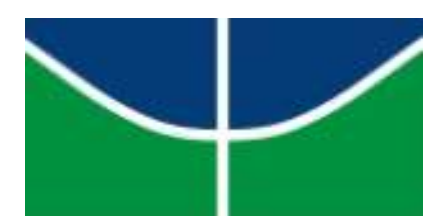

UNIVERSIDADE DE BRASÍLIA

FACULDADE DE EDUCAÇÃO

PROGRAMA DE PÓS-GRADUAÇÃO

O INFANTIL NA CONSTITUIÇÃO DA SUBJETIVIDADE: O

MEMORIAL EDUCATIVO DE PROFESSORES EM ESCRITA E AÇÃO

KATILEN MACHADO VICENTE SQUARISI

BRASÍLIA, 2016 
Ficha catalográfica elaborada automaticamente, com os dados fornecidos pela autora

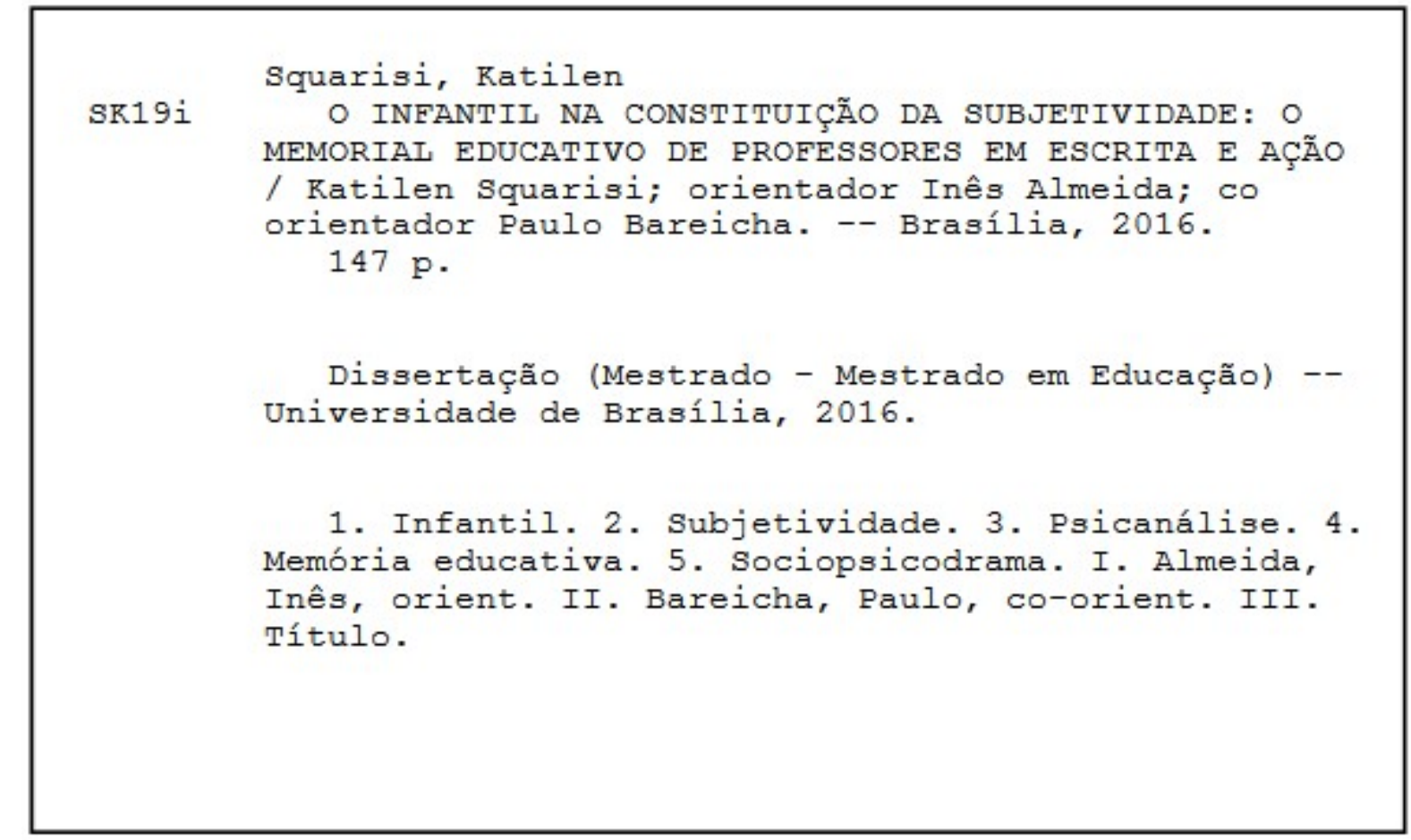




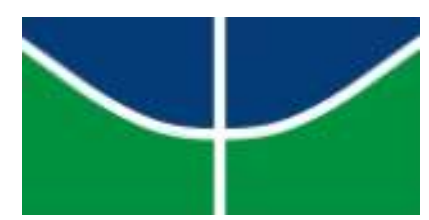

UNIVERSIDADE DE BRASÍLIA

FACULDADE DE EDUCAÇÃO

PROGRAMA DE PÓS-GRADUAÇÃO

\title{
O INFANTIL NA CONSTITUIÇÃO DA SUBJETIVIDADE: O MEMORIAL EDUCATIVO DE PROFESSORES EM ESCRITA E AÇÃO
}

\author{
KATILEN MACHADO VICENTE SQUARISI
}

Dissertação apresentada ao Programa de Pós-graduação em Educação da Faculdade de Educação, Universidade de Brasília. Linha de pesquisa: escola, aprendizagem, ação pedagógica e subjetividade na educação, como requisito final à obtenção do título de Mestre em Educação, sob a orientação da Prof ${ }^{a}$. Dra . Inês Maria Marques Zanforlin Pires de Almeida e coorientação do Prof. Dr. Paulo Sérgio de Andrade Bareicha.

Brasília-DF, 2016 
O infantil na constituição da subjetividade: o memorial educativo de professores em escrita e ação.

Katilen Machado Vicente Squarisi

Dissertação apresentada ao Programa de Pós-graduação em Educação da Faculdade de Educação, Universidade de Brasília. Linha de pesquisa: escola, aprendizagem, ação pedagógica e subjetividade na educação, como requisito final à obtenção do título de Mestre em Educação.

BANCA EXAMINADORA:

\section{Prof ${ }^{\mathrm{a}}$. Dr ${ }^{\mathrm{a}}$. Inês Maria Zanforlin Pires de Almeida \\ Universidade de Brasília - Orientadora}

Prof $^{\text {a }}$. Dr ${ }^{\text {a }}$. Cláudia Márcia Lyra Pato

Faculdade de Educação - Universidade de Brasília-UnB

Prof. Dr. Luiz Augusto Monnerat Celes

Instituto de Psicologia - Universidade de Brasília-UnB

\section{Prof $^{\mathrm{a}}$. Dr ${ }^{\mathrm{a}}$. Claudia Valéria de Assis Dansa \\ Universidade de Brasília - Suplente}

Brasília- DF 


\section{DEDICATÓRIA}

A Deus, razão do meu existir, e à minha família, pelo amor incondicional que nos une. 


\section{AGRADECIMENTOS}

A Deus por cuidar tanto de mim, por ser minha fortaleza em todos os momentos, minha constituição mais plena, que me motiva a ser uma pessoa melhor a cada dia. A Nossa Senhora das Graças, pela realização do mestrado, sonho idealizado em ti, minha mãe do céu.

Aos meus pais, Paulo e Vilma, meus irmãos Paulo Júnior e Érica, por me amarem sem medida e me conduzirem no caminho da fé, incentivando-me, sendo minha maior inspiração.

Aos meus filhos, João Marcelo e Rafael, presentes de Deus em minha vida e ao meu companheiro de tantos anos, Marcelo Abi, pela torcida, apoio, incentivo, ajuda incansável, paciência e por viverem essa realização comigo.

A minha afilhada Isabela e meus sobrinhos Paulo Neto e Marina, pela alegria irradiante e por fazerem minha vida mais feliz e divertida.

A minha sogra, Dad, e cunhada, Thaís, pelo carinho, incentivo e escuta acolhedora.

Aos meus afilhados amados que me fazem ir além, me ensinando a não desistir.

As minhas amigas do coração pela torcida, incentivo e apoio constantes.

A minha querida e amada orientadora, Prof ${ }^{\mathrm{a}}$. Dr ${ }^{\mathrm{a}}$. Inês Maria Zanforlin Pires de Almeida, minha gratidão por acreditar no meu sonho, pela oportunidade de tantos momentos preciosos e regados de amor. Pela amizade, constituída para além da vida acadêmica, "não por acaso nos encontramos", por tantas lições com leveza e seriedade no trabalho. Por tanta sabedoria. Minha admiração a quem tenho uma dívida simbólica impagável.

Ao meu coorientador, Prof. Dr. Paulo Sérgio de Andrade Bareicha, pelo privilégio e oportunidade de tantos conhecimentos, pelas contribuições significativas e relevantes que fizeram toda a diferença. Pelo exemplo de sabedoria e paciência.

A Prof a . Dr a . Cláudia Márcia Lyra Pato, pelo olhar atento, pelo cuidado e dedicação, pelas valiosas contribuições e conhecimento compartilhado. Que, com as aulas brilhantes, fez- 
me apaixonar pelo sujeito ecológico. Pelas sugestões ao projeto, na qualificação, e pela disponibilidade de participar da banca de defesa, oportunizando a realização desta conquista.

Aos membros da banca pelas trocas de conhecimentos e sugestões enriquecedoras. Em especial, ao Prof. Dr. Luiz Celes pelo privilégio de ter sido sua aluna, sendo inspiração em muitos momentos e do qual muito me honra tê-lo como membro da banca de defesa.

A Prof ${ }^{a}$. Dr ${ }^{a}$. Leny Mrech, que tive a alegria de conhecer, pelas trocas significativas e inspiradoras.

Ao corpo docente da Pós Graduação em Educação da Universidade de Brasília (UnB) em especial às Professoras Doutoras Teresa Cristina, Inês Maria, Cláudia Pato, Viviane Legnanni, Leila Chalub pelo profissionalismo e competência.

As minhas amigas e companheiras desta trajetória, em especial Jéssica Lago, Cláudia Aguiar e Eduardo, Elis Amaro, Cristiane Almeida, Mariana Behr, Aricélia Nascimento, Fernanda Távora, Thaiane Ferreira, Angélica Miotto, Bianca Salomão, Adriana Miranda, Luana Chaves e meu amigo Mauro Gleisson pelos laços que nos constituem e por tantos momentos regados de conhecimento e afeto.

Às amigas orientadoras educacionais da Secretaria de Educação pelos anos de convivência e trocas inspiradoras que admiro. Pela torcida amorosa.

Aos meus alunos da graduação, que me inspiram e incentivam a cada dia.

À Intersecção Psicanalítica do Brasil, pelas trocas, vivências, reflexões e estudos fortalecendo e enriquecendo meu trabalho. Em especial a Rosana Aguiar.

À Escola participante da pesquisa, a direção, coordenação, professoras e funcionários, pela acolhida, carinho, confiança e disponibilidade ao longo do processo.

À Escola de Aperfeiçoamento dos Profissionais de Educação - Eape, pela parceria e atenção constante, possibilitando a realização da pesquisa. 
Como psicanalista, estou destinado a me interessar mais pelos processos emocionais que pelos intelectuais, mais pela vida mental inconsciente que pela consciente. Minha emoção ao encontrar meu velho-mestre escola adverte-me de que antes de tudo, devo admitir uma coisa: é difícil dizer se o que exerceu mais influência sobre nós e teve importância maior foi nossa preocupação pelas ciências que nos eram ensinadas, ou pela personalidade de nossos mestres.

Sigmund Freud (1913) 


\section{RESUMO}

Este trabalho, inscreve-se a partir da indagação de como o professor compreende o significado da dimensão do infantil em sua constituição subjetiva e as possíveis repercussões no ofício docente à luz do aporte psicanalítico. Como objetivos específicos, destacam-se: reconhecer que a dimensão do infantil ocupa lugar de centralidade na constituição da subjetividade docente com repercussões no processo educativo em sala de aula; identificar possíveis implicações da atuação do professor das séries iniciais do ensino fundamental na constituição da subjetividade infantil; e a articulação da memória educativa e sociopsicodrama. A pesquisa foi realizada na abordagem metodológica qualitativa através do dispositivo da memória educativa, registros no diário de campo, entrevistas semiestruturadas e oficinas com utilização do sociopsicodrama. Os sujeitos da pesquisa foram professoras das séries iniciais do ensino fundamental de uma escola pública do Distrito Federal. Realizou-se o curso O lugar do infantil na memória educativa: implicação e reflexão em escrita e ação, em parceria com a Escola de Aperfeiçoamento dos Profissionais de Educação (EAPE), a partir do qual os dados foram coletados, analisados e interpretados com base na análise de conteúdo de Bardin (2011). Emergiram três categorias: laços e suas vicissitudes; processos identificatórios e transferenciais; e mal-estar do professor: da inscrição à elaboração. Considerando que a pesquisa teve cunho reflexivo, as ações que dela decorreram podem contribuir na prática de formação dos professores buscando, por meio da psicanálise, suscitar novas posturas em sala de aula com repercussões no ensinar e aprender, tornando-se um espaço privilegiado para a compreensão e aquisição de outro olhar para o processo educativo.

Palavras-chave: infantil, subjetividade, psicanálise, memória educativa, sociopsicodrama. 


\begin{abstract}
This work is based on the question of how the teacher understands the meaning of the child dimension in its subjective constitution and the possible repercussions on the teaching profession in light of the psychoanalytic contribution. Specific objectives include: recognizing that the dimension of childlike occupies a central place in the constitution of teacher subjectivity with repercussions on the educational process in the classroom; to identify possible implications of the teacher's performance in the initial series of elementary education in the constitution of the child's subjectivity; and the articulation of educational and sociopsicodrama memory. The research was carried out in the qualitative methodological approach through the device of educational memory, records in the field diary, semi-structured interviews and workshops using the sociopsicodrama. The subjects of the research were primary school teachers of a public school in the Distrito Federal. The course: The place of the children in educational memory: implication and reflection in writing and action, in partnership with the Escola de Aperfeiçoamento dos Profissionais de Educação (EAPE), from which the data were collected, analyzed and interpreted on the basis of In the content analysis of Bardin (2011). Three categories emerged: ties and their vicissitudes; identification and transference processes; and teacher malaise: from inscription to elaboration. Considering that the research had a reflective character, the actions that took place could contribute to the training of teachers, seeking, through psychoanalysis, to raise new postures in the classroom with repercussions in teaching and learning, becoming a privileged space for the understanding and acquiring another look at the educational process.
\end{abstract}

Keywords: childlike, subjectivity, psychoanalysis, educational memory, sociopsicodrama. 


\section{LISTA DE QUADROS}

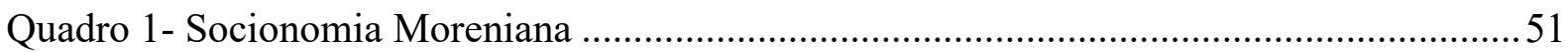

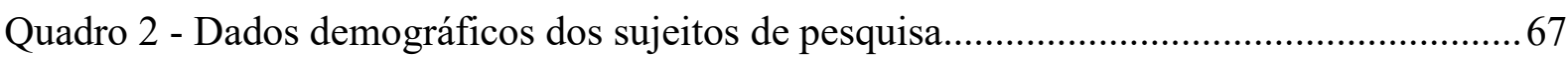

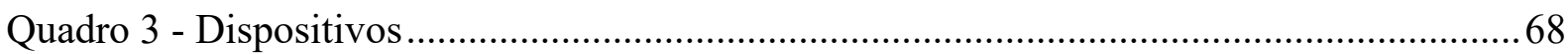

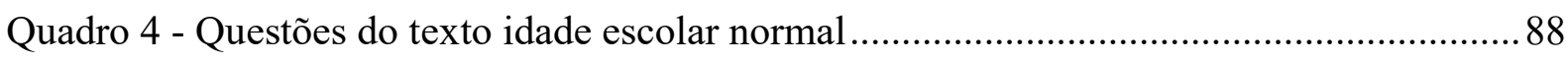

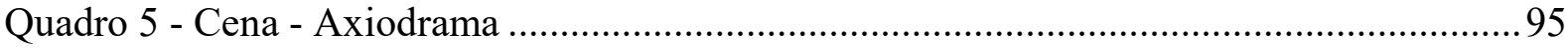




\section{LISTA DE FIGURAS}

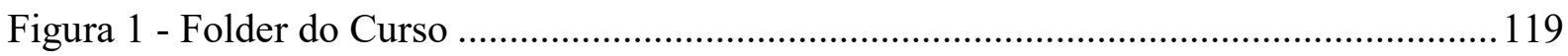

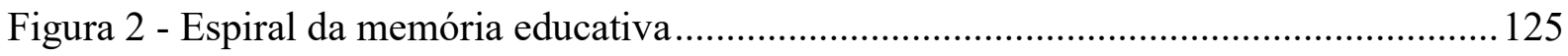




\section{SUMÁRIO}

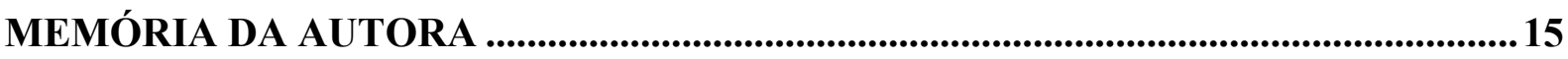

INTRODUÇÃ

PROBLEMA DE PESQUISA .........................................................................................27

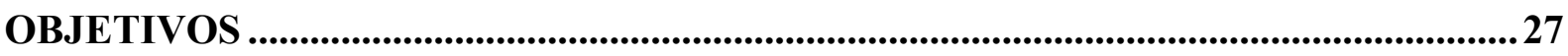

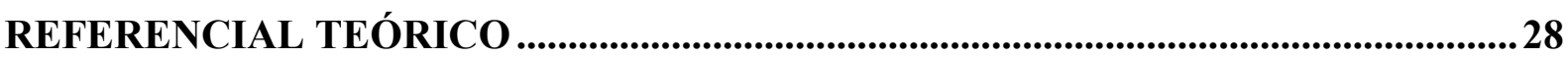

CAPÍTULO 1- A CONSTITUIÇÃO DO INFANTIL .......................................................28

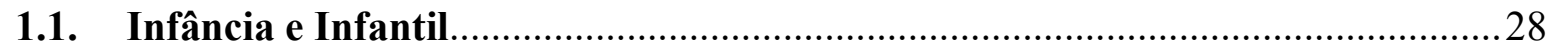

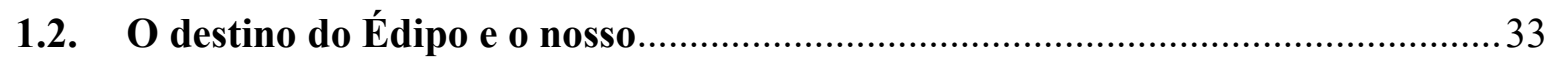

1.3. Leonardo Da Vinci e uma lembrança de sua infância.............................................37

CAPÍTULO 2 - A QUESTÃO DA ESCRITA NA CONSTITUIÇÃO DO SUJEITO..... 42

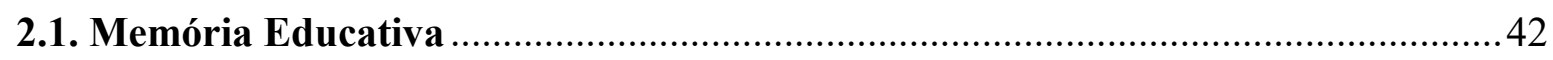

2.2. A dimensão da ação na constituição do sujeito (sociopsicodrama) …………….....48

CAPÍTULO 3 - SUBJETIVIDADE (IM)POSSÍVEL.....................................................54

CAPÍTULO 4 - METODOLOGIA ..............................................................................59

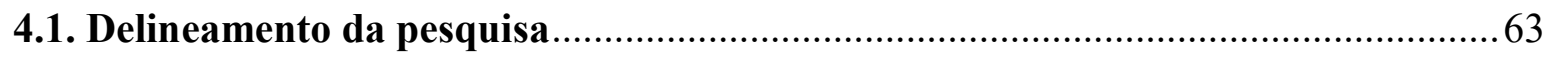

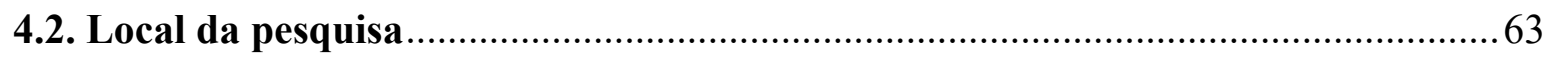

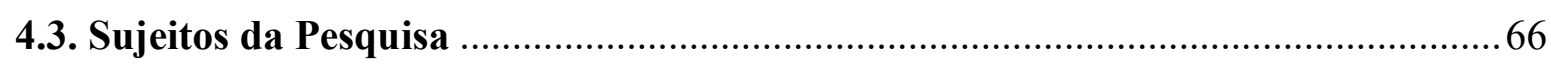

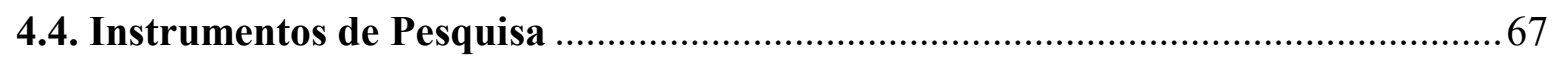

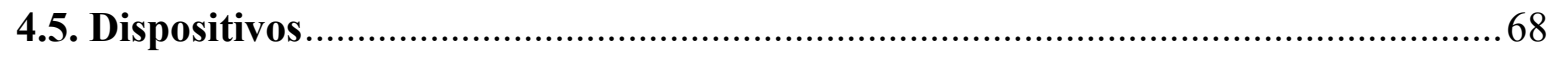

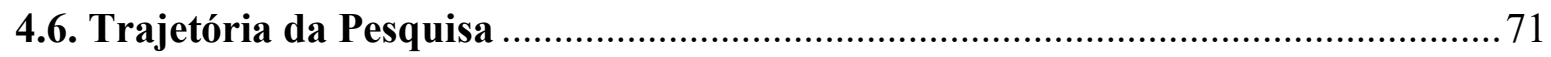

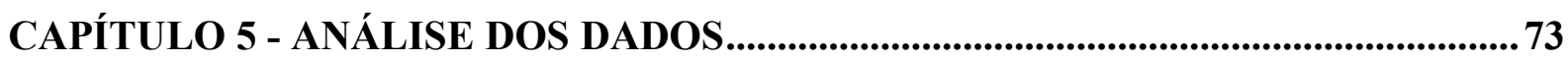

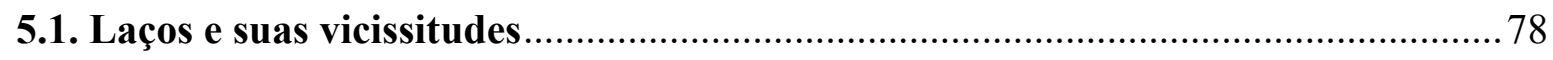

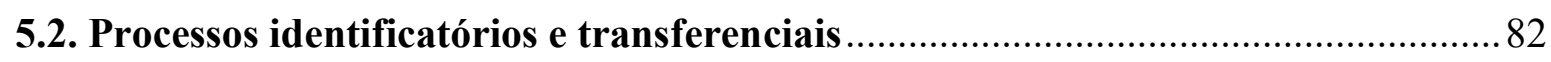

5.3. Mal-estar do professor: da inscrição à elaboração ................................................ 91

CONSIDERAÇÕES FINAIS..................................................................................................98

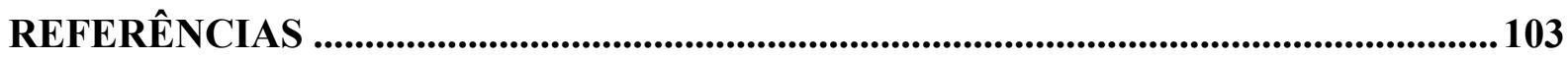

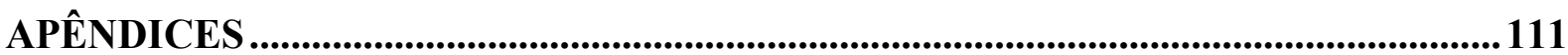

Apêndice A - Termo de consentimento livre e esclarecido das professoras .........................111

Apêndice B - Termo de consentimento livre e esclarecido da diretora.................................114

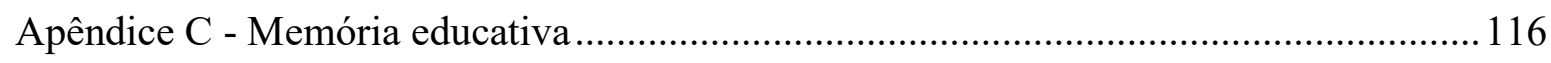

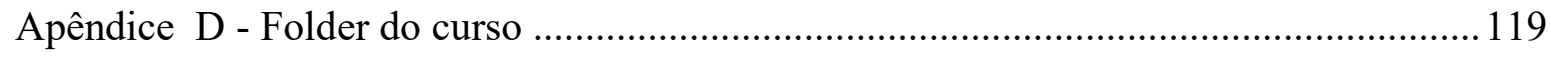

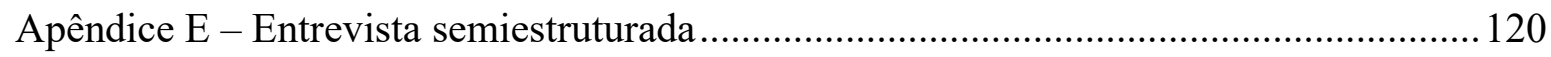




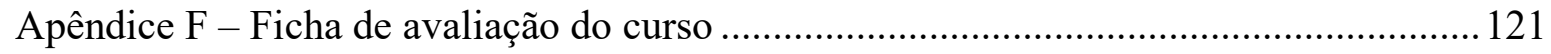

Apêndice G - Relatório dos encontros (diário de campo) ................................................ 122

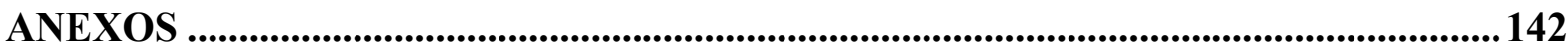

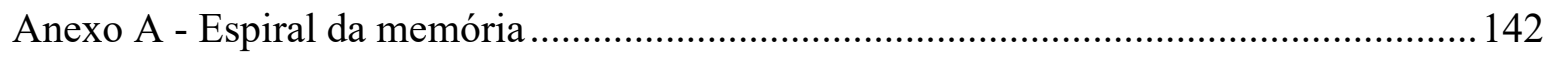

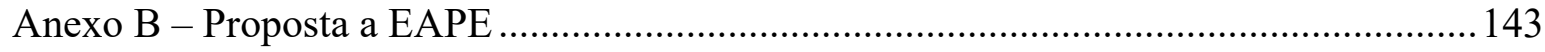




\section{MEMÓRIA DA AUTORA}

\section{UMA VIDA DE REALIZAÇÕES}

Fui muito desejada pelos meus pais. Minha mãe sempre gostou de escrever e registrar momentos. Neles pude encontrar escritos desde o encontro da minha mãe com meu pai. A união se deu em 1973 e, dois anos depois, nasci em Brasília. Minha descendência é mineira e goiana. Em fotos, é visível a paixão e alegria dos meus pais em estar comigo. Da família paterna recebi muitos cuidados devido ao fato de ter nascido quando meus primos eram adolescentes. Da materna vim ao mundo no mesmo ano de alguns primos proporcionando muitas vivências e encontros na casa da minha avó praticamente todos os fins de semana.

A origem do meu nome remete a leitura feita por minha mãe. Em um romance escrito em inglês (ela era professora de um curso de inglês), uma personagem era admirável e com características bem marcantes (meiga, atenciosa, prestativa). A identificação foi tanta que ela sugeriu que meu nome fosse KATHLYN. Na época, o cartório era impedido de registrar nome estrangeiro e só poderiam ser utilizadas letras do nosso alfabeto. Meu pai e o escrivão criaram um nome parecido e aceitável KATILEN. Um nome diferente.

No ano em que nasci, meu pai comprou uma fazenda e realizou seu maior desejo. Desde bebê, eu ia frequentemente à fazenda, criando laços significativos com o jeito simples e humilde de viver. Toda minha família frequentava e sempre nos feriados e férias para lá ia com meus primos, primas e vizinhos. Brincava sem parar. Minha infância e adolescência ocorreram na fazenda.

Meu irmão nasceu quando eu tinha dois anos e cinco meses. Recordo-me de sentir ciúme, mas querer cuidar dele. Quando minha irmã nasceu, eu já tinha cinco anos e foi minha realização, minha "boneca" de verdade. Passava o dia cuidando dela. 
Minha vida escolar iniciou-se aos cinco anos em escola católica (1980). Algumas vizinhas estudavam ali e íamos juntas, revezando a carona. Minha mãe, sempre cuidadosa com meu material, uniforme, tudo bordado à mão. Sentia forte desejo de ir para a aula e não dei trabalho para me adaptar. As professoras e a diretora eram religiosas, e desde nova, fui inserida na religião dos meus pais.

Lembro-me de alguns fatos ocorridos na escola, festa das bonecas, brincadeiras no parque de areia, trabalhos de desenho e pintura feitos na folha em branco. Gostava de brincar de ser professora, ficava na sala com algumas coleguinhas dando aula e fingindo ser a mestra. Minha realização era desenhar no quadro e escrever as primeiras letras.

As irmãs passavam um ar de divindade, como deusas. Sempre admirei. Minha alegria era dar a mão à irmã que ficava nos recepcionando no pátio da entrada. Foram muitas marcas de afeto.

Na primeira série (alfabetização), meus pais me matricularam em uma escola pública localizada perto de casa e muito elogiada. Como comecei a ler rápido, a professora sempre chamava alguém da direção para que eu pudesse ler algum texto. Um dia, minha mãe passava em frente à sala e foi abordada pela professora, que pediu para eu ler um texto (que falava de um sapo). Grande foi a emoção. A professora sentia grande orgulho de cada aluno que começava a ler e escrever. E isso me fascinava, a responsabilidade de ensinar, transmitir conhecimentos. Em casa dava aula para os meus irmãos e para os vizinhos. Sentia-me a própria professora.

Meus presentes sempre remetiam a material escolar e bonecas: quadro de giz, mesinha, cadeira, apagador, livrinhos de histórias e cadernos para anotações.

$\mathrm{Na}$ terceira série, tive uma professora que foi minha referência. Nascemos no mesmo dia e, nesse ano, meus pais comemoraram meu aniversário e o dela na sala. Foi uma grande festa. 
Minha mãe tornou-se sua amiga para além da escola e até hoje eu a encontro na igreja que frequento.

Minha mãe era amiga da escola, impressionante como era presente e participava de tudo. Como possuía confecção promovia desfiles no colégio para ajudar nas festas. Em um ano, ganhei o título de Rainha da Pipoca na Festa Junina. Foram muitas rifas que vendemos em vários lugares. Mobilizamos muita gente. Senti-me importante e feliz.

Tive a feliz oportunidade de conviver com minha avó materna desde o meu nascimento. Seus ensinamentos e conversas me marcaram profundamente. Era exemplo de bondade e transbordava amor. Tínhamos afinidade sem igual e me alegrava sentir o seu orgulho nas minhas realizações. Durante alguns anos ela morou em nossa casa.

Minha infância foi regada de fantasias e, como eu e minhas primas sonhávamos ser paquitas (assistentes de palco do programa da Xuxa), minha mãe e tias se reuniram e montaram um grupo cover. Ensaiávamos nos fins de semana e começaram a surgir os primeiros shows e apresentações. Achava o máximo as crianças pedirem beijo, abraço e até autógrafo! Sentia que fazer o bem e os outros felizes era realização sem igual. Passamos anos nos apresentando, assistindo os vídeos e aprendendo as coreografias. As roupas eram confeccionadas pelas mães. Cada uma tinha sua poupança para guardar o "cachê".

Estudei até a oitava série na mesma escola, fiz muitos amigos os quais encontro até hoje, fazíamos trabalhos em grupo e nos reuníamos nas casas para fazê-los e estudar para as provas. Tive uma professora de matemática cujo filho tinha deficiência física causada pela paralisia infantil. Colega de sala, tinha muita paciência com ele, que me chamava para fazer as tarefas em sua casa para que lhe desse atenção. Ela me ajudava nas tarefas e passava mais exercícios de matemática. Hoje percebo claramente o quanto essa convivência foi importante para mim.

Ao término da oitava série, não tive dúvida, queria ser professora. Eram muitos modelos na família e isso também me inspirou. Fiz a seleção da Escola Normal de Brasília e passei bem 
colocada. Comecei a minha realização e sonho de criança. Foram momentos mágicos, passava o dia na escola, que era de período integral. Recebi muitos ensinamentos. Tenho até hoje meu caderno de planejamentos, estágio e os livros de caligrafia. Alguns professores foram marcantes como os de didática e filosofia.

No mesmo ano de inserção no curso normal em 1988, tornei-me catequista (após a crisma), começando com os pequeninos e passando para as turmas de primeira comunhão, realizando-me. Essa paixão me move até hoje. A vivência religiosa em minha vida é muito forte e marcante (por alguns momentos tive o desejo de ser freira). Mas o desejo de casar e ter filhos falou mais alto. Com 17 anos, conheci meu marido em um encontro da igreja. Namoramos seis anos e depois de um ano de noivado nos casamos.

No último ano do curso normal fiz estágio em uma escola pública da Asa Sul e amava estar em sala. Lembro do cheiro de álcool das folhas mimeografadas no "cachacinha". Um dia a professora titular adoeceu e eu assumi a turma sozinha, sendo um marco grande e a certeza de que estava no caminho certo. Após alguns dias a diretora procurou-me para dizer que os alunos queriam que eu ficasse e algumas mães foram à escola manifestar essa vontade. Fizeram bilhetinhos. Fiquei muito feliz. Até hoje guardo o meu caderno de planos de aula e os bilhetinhos dessa turma.

Antes mesmo de terminar o curso normal, passei no vestibular de Pedagogia, no UniCeub, na inscrição, fiquei em dúvida entre pedagogia e psicologia. Mas a área da educação fez mais sentido naquele momento.

Iniciei a graduação e deixei o currículo em vários estabelecimentos. Para minha surpresa, fui chamada para dar aula no jardim I em uma escola particular tradicional no bairro onde eu morava e moro até hoje. Com 17 anos iniciei a melhor aventura da minha vida, cheia de expectativas, anseios e marcada pela vontade de fazer o melhor. Dediquei-me muito. Ganhei título de professora destaque e, após dois anos de sala de aula, fui convidada a ser coordenadora 
pedagógica. Algumas colegas de trabalho se assustaram já que eu tinha pouco tempo na escola e outras eram mais experientes. Assumi como um desafio e, aos poucos, consegui conquistar a confiança e o apoio de todos.

Ao término da graduação, especializei-me em orientação educacional, professora de didática e psicologia da educação. Ao concluir, entrei na pós-graduação em psicopedagogia, na Universidade Católica, foi a primeira turma em Brasília (1996). Passei em 1996 no concurso da Secretaria de Estado de Educação (SEEDF) para o cargo de orientadora educacional e ingressei no ano seguinte. Durante o dia trabalhava na escola particular como coordenadora, e à noite, assumi uma escola no Paranoá. Minha vida era trabalhar. Minha família sentia muito orgulho de mim. Meu pai contava a todos com muita satisfação. Esse incentivo motivava-me a continuar.

Por indicação, recebi um convite muito especial para acompanhar um aluno com síndrome de Down, dando reforço e estimulando com jogos o seu desenvolvimento. Como fazia psicopedagogia, pude aplicar alguns conhecimentos fazendo um estudo de caso. Nossa proximidade e identificação foram muito importantes e saber que fiz parte do seu crescimento é maravilhoso. Atualmente ele é fotógrafo profissional e já escreveu dois livros. Temos contato até hoje. Ele me constituiu como educadora.

Com apenas um ano de trabalho na SEEDF, fui convidada a ser assistente pedagógico (cargo comissionado). Mais uma vez um grande desafio e realização. Precisei sair da escola particular e submeter-me ao diretor da regional do Paranoá por estar em estágio probatório, o que não era usual. Participei de uma entrevista e assinei um termo de compromisso. Nesse processo fiquei noiva, tornei-me ministra extraordinária da sagrada comunhão, sendo para mim a realização suprema e mais marcante da minha vida religiosa. Foram 10 anos de vivência cristã fundante. 
Na seleção de aluno especial para o mestrado na UnB escolhi duas disciplinas. Uma educação e psicanálise. A outra, educação de jovens e adultos - EJA. Passei nas duas seleções e começou a realização de mais um sonho. Sonho duplicado por estar grávida de um menino, sentia-me plena e feliz. Na disciplina da psicanálise, fui surpreendida com uma grande identificação e desejo de trilhar o caminho traçado por Freud como linha de pesquisa. O conteúdo da disciplina reportava-me ao meu cotidiano escolar e familiar. Conquistou-me. Tamanha foi minha identificação e admiração que planejei fazer mestrado sob a orientação da professora Inês Maria. Saía das aulas maravilhada.

Com a chegada do primeiro filho em 2003, mudei de escola passando a trabalhar perto de casa como orientadora educacional com alunos do ensino médio e séries finais do ensino fundamental. Posterguei o desejo do mestrado fazendo a opção de ter os filhos primeiro. Em 2005, veio o segundo filho. A comunidade atendida pela escola demandava-me muita dedicação, passando a envolver-me com situações de risco e com grande carga emocional. Comecei a trabalhar em parceria com o Centro de Referência da Assistência Social-CRAS, Conselho Tutelar, Centro de Integração Empresa Escola-CIEE, entre outros. Foram 14 anos de muitas realizações em todos os âmbitos (formaturas, organização de semana das profissões, criação do grêmio estudantil que continua forte e atuante até hoje, pedidos de apadrinhamentos presenteando-me com seis afilhados).

Encontro ex-alunos que hoje são professores, pedagogos em potencial, que me procuram para dividir experiências e anseios. Alguns fizeram estágio na escola, entrevistas e trabalhos. É gratificante. Uma dessas alunas marcou-me muito. Ao dividir comigo a suspeita de uma gravidez, acompanhei desde o resultado positivo, preparação dos pais para receber a notícia e a força necessária para que não abortasse a criança como o namorado havia sugerido e não abandonasse os estudos. Nosso envolvimento foi tanto que, ao descobrir que o filho era menina, 
decidiu batizá-la com meu nome. Nos encontramos até hoje. E vários foram os casos de superação de que pude fazer parte.

No período da infância dos meus dois filhos, continuei fazendo cursos, especializações e, no meu íntimo, vinha o desejo do mestrado, sempre lia o edital. Tive duas perdas muito grandes nessa espera. Com oito semanas de gestação, perdi meu terceiro filho, e meu pai faleceu. O sentido da vida mudou, a fé ajudou a me sustentar.

Esperei 12 anos para mais uma realização. No mesmo ano da seleção do mestrado aceitei o convite para dar aulas em uma faculdade de pedagogia. Fiz parte de bancas de TCC dandome um aporte acadêmico e a vontade e necessidade de me aperfeiçoar cada vez mais. Voltar a estudar e construir meu conhecimento é fantástico e remete-me à infância de estudos e empenho, momentos marcantes que me constituem até hoje.

A entrada para o mestrado foi o ponto mais alto, principalmente por ser sob a orientação da professora que sempre admirei e guardei no meu coração por mais de uma década. Nosso reencontro foi regado de recordações, "não por acaso nos encontramos" é nossa certeza. Realiza-me estar neste desafio com uma orientadora que tem sensibilidade e um extraordinário aporte acadêmico. Cada encontro é uma aula de cultura e conhecimentos. Ganhei um coorientador fantástico, que tem nos mostrado diversas possibilidades com muita propriedade e sabedoria.

Enfim, trabalhar com as memórias é reconhecer seus laços com a história de vida do professor, pois alguma coisa do sujeito inconsciente comparece, assim como as vicissitudes enfrentadas nas complexas relações entre objetividade e subjetividade. Faz sentido crer que a maneira como cada um de nós ensina está diretamente ligada ao que somos como sujeitos. Em toda sua complexidade, a memória guarda consigo a capacidade de resgatar o tempo-história como inscrito nas entranhas do atual ainda que haja diferenciação entre o vivido e o que se inscreve no psiquismo, entre a infância e sua interiorização (ALMEIDA,2006). 
Foram muitos encontros felizes que a vida me proporcionou e continua a proporcionar. Sem dúvidas uma vida regada de realizações. Meus pais e minha família fazem parte dessa história por acreditarem em mim e por serem meu porto seguro e referência. Minha gratidão eterna. 


\section{INTRODUÇÃO}

Atuando há vinte 24 anos na área da educação como professora de séries iniciais, orientadora educacional e professora do curso de pedagogia, percebo cada vez mais a importância do infantil na constituição da subjetividade. Com ela, compreende-se melhor as demandas relacionadas com indisciplina, problemas de ensino-aprendizagem, dificuldades no universo escolar e na relação professor-aluno.

Em meu percurso profissional como orientadora educacional, percebo o quanto o aluno, muitas vezes, não é respeitado em sua singularidade, história de vida, memória afetiva, dificuldades, enfim, em seus valores e atitudes únicas.

A "criança" no sentido freudiano habita no adulto também. Somente alguém que possa sondar a mente das crianças será capaz de educá-las, e nós, pessoas adultas, não podemos entendê-las as crianças porque não mais entendemos a nossa própria infância (FREUD,1912).

Nos escritos freudianos, o conceito de infantil coloca-se como campo de ligação. Nele confluem a estrutura como campo de possibilidades definido a partir de uma história, recuperada a partir do não-tempo do inconsciente. Além de seu caráter determinante na constituição psíquica, é, também, o mais antigo, o mais precoce, tanto no sentido daquilo que é mais remoto, quanto no sentido daquilo que está em conexão com modos arcaicos do funcionamento psíquico.

Blanchard-Laville (2005) aponta que o laço didático é tecido de mal-entendidos de uma parte e de outra. Esses mal-entendidos existem sem que o professor tome conhecimento deles no plano psíquico, em especial no que diz respeito à transmissão de saber e às modalidades de relações com os alunos.

No seus escritos, Almeida e Bareicha (2015) apontam que as produções são sempre singulares porque trazem a marca da incompletude, da impossibilidade de delimitar o que é da 
ordem do consciente e/ ou do inconsciente. Talvez seja por isso que, em nossos esforços para compreender a constituição da subjetividade do professor e o lugar do infantil nesse processo, devemos reconhecer que sempre vamos nos deparar com buracos, lapsos ou esquecimentos que teimam em aparecer, pois a escrita transporta detritos que atravessam a narrativa.

Pensando no conceito e importância do infantil bem como nas contribuições freudianas no processo, surge a concepção da memória como um dispositivo de pesquisa para enunciação do sujeito que comparece evidenciando o lugar do infantil na constituição da subjetividade. Para Tanis (1995), abordar a questão da memória é de grande atualidade para compreender a natureza do infantil.

O próprio Freud sustentou que toda memória é impregnada pela subjetividade do sujeito como as lembranças, mesmo as que emergem surpreendentemente do decorrer de uma análise. Tanis (1995) reforça que tempo e memória são elementos constitutivos da experiência subjetiva com os quais nos defrontamos em nossa existência. A memória, em toda sua complexidade, guarda consigo a capacidade de resgatar o tempo da história. Não como um tempo passado, mas como um tempo inscrito nas entranhas do atual.

Devido à importância da memória, que recupera a história, em que a inscrição pode ser um fato, o sujeito se instaura na medida em que dá conta de uma história passada, constituindose e recuperando as relações originárias (UR, ou seja, origem). Depara-se com o lugar do infantil. Tanis (1995) reconhece a dimensão histórico- infantil como argamassa que permite a liga entre os tijolos que constroem o edifício teórico legado por Freud, ainda que a psicanálise não deva ser confundida com a busca histórica do passado como adverte Kaufmann (1996), para não cair no historicismo e o analista ocupar o lugar de historiador, afinal a psicanálise é pura construção elaborada no espaço analítico e o que ela produz é uma história reescrita para um devir, uma história renovada pelo processo transferencial da análise. 
Complementarmente lembramos que Moreno em seu livro Fundamentos do Psicodrama (1983, p.207), reforça a ideia de que o psicodrama explora a verdade por meio de métodos dramáticos. É a terapia grupal profunda. Começa onde a psicoterapia de grupo acaba e a amplia, a fim de torná-la mais eficiente. O objetivo expresso da terapia de grupo é o de funcionar como sociedade em miniatura para seus membros, de modo que estes possam adaptar-se mais harmoniosamente do que até então. Levando esse objetivo a sério outros métodos devem ser acrescentados, além da conversação, da entrevista ou da análise, a fim de que o mesmo, uma catarse da integração possa ser cumprido.

À medida que o professor se coloca como alguém que não é o dono do saber, nem de todas as certezas absolutas, o educador está identificado na relação pedagógica com o aluno. A aquisição do conhecimento depende estreitamente da relação do aluno com seus professores. Os educadores investidos da relação afetiva primitivamente dirigida aos pais se beneficiarão da influência que este último exercia sobre a criança e poderão desse modo contribuir para a formação do ego ideal da criança (FREUD,1976).

Alguém que escolheu ser professor para Voltolini (2011), não chegou a essa decisão por acaso, mesmo se acredita ter sua opção sem muita reflexão, já que contam numa escolha profissional não só motivações conscientes, mas também fantasias inconscientes. Pesará, certamente, seja na decisão, seja no estilo que adotará na prática docente, a influência recebida dos vários professores que teve.

Em infância e ilusão (psico)pedagógica, Lajonquière (1999), comenta que educar é transmitir marcas simbólicas que possibilitem à criança conquistar para si um lugar numa história, mais ou menos familiar, e, dessa forma, poder se lançar às empresas do desejo.

O encontro entre o que foi ensinado e a subjetividade de cada um é que possibilita a aprendizagem, gerando novos conhecimentos. Dessa forma, é clara a relação do sujeito na aprendizagem com sua subjetividade e vivências, visto o quanto é importante o educador se 
inserir no processo, vislumbrando o infantil que o constitui. Assim, por meio do aporte psicanalítico, reconhecer o quanto é significativo na interface da educação.

Guimarães (2007) diz que o enlace entre a psicanálise e a educação se faz no dia a dia, possibilitando uma forma diferenciada de posicionamento do educador diante das questões que se apresentam no processo de ensinar e aprender. Lajonquière (2010) pontua que a psicanálise "aplicada" à educação consiste em analisar e dissolver as ilusões tecnocientificistas que imperam no campo educativo com vistas à educação para a realidade impossível do desejo.

A constituição do saber perpassa pela subjetividade, sendo assim, a práxis educativa com o processo pedagógico tem possibilidade de se concretizar nas relações cotidianas de ensino e aprendizagem. Essas relações e a realidade psíquica decorre da hipótese freudiana da existência de um inconsciente que divide o sujeito, permeada pela afetividade constitutiva desde a infância. Transformar a relação com o infantil não significa sua eliminação, mas permitir uma reorganização de forças para que o novo possa advir. Percebemos o efeito com relação o sujeito na aprendizagem com sua subjetividade e vivências e o quanto é importante o educador se reconhecer nesse processo, vislumbrando o infantil que o constituiu, refletindo sobre sua prática pedagógica podendo assim, contar com o aporte psicanalítico, que se faz como significativo na interface da educação.

Devido ao meu percurso acadêmico e profissional e à paixão pela temática, a escolha pelo aporte psicanalítico com utilização da memória educativa e sociopsicodrama apresentado ao longo do trabalho, foram fundantes na pesquisa para anunciar e justificar a importância da temática. 


\section{PROBLEMA DE PESQUISA}

A presente pesquisa tem como questionamento:

Como o professor compreende o significado da dimensão do infantil em sua constituição subjetiva e as possíveis repercussões no ofício docente?

\section{OBJETIVOS}

\section{Objetivo geral:}

Compreender a dimensão do infantil na constituição da subjetividade de professores à luz da teoria psicanalítica.

\section{Objetivos específicos:}

- Reconhecer que a dimensão do infantil ocupa lugar de centralidade na constituição da subjetividade docente com repercussões no processo educativo em sala de aula.

- Identificar possíveis implicações da atuação do professor de educação das séries iniciais do Ensino Fundamental na constituição da subjetividade infantil.

- Articular o dispositivo da memória educativa em escrita e ação através do sociopsicodrama como alternativa metodológica de pesquisa. 


\section{REFERENCIAL TEÓRICO \\ CAPÍTULO 1- A CONSTITUIÇÃO DO INFANTIL}

\subsection{Infância e Infantil}

O conceito de infância e infantil, na psicanálise, não são sinônimos. A infância diz respeito à idade cronológica referente a um tempo da realidade histórica. O infantil é atemporal e nos constitui, de acordo com Zavaroni, Viana e Celes (2007). Sendo assim, o infantil assume seu caráter mais indelével ao se mostrar como uma vocação estrutural do sujeito e do inconsciente, ultrapassando as barreiras da cronologia. A oscilação com relação à compreensão da infầncia e do infantil trouxe como consequência uma revolução dentro da própria psicanálise, através da qual nova leitura se processa sobre o sujeito, o sintoma e o inconsciente (BIRMAN,1997).

No "Projeto para uma psicologia científica", Freud (1950[1895]/1980) atribui às experiências infantis valor determinante e fundante do psiquismo. Ele estabelece o desamparo infantil e a busca de satisfação como elementos constituintes da subjetividade.

A teoria freudiana nos permite afirmar, portanto, que o sujeito é infantil por vocação e não por contingências em seu desenvolvimento cronológico-evolutivo. Contudo, se em Freud, o infantil não chegou a ter lugar destacável como conceito, a partir do ensino de Lacan, ele recebe importância e especificidade conceitual, o que acaba por articulá-lo a outros conceitos não menos cruciais, tais como o de sujeito e de estrutura (COSTA, 2015).

Através de suas elucidações sobre os processos estruturantes do sujeito, Lacan (1985) permite empreender uma distinção necessária entre os conceitos de infância e infantil. No universo cotidiano, os termos infância e criança refletem concepção comum à psicologia desenvolvimentista, na qual o organismo e o cognitivismo se desenvolvem desde uma 
imaturidade até uma maturação (SAURET,1998). Porém Costa, no artigo “ A Criança, o adulto e o infantil na psicanálise", afirma que a lógica que se aplica a esse tipo de desenvolvimento cognitivo não é a mesma que pode explicar a categoria de sujeito na psicanálise. O sujeito é conceituação da psicanálise que aponta para o funcionamento de um discurso do inconsciente, que, porém não se desenvolve porque se constitui num processo, cujo tempo lógico é singular. É nesse processo que o infantil deve ser compreendido em sua relação com o conceito de estrutura.

Lajonquière comenta em seu livro "Figuras do infantil: a psicanálise na vida cotidiana com as crianças" (2010) que, certa vez, em 2003, ministrando um seminário na Universidade de Brasília a convite da professora Inês Maria Pires de Almeida, alguém da plateia comentou que havia formulado a seguinte pergunta a uma criança: "O que é a infância?” A criança, de uns 10 anos, respondeu: “A infância é aquilo do qual os adultos falam quando lembram que foram crianças" (LAJONQUIÈRE,2010, p.201).

O desafio de investigar o conceito de infância para as crianças também me fez perguntar aos meus filhos. O que é a infância? Como resposta encontrei: "É tudo que a gente faz antes de ser adolescente”, João Marcelo (12 anos). E também: “É a época que eu estou”, Rafael (10 anos). Nesse sentido, percebemos o quanto a infância remete aos tempos de criança, experiências, anseios e realizações que marcam e constituem a subjetividade.

No XI Colóquio Internacional do Lepsi (Laboratório de Pesquisas e Estudos Psicanalíticos e Educacionais sobre a Infância), II Congresso Brasileiro da Red INFEIES (Brasil e América Latina), VI Congresso da RUEPSY (Brasil e Europa) e II Simpósio de Psicanálise e Educação de Minas. No Colóquio Internacional realizado em Belo Horizonte em setembro de 2016, cujo tema Os sintomas na educação de hoje: o que fazemos com "isso"? Leny Mrech, em apresentação intitulada “A infância, o infantil, a criança e a psicanálise”, trouxe pontos muito pertinentes tendo em vista que, na Idade Média, a infância e a criança ocupavam um lugar 
secundário. A criança era vista como um pequeno adulto, tornando a própria concepção de infância praticamente inexistente. $\mathrm{O}$ conceito de infância surgiu em um período relativamente recente na história da humanidade. Pode-se mesmo dizer que, embora sempre tivesse existido a criança, o mesmo não ocorreu com a concepção de infância. E ela, tal como a conhecemos, é uma construção social.

A matéria-prima para a produção da infância é o infans: cria sapiens, privada de fala tanto humanamente indeterminada quanto impossibilitada de ser animal. Em suma, infans é o nome de uma indeterminação biológica muda (LAJONQUIÈRE,2010).

Fundamentado em determinantes da infância, Lajonquière (2010) aponta que a demanda educativa produz uma infância trifásica: 1) a infância como tempo de espera; 2) a infância como um conjunto de operações linguageiras ou realidade psíquica; 3) o real da infância ou suplemento infantil que, cindindo a realidade psíquica produzida, abre o conjunto de operações à sobredeterminação. Esse resto infantil não cessa de não se inscrever e, portanto, relança sobre si mesmo o processo instituinte de uma infância singular numa história.

O autor traz ainda a subjetividade não como substância em desenvolvimento nem enteléquia em vias de encarnação. Ela é um conjunto extensível de operações de uma linguagem singular que comporta os registros real, simbólico e imaginário, precipitado na indeterminação carnal do sapiens. O nó vazio dessas operações é o sujeito do desejo, reduzido assim ao sutil estofo de operador funcional.

Nos "Extratos dos documentos dirigidos a Fliess" (Freud, 1950 \{1892-1899\} 1980), já havia a compreensão de que, na reconstrução dos primeiros anos de vida feita em análise estão contempladas tanto as recordações de infância proferidas ao analista como a infância esquecida. Não era apenas aquilo que o paciente recordava que Freud considerava relevante na compreensão dos sintomas, mas também e, sobretudo, a infância que ficou esquecida. 
Em vários escritos freudianos são recorrentes cenas, lembranças e relatos que remetem à infância, aos primeiros anos de vida. Tanis (1995) corrobora quando aponta que o infantil na psicanálise mantém posição privilegiada não apenas pela implicação na constituição do sujeito, mas também por ser constituinte do próprio modo de funcionamento do inconsciente.

O campo do infantil começa a se configurar em Freud a partir de uma interrogação etiológica sobre a neurose, que, segundo Laplanche e Pontalis (2001), é afecção psicogênica em que os sintomas são a expressão simbólica de um conflito psíquico que tem raízes na história infantil do sujeito e constitui compromissos entre o desejo e a defesa. É nesse contexto que o infantil se relaciona principalmente com a dimensão traumática das experiências da criança ou do adolescente.

Em relação à noção do infantil, Pontalis afirma (Nouvelle revue de psychanalyse, 1979): “Acaso a psicanálise não é, em seu próprio princípio, tanto na teoria quanto na prática, inteiramente movida pela crença, sempre confirmada, de que aquilo que chamamos "adulto"aliás com hesitação cada vez maior- é modelado de uma ponta a outra pelos conflitos, traumas, fantasias e desejos da criança? "Nos escritos de Lacan, o infantil será aquilo do qual a criança e o adulto não conseguem colocar em palavras nem se afastar.

A especificidade conceitual que contorna a ideia de infância e de infantil na psicanálise sempre esteve, de algum modo, presente nos trabalhos de Freud, delimitando, determinando e configurando diversas construções teóricas (ZAVARONI, VIANA e CELES, 2007). Freud sublinha um infantil que não se "desfaz" no adulto, mas permanece determinando aquilo que o reconstrói. Dar a devida importância ao infantil através de conceitos e princípios que constroem a nossa subjetividade proporciona o discernimento de que somos únicos em nossa constituição.

Desse modo, o infantil é o que podemos conceitualmente extrair da divisão entre pulsão e linguagem, oriunda do processo em que a necessidade é transportada para o campo da demanda. O infantil é o que está envolvido na condição faltosa que move a constituição do 
sujeito (SAURET,1998). Freud identificou essa falta-a-ser à essência do ser humano e chamoua de "desejo".

Não foi por acaso que Freud recolheu o infantil que os tempos modernos, embora insistissem, não podiam simbolizar sem resto. Esse gesto deu lugar à invenção da psicanálise. Esse resto, o infantil, permanece no adulto e faz deste um simples velho (LAJONQUIÈRE, 2010).

Kupfer (2007) remete à noção do infantil, afirmando que Freud explodiu os limites do conceito: tratamos da criança no adulto, ou seja, a criança persiste no adulto a ponto de fazê-lo adoecer. De outro lado, ele acabou por introduzir na criança algo que era antes prerrogativa do adulto: a sexualidade. E, como se isso não bastasse, a criança freudiana e, portanto, um sujeito que está a um inconsciente, não pode ser pensada como alguém cuja construção se inicia com o nascimento, do ponto de vista da constituição daquele sujeito. Sua história começa bem antes, começa com os avós. O que se passou com eles na constituição subjetiva inconsciente marcará também aquele sujeito, que já encontra ao nascer uma trama estendida sob ele. Trata-se, assim, de um conceito de infantil ampliado nas duas pontas. Por isso, ultrapassa nos limites a criança escolar.

$\mathrm{Na}$ fase adulta, o infantil continua ativo inconscientemente, influenciando na forma de amar, de se relacionar com o próximo, de lidar com o não afeto do outro e de trabalhar no exercício de sua profissão (ALMEIDA, KUPFER, 2011).

A dimensão do infantil está presente em nosso cotidiano, remetendo-nos a ser o que somos. Esse ser comparece em vários momentos, visto que está presente no inconsciente. Essa dimensão na vida é fundante de nossa constituição subjetiva e ocupa, neste trabalho, lugar de centralidade na pesquisa, análise e reflexões sobre a dimensão da constituição subjetiva do professor em escrita e ação. 


\subsection{O destino do Édipo e o nosso}

A partir do outro o sujeito vai se constituindo em meio a muitas operações estruturantes que a psicanálise chama de Complexo de Édipo.

Freud, em carta a Fliess de 15/10/1897, menciona pela primeira vez o mito de Édipo. Escreve na ocasião que tal descoberta se revelou na experiência de analisar os próprios produtos inconscientes. A tragédia de Sófocles, Édipo Rei, é tomada por Freud como um mito, mito edipiano, que se tornou central em sua doutrina. O mito é uma narrativa e tem caráter de ficção que mantém relação singular com a verdade. Nessa direção, Freud formula o complexo de Édipo para afirmar que o desejo inconsciente se determina no sujeito numa estrutura que é ternária. Uma rede complexa na qual o sujeito articula o seu desejo ao desejo do par parental (NEME,2008).

De acordo com Freud, capítulo I de Interpretação dos Sonhos (1900), Édipo Rei é capaz de comover um moderno leitor ou frequentador de teatro não menos poderosamente do que comoveu os gregos de antanho, a única explicação possível é que o efeito de tragédia grega não depende do conflito entre o destino e a vontade humana, mas da natureza peculiar da matéria, através da qual o conflito se revela. Deve existir uma voz, dentro de nós, que está preparada para reconhecer o poder coagente do destino no Édipo Rei. E existe realmente um motivo no Édipo Rei que explica o veredicto da voz íntima. Seu destino comove-nos, somente, porque poderia ter sido o nosso, porque o oráculo fez recair sobre nós, antes de nosso nascimento, a própria maldição que sobre ele tombara. Pode ser que estivéssemos todos destinados a dirigir nossos primeiros impulsos de ódio e resistência para nosso pai; nossos sonhos nos convencem de que estávamos. O Rei Édipo, que assassinou seu pai, Laio, e desposou sua mãe, Jocasta, é nem mais nem menos do que um desejo-efetivação: a efetivação do desejo de nossa infância. Mas nós, mais felizes do que ele, na medida em que não nos tornamos psiconeuróticos, logramos, desde a infância, afastar de nossa mãe os nossos impulsos sexuais e esquecer nosso 
ciúme em relação a nosso pai. Repugna-nos a pessoa em quem esse primitivo desejo de nossa infância se concretizou, com toda a força de repressão que esses desejos desencadearam na mente, desde a infância. À medida que o poeta vem trazendo a culpa de Édipo para a luz, por meio de sua investigação, força-nos a ganhar consciência de nossos próprios íntimos, nos quais os mesmos impulsos estão ainda latentes embora suprimidos. Como Édipo, vivemos na ignorância dos desejos que ofendem a moralidade, desejos que a natureza nos impôs e, depois de desvendados, talvez prefiramos desviar os olhares das cenas da infância.

Mullahy (1965) diz que Freud faz três observações factualmente a respeito do que ele denominou complexo de Édipo. Primeiro, a presença de impulsos sexuais nas crianças. Segundo, os vínculos pelos quais um filho está ligado aos pais não são, frequentemente, cerceados, quando, em resultado do crescimento, deveriam normalmente ser por força da crescente independência. Freud observou que a fixação irracional dos filhos aos pais se encontra em todas as neuroses, sendo uma das causas dos sintomas neuróticos e do caráter neurótico. Como Freud afirmou, o complexo de Édipo é o âmago de toda neurose. Terceiro, o conflito paifilho é característico das sociedades patriarcais, observando também como a fracassada rebelião do filho contra a autoridade do pai, e os temores do filho, em consequência da derrota, estabeleceram as bases para o processo de desenvolvimento neurótico. Freud interpretou a neurose e o complexo de Édipo como resultantes do conflito entre as paixões irracionais da criança e a "realidade" representada pelos pais e a sociedade.

É preciso estabelecer distinção entre as versões míticas sobre Édipo e o Complexo de Édipo teorizado por Freud. As versões mais antigas da lenda se referem a Édipo, pertencente à família dos Labdácidas, que reinou durante muito tempo em Tebas. A origem da maldição dos Labdácidas se liga a episódio na corte do rei Pélops. Laio, na época em que é hospedado por esse rei, apaixona-se por seu filho, o jovem Crisipo, que acaba se matando. Apolo, o oráculo de Delfos, indignado com Laio, lança-lhe a seguinte maldição: se Laio tiver um filho, ele vai matá- 
lo e causar a ruína dos Labdácidas. Laio se casa com Jocasta e eles têm um filho, Édipo. Para se livrar do rebento, ordena que lhe furem os pés com um gancho e os amarrem com uma correia, abandonando-o depois no monte Citerão. Na maioria das versões, Édipo acaba sendo adotado pelos reis de Corinto: Pólibo e Mérope (JORGE e FERREIRA, 2010).

"Cada ser humano que nasce deve enfrentar a tarefa de dominar o complexo de Édipo. Quem não pode resolvê-la cai nas neuroses". Com essa frase, retomamos que Freud sintetiza uma de suas teses centrais, segundo a qual o Édipo constitui o complexo nuclear das neuroses. A significação do Complexo de Édipo e de suas vicissitudes não pode ser de fato ignorada (Plastino, 2001). Por ser justamente o tempo em que o sujeito se estrutura mediante um ato de resposta. Diante da pulsão, o sujeito questiona o significante e assume ou a aceitação ou a recusa das marcas simbólicas vindas do Outro (COSTA, 2015).

A significação do complexo de Édipo foi discernida por Freud de maneira progressiva. “Desde sempre”, escreve na sua Apresentação autobiográfica (1925), "tinha me resultado enigmática a eleição pelo poeta desse tema cruel, bem como o efeito comovedor da figuração poética e, em geral, a essência da tragédia de destino. "Tudo isso, acrescenta, "ficou explicado ao entender que tinha sido apreendida com esse tema uma regularidade de acontecer anímico na sua plena significação afetiva" (PLASTINO, 2001).

Para Laplanche e Pontalis, o complexo remonta a um conjunto organizado de representações e recordações de forte valor afetivo, parcial ou totalmente inconscientes. Um complexo constitui-se a partir das relações interpessoais da história infantil. Pode estruturar todos os níveis psicológicos: emoções, atitudes, comportamentos adaptados. Segundo Freud, o apogeu do complexo de Édipo é vivido entre os três e os cinco anos, durante a fase fálica. O declínio marca a entrada no período de latência. É revivido na puberdade e é superado com maior ou menor êxito num tipo especial de escolha de objeto. Complexo de Édipo, portanto, 
designa uma estrutura fundamental das relações interpessoais, na estruturação da personalidade e na orientação do desejo humano modo como a pessoa encontra o seu lugar e se apropria dele.

Nessa perspectiva, não há sujeito sem Édipo e sem castração ou, em outras palavras, é a operatividade dos chamados por Freud Complexos de Édipo e de castração que recorta as fronteiras da subjetividade e instaura a dialética da demanda e do desejo no campo discursivo (LAJONQUIÈRE,2010).

Gomes (2009) sustenta que o processo de separação entre mãe e filho, anunciado pelo Complexo de Édipo por meio da castração, possibilita à criança deparar-se com a falta do Outro. Lembremos que estamos falando do Outro, com letra maiúscula, portanto não é um outro real, físico que se separa do bebê, mas uma instância simbólica, que antes preenchia um vazio e agora não mais. Nesse momento é que o desejo finalmente se institui e marca simbolicamente a constituição do sujeito do desejo.

Nina Saroldi, no prefácio do livro: “Complexo de Édipo. Freud e a multiplicidade edípica", traz que Katz (2009) remete às descobertas de Freud como constituintes das subjetividades e por isso não poderiam deixar de passar por ele mesmo na condição de sujeito submetido a uma análise. Na carta 71, de 15 de outubro de 1897, a seu amigo e confidente Wilhelm Fliess, comenta a interpretação de um sonho que tivera com a mãe e uma velha babá e afirma que, das dificuldades da análise, somente um pensamento despontou com clareza: a paixão pela mãe e o ciúme do pai. Freud reconheceu em si mesmo um sentimento que identificou como um universal do início da infância. E se refere, então, à força do mito de Édipo. Diz que a lenda grega abrange uma compulsão que toda pessoa reconhece porque lhe sente a presença dentro de si. Revela ainda que cada pessoa da plateia foi um dia, real ou fantasiosamente, um Édipo e, por isso, sempre se deixa tocar pela atualização dos sentimentos inconscientes que a tragédia promove. 
Se a expressão, literalmente descrita por Freud como Complexo de Édipo, só aparece como tal em 1910, ele já havia invocado tal questão anteriormente, para pensar a respeito de sentimentos ou afetos que seriam do indivíduo isoladamente (no caso, dele mesmo, do próprio Freud), mas que se manifestariam simultaneamente também no que conhecemos como "humano" de modo generalizado. Ou, ainda, como sinônimo de psiquismo inconsciente ou aparelho psíquico fundado teoricamente (KATZ,2009, p.21).

Freud, com a descoberta do inconsciente, denominado por ele mesmo de a "outra cena", nos remete à verdade de que não somos senhores em nossa própria morada nem temos total controle de nós mesmos, muito menos de quando e quais circunstâncias o inconsciente está agindo. Para ele, vivemos regidos por esse saber que não se sabe. A partir dessa visão, é possível pensar os fenômenos humanos e identificar as manifestações também no palco social (AGUIAR, 2014).

Para Neme (2008), o Complexo de Édipo é, pois, estrutura constituinte do sujeito, efeito da entrada na linguagem e não se reduz ao drama subjetivo. Sendo assim, podemos pensar na importância do Complexo de Édipo como central na primeira infância sendo estruturante na condição do sujeito e sua subjetividade. A infância de Leonardo da Vinci retratada por Freud parece cumprir com a intencionalidade de melhor compreender a constituição subjetiva do sujeito.

\subsection{Leonardo Da Vinci e uma lembrança de sua infância}

Jean- Michel Quinodoz, no livro "Ler Freud” (2007, p.111), traz Freud no espelho de Leonardo, onde ficou fascinado desde o início pelo enigma que a vida e a obra de Leonardo da Vinci, gênio universal do Renascimento, representavam para a psicanálise. O estudo que dedicou a ele em 1910 permitiu-lhe introduzir vários conceitos psicanalíticos fundamentais, 
como de sublimação (atividade artística e investigação intelectual) e narcisismo (amor pela imagem de si mesmo).

O autor remete que Freud tomou como ponto de partida do estudo dados surpreendentes sobre Leonardo relatados por biógrafos: como se explica, por exemplo, a coincidência entre o desenvolvimento desmesurado da paixão de inventor e a renúncia progressiva da atividade de pintor, até abandoná-la? Para Freud, o impulso que leva ao conhecimento tem a fonte na curiosidade sexual infantil, isto é, no desejo que todos sentem de saber de onde vêm os bebês e que papel desempenham o pai e mãe. Porém, quando a sexualidade infantil sofre repressão excessiva, como no caso de Leonardo, a libido se transforma em curiosidade intelectual sem conteúdo sexual, mediante processo de sublimação.

Em seguida Freud, analisa a única lembrança de infância relatada por Leonardo, a de um abutre que lhe teria aberto a boca, acariciando-a com a cauda, quando ele estava no berço. Essa lembrança permite a Freud revelar uma fantasia inconsciente de felação, que dava conta da formação precoce do tipo de personalidade de Leonardo e dos modos particulares de relação. Finalmente, considerando o amor que o artista dedicava aos jovens dos quais se cercava, Freud descreveu um tipo particular de escolha de objeto, identificando-se como mãe amorosa, amando a si próprio através deles. Freud qualifica esse amor por si mesmo de narcísico

Freud relata a essência da natureza de Leonardo no trabalho "Leonardo da Vinci e uma lembrança de sua infância" (Freud,1910/1980) como conclusivo quando as recordações da infância se referirem, provavelmente, a uma fantasia, um Leonardo da Vinci (1452-1519) admirado até mesmo pelos contemporâneos, como um dos maiores homens da Renascença italiana, com influência decisiva sobre a pintura.

Sobre a infância de Leonardo, o único fragmento de informação preciso aparece num documento oficial de 1457. Trata-se de um registro de terras, em Florença, para taxação de 
impostos e que, entre os componentes da família Vinci, menciona Leonardo, de cinco anos de idade, filho ilegítimo de Ser Piero. Do casamento de Ser Piero com uma tal Donna Albiera, não houve filhos, o que tornou possível educar o pequeno Leonardo na casa do pai. Permaneceu ali até entrar para o estúdio de Andrea Del Verrocchio, como aprendiz, não sabemos com que idade.

Freud narra: “Ao que eu saiba, existe apenas um trecho nos apontamentos científicos de Leonardo em que ele insere um fragmento de informação sobre sua infância. Numa passagem acerca do voo dos abutres, ele se interrompe subitamente para descrever uma recordação da tenra infầncia, que lhe veio à memória".

"Parece que já era meu destino preocupar-me tão profundamente com abutres; pois guardo como uma das minhas primeiras recordações que, estando em meu berço, um abutre desceu sobre mim, abriu-me a boca com a cauda e com ela fustigou-me repetidas vezes os lábios". Freud, em erro de tradução, denomina a ave de "abutre" o que na verdade seria uma ave de rapina (um milhafre).

O que encontramos aí é, portanto, uma recordação de infância sem dúvida bem estranha. Não só estranha pelo que conta como pela idade a que se refere. Que uma pessoa possa lembrarse de alguma coisa da época da amamentação talvez não seja impossível, porém essa recordação não poderá, certamente, ser considerada real, porém uma fantasia que ele criou transportandoa para a infância.

Nos escritos freudianos, a fantasia se constitui aporte teórico importante no entendimento da constituição do psiquismo, sendo antes atribuído apenas à realidade material. Nesse momento de valoração da realidade psíquica, Freud (1950[1892-1899]/1980) realiza mudança na compreensão teórica do modo como os primeiros anos de vida participam do processo de constituição psíquica. A fantasia assume lugar de destaque na compreensão e na reconstrução do infantil, sendo um estatuto que vai além do que foi visto, ouvido ou vivido na infância. $\mathrm{O}$ 
infantil também se refere às sensações que ficaram grafadas no psiquismo nos primórdios da constituição psíquica. Os sons, os cheiros, as sensações táteis compõem as marcas mnêmicas primordiais e estendem-se para além delas (ZAVARONI, VIANA e CELES, 2007).

É relevante ponderar que para Freud é desse modo que muitas vezes se originam as lembranças da infância. Muito diferentes das lembranças conscientes da idade adulta, elas não se fixam no momento da experiência para mais tarde serem repetidas. Somente surgem muito mais tarde, quando a infância já acabou. Nesse processo, sofrem alterações e falsificações de acordo com os interesses de tendências ulteriores, de maneira que, de modo geral, não poderão ser claramente diferenciadas de fantasias.

O que alguém crê lembrar da infância não pode ser considerado com indiferença. Como regra, os restos de recordações, que ele próprio não compreende, encobrem valiosos testemunhos dos traços mais importantes do desenvolvimento mental. O nosso objetivo ao analisar uma fantasia da infância é o de separar o elemento mnêmico real que ela contém dos motivos posteriores que o modificam e distorcem.

Quando o adulto relembra sua infância, ela parece-lhe uma época feliz, na qual se gozava o momento e se encarava o futuro sem nenhum desejo. É por essa razão que inveja as crianças. No entanto, se nos pudessem contar a sua história nessa época, as próprias crianças provavelmente o fariam de modo diferente. Parece que a infância não é bem esse idílio bemaventurado que retrospectivamente distorcemos; ao contrário, as crianças, durante toda a infância, sentem-se fustigadas pelo desejo de crescer e de fazer o que fazem os grandes.

$\mathrm{Na}$ verdade, o grande Leonardo permaneceu como criança durante toda a vida, sob diversos aspectos. Diz-se que todos os grandes homens conservam algo de infantil. O desenvolvimento que o levou a tornar-se um artista ao atingir a puberdade cedeu lugar ao processo que o tornou pesquisador e que tem as determinantes na primeira infância. 
A distribuição dos fatores determinantes de nossa vida entre as "necessidades" de nossa constituição e o "acaso" de nossa infância pode ser ainda incerta nos detalhes, mas não será mais possível duvidar precisamente da importância dos primeiros anos da infância. Nós todos ainda sentimos muito pouco respeito pela natureza, que, nas palavras obscuras de Leonardo, que lembram Hamlet, "está cheia de inúmeras razões que nunca penetram a experiência".

Carvalho (2003) retoma as concepções de Freud, quando aponta que, ao discutir sobre a possibilidade de a lembrança de Leonardo ter efetivamente acontecido ou ser uma fantasia, Freud diz que dificilmente podemos, com clareza, separar a lembrança da fantasia, visto que as lembranças são alteradas e falsificadas em virtude de interesses posteriores. O que isso quer dizer é que nossas lembranças serão sempre tingidas por nossos desejos e interesses atuais.

Neste trabalho, subscrevemos a concepção de que a subjetividade se constitui o percurso da história pessoal e formação, não é a priori. A importância da história de vida, da memória, em nossas palavras são outras, a psicanálise trabalha com o discurso, é a memória do dizer. Nós nos constituímos nesse dizer, o que nos afeta ou afetou e a memória dá sentido até o Outro e ainda mais que estão implicados e/ou (des)velados na escrita e em ação. Com clareza, percebemos o quanto na vida fazemos escolhas muitas vezes submetidos ao que o Outro fez conosco, ou seja, nos constituímos na relação com o Outro. 


\section{CAPÍTULO 2 - A QUESTÃo DA ESCRITA NA CONSTITUIÇÃO DO SUJEITO}

\subsection{Memória Educativa}

Pensar o lugar da memória educativa é necessário a partir do reconhecimento da escrita como cerne do sujeito, constitutiva de prenúncios que nos enunciam e remetem ao que somos.

Almeida e Bareicha (2016) pontuam que, desde a ancestralidade, os humanos produzem registros, "marcas" de memória de vida e acontecimentos. Reverenciada na histórica Grécia os gregos reconhecem Mnemosyne (deusa da memória), perpetuada em diferentes períodos, alcança a contemporaneidade e se inscreve como fundante na constituição do sujeito como enigma a ser decifrado.

No dicionário de mitologia grega de Ruth Guimarães, Mnemosyne, a personificação da memória, filha de Urano e Gaia, uniu-se a Zeus durante nove noites seguidas. Deu-lhe, no período de um ano, nove filhas: as musas, representadas sob a forma de jovens mulheres vestidas com roupas longas e flutuantes e um manto, que presidem o pensamento em todas as formas.

Lethe, a personificação do esquecimento, é considerada por poetas como irmã da Morte e do Sono. Era filha de Éris, a Discórdia, e presidia a fonte do esquecimento o rio Lethe, situado nos Infernos, aonde iam os mortos beber para esquecer as coisas do mundo. Na Beócia, perto do oráculo Trofônio, havia duas fontes em que os fiéis bebiam: a fonte da Memória, Mnemosyne, e a fonte do Esquecimento, Lethe (GUIMARÃES, 1995).

Segundo o dicionário Aurélio, a palavra escrita, do italiano scritta, diz da representação de palavras ou ideias por meio de sinais, do "ato ou efeito de escrever ou redigir, escritura. Maneira, arte, técnica ou método particular de se exprimir literalmente: escritura, estilo. Arte de escrever à mão ou maneira própria de escrever". 
De outro modo, nos escritos Freud assinala que é na forma de uma escrita enigmática que o inconsciente se apresenta para interpretação. Guimarães (2007) reporta que a escrita para a psicanálise constitui um nó central de pesquisa, pois se refere à inscrição e constituição do sujeito psíquico.

Lajonquière (2010) diz que a escrita é posterior à fala, mas não por isso é derivação reduplicada daquela que aconteceu primeiro no tempo. Se, por um lado, ele afirma que não se escreve como se fala, fato reconhecido hoje até pela quase totalidade dos estudos psicolinguísticos e pedagógicos, por outro, não lembramos de quando começamos a falar uma língua chamada, curiosamente, materna. Porém guardamos certas lembranças de nossa labuta mais ou menos escolar com as letras e a escrita. Em suma, há um plus na escrita com respeito à fala (p.233).

A escrita para o autor abre a possibilidade de outra forma de habitar o mundo, isto é, o campo da palavra e da linguagem. Mas ainda poderia ser dito: instala a possibilidade de habitar mundos diversos, pois a escrita implica outra relação do sujeito consigo mesmo e com os outros. Há escritas e escritas, não apenas em se considerando a dimensão micro da vida de um sujeito com nome e sobrenome, mas também a história grande, aquela chamada humanidade. Enfim, a escrita finca as raízes na estruturação mesma da vida psíquica (p.234).

Sousa (1999) aponta que a escrita não instaura completude narcísica e, consequentemente, imaginária. Ao contrário, sustenta-se, mesmo, das lacunas e dos cortes que o escritor escava no papel, no intervalo aberto entre o familiar da língua e o desconhecido do sujeito criado pelo texto.

Freud, na carta 52, endereçada a Fliess, relata sua percepção da memória:

Como você sabe, estou trabalhando com a hipótese de que nosso mecanismo psíquico tenha-se formado por um processo de estratificação: o material presente em forma de traços da memória estaria sujeito, de tempos em tempos, a um rearranjo segundo novas circunstâncias- a uma retranscrição (FREUD, 1974). 
A palavra memória vem do latim, memoria, que quer dizer faculdade de reter ideias, impressões e conhecimentos adquiridos. Lembrança, reminiscência, recordação. Dispositivo em que informações podem ser registradas, conservadas e, posteriormente, recuperadas (FERREIRA, 2010).

O desenvolvimento do conceito de memória remetido por Almeida (2011) ocorreu convergentemente ao desenvolvimento da própria psicanálise, assim como da humanidade, destacando que 24 séculos antes da criação freudiana, Aristóteles já reconhecia o lugar essencial que a memória ocupa.

Carvalho (2003) ressalta que a memória não foi tratada conceitualmente por Sigmund Freud de forma sistemática, embora o tema possua posição de enorme importância em sua obra, já que o psiquismo é concebido como um "aparelho de memória". O papel da memória foi abordado em diversos níveis ao longo de sua vasta elaboração teórica como referência central.

Lajonquière (1999) afirma a necessidade de conhecer o passado para que não se morra subjetivamente. É fundamental que se tenha uma história para poder sustentar-se, construindo uma verdade histórica de maneira que seja possível a recriação da relação com o vivido. Diante disso, percebe-se a memória como constituinte da subjetividade do ser humano, quando, a partir da reflexão, se torna possível a ressignificação do sujeito como participante ativo e criador da própria história.

Em muitos momentos percebemos o quanto nossos traços de memória comparecem, influenciando a maneira de agir e ser. Somos feitos de memória, algumas esquecidas; outras, presentes; algumas fantasiosas do desejo ou não.

Os traços inacessíveis à consciência seriam a constituição da memória inconsciente, em que Freud se utiliza da expressão traços mnêmicos. Os traços mnêmicos fazem parte de uma concepção de memória que é “permanente e verdadeiramente inerradicável (...) designando os 
resíduos das experiências da primeira infância, para sempre inconscientes, mas dotados de valor de determinação" (RUDGE, 1999, p. 14).

Freud afirma:

\begin{abstract}
Uma das principais características do tecido nervoso é a memória; isto é, em termos muito gerais, a capacidade de ser permanentemente modificado por ocorrências únicas- característica que contrasta tão flagrantemente com a conduta de uma matéria, que permite a passagem de um movimento ondulatório para logo voltar a seu estado primitivo. Toda teoria psicológica digna de consideração terá que fornecer uma explicação para a memória (FREUD, [1895]1990).
\end{abstract}

Na metáfora do Bloco Mágico, Carvalho (2003) aponta que escrita (ou desenho) é feita com um estilete sobre a folha de cobertura e querendo-se destruir o que foi escrito deve-se apenas levantar a folha de cobertura dupla com um puxão leve pela parte inferior livre. Dessa forma, a superfície estará apta a receber novas impressões, mas sob a prancha de cera pode-se observar que ficam retidos traços permanentes do que foi escrito. Freud compara o Bloco Mágico com o Aparelho Perceptual da mente humana em virtude de ele estar sempre pronto a receber os traços mnêmicos, solucionando, assim, o problema de combinar as duas funções. A parte da cobertura de celuloide é comparada ao Sistema Pcpt-Cs (Perceptivo-Consciência), e a prancha que fica por trás do inconsciente como "órgão" de memória. Ou seja, o sistema percepção-consciência é comparado à folha que recebe a escrita que desaparece quando ela é levantada, e a memória é comparada à prancha de cera que preserva traços que só podem ser observados contra a luz.

Segundo Fernandes (2001), em “A interpretação dos sonhos”, a memória é fundante do aparelho psíquico: primeiro há a memória, depois, em decorrência dela, surge o aparelho psíquico. A memória não é entendida como propriedade, que surge depois do aparelho psíquico constituído. Ela é pré-condição para que ele se forme. "Para Freud, não há psíquico sem memória" (GARCIA-ROZA, 2002).

Na etiologia da histeria, Freud, tal como um arqueólogo, arqueólogo do inconsciente, utiliza a metáfora para compreensão do "Ur", origem da histeria. 


\begin{abstract}
"Imaginemos que um explorador chega a uma região pouco conhecida onde seu interesse é despertado por uma extensa área de ruínas, com restos de paredes, fragmentos de colunas e lápides com inscrições meio apagadas e ilegíveis. Pode contentar-se em inspecionar o que está visível, em interrogar os habitantes que moram nas imediações - talvez uma população semibárbara - sobre o que a tradição lhes diz a respeito da história e do significado desses resíduos arqueológicos, e em anotar o que eles lhe comunicarem - e então seguir viagem. Mas pode agir de modo diferente. Pode ter levado consigo picaretas, pás e enxadas, e colocar os habitantes para trabalhar com esses instrumentos. Junto com eles, pode partir para as ruínas, remover o lixo e, começando dos resíduos visíveis, descobrir o que está enterrado. Se seu trabalho for coroado de êxito, as descobertas se explicarão por si mesmas: as paredes tombadas são parte das muralhas de um palácio ou de um depósito de tesouro; os fragmentos de colunas podem reconstituir um templo; as numerosas inscrições, que, por um lance de sorte, talvez sejam bilíngües, revelam um alfabeto e uma linguagem que, uma vez decifrados e traduzidos, fornecem informações nem mesmo sonhadas sobre os eventos do mais remoto passado em cuja homenagem os monumentos foram erigidos. Saxa loquuntur! (as pedras falam)" (FREUD, 1996).
\end{abstract}

Ainda mais as elaborações de Freud em "Lembranças encobridoras" (1899/1980) no que diz respeito à memória e lembranças da infância ressaltam a inscrição do infantil no psiquismo.

Ninguém contesta o fato de que as experiências dos primeiros anos de nossa infância deixam traços inerradicáveis nas profundezas de nossa mente. Entretanto, ao procurarmos averiguar em nossa memória quais as impressões que se destinaram a influenciar-nos até o fim da vida, o resultado é, ou absolutamente nada, ou um número relativamente pequeno de recordações isoladas, que são frequentemente de importância duvidosa ou enigmática. É somente a partir do sexto ou sétimo ano- em muitos casos, só depois dos dez anos- que nossa vida pode ser reproduzida na memória como uma cadeia contatenada de eventos. Daí em diante, porém, há também uma relação direta entre a importância psíquica da experiência e sua retenção na memória (FREUD, 1980).

Como conceito de "lembrança encobridora", Freud remete como aquela que deve seu valor enquanto lembrança não a seu próprio conteúdo, mas às relações existentes entre esse conteúdo e algum outro que tenha sido suprimido. Nossas primeiras lembranças infantis serão sempre um tema de especial interesse pelo fato de as impressões de maior importância para todo o futuro geralmente não deixarem quaisquer imagens mnêmicas atrás de si, levando-nos a refletir sobre a origem das lembranças conscientes em geral.

Para Freud, as lembranças infantis mostram os primeiros anos não como eles foram, mas tais como apareceram nos períodos posteriores em que as lembranças foram despertadas. Nesses períodos de despertar, as lembranças infantis não emergiram, como as pessoas costumam dizer. Foram formadas nessa época. E inúmeros motivos, sem qualquer preocupação 
com a precisão histórica, participaram de sua formação, assim como da seleção das próprias lembranças.

Nos escritos de Lacan, é por meio dos eventos que ocorrem nos primeiros anos de vida que o sujeito vai constituir-se. Esses eventos, por sua vez, são marcados pela relação que o bebê estabelecerá com os objetos ou, mais precisamente, com a falta deles, a partir das três dimensões: o real, o imaginário e o simbólico. O real tem relação com a ordem do impossível, do não representável; o imaginário, com as imagens, com a dimensão enganosa do sujeito; e o simbólico, com a linguagem, com as leis que regem o inconsciente. Lacan acredita que a mola da relação do sujeito com o mundo é a falta do objeto, que pode ser vivenciada de três maneiras: frustação- traumas, privação e castração.

Nesse sentido, partir dos argumentos apresentados de que devemos recuperar uma história das origens relacionadas à emergência da noção de inconsciente, também ressaltamos que o ato de escrever memórias pode adquirir um sentido de inscrição. O sujeito vai se inscrevendo na ordem discursiva na medida em que procura dar conta de uma história que lhe é anterior, “constituindo-se” e recuperando as relações originárias (UR), deparando-se com o lugar do infantil (ALMEIDA E BAREICHA, 2015).

Assim pensando, compreendemos que o professor passou muito tempo em contato com seus professores como aluno, assim como com os colegas, conteúdos e rituais específicos que moldaram o processo de ensino-aprendizagem e a singularidade como docente. $\mathrm{O}$ resgate dessa memória educativa promove uma reflexão da identidade, possibilitando o autoconhecimento de maneira que também se torna possível uma ressignificação e reestruturação da própria história individual e das relações sociais que fazem parte do cotidiano do sujeito (ALMEIDA,2002).

A memória educativa fundamentada no aporte psicanalítico, portanto, é importante dispositivo de pesquisa para a compreensão da constituição da subjetividade, em especial neste trabalho de subjetividade docente. 


\subsection{A dimensão da ação na constituição do sujeito (sociopsicodrama)}

Além do aporte da escrita, a realização do sociopsicodrama permitiu novo olhar sobre a constituição do infantil na subjetividade, trazendo outra vertente como instrumento de estudo e reflexões sobre a formação do sujeito professor.

Ao buscar um corpo teórico consistente, Moreno elaborou referências para a compreensão do desenvolvimento infantil. Julgou que os primeiros padrões relacionais são desenvolvidos no relacionamento do recém-nascido com seu contexto, no processo nomeado "matriz de identidade". Assim, as primeiras estruturas interpessoais são formadas com componentes biológicos, psicológicos e sociais, influenciando as interações sociais ao longo da vida (MARRA e FLEURY, 2010).

Posterior à psicanálise surge o psicodrama que, segundo a Federação Brasileira de Psicodrama- FEBRAP-, pode ser definido como uma via de investigação da alma humana mediante a ação. É um método de pesquisa e intervenção nas relações interpessoais, nos grupos, entre grupos ou de uma pessoa consigo mesma. Mobiliza para vivenciar a realidade a partir do reconhecimento das diferenças e dos conflitos e facilita a busca de alternativas para a resolução do que é revelado, expandindo os recursos disponíveis.

De acordo com Moreno (1965):

O enfoque grupal no psicodrama refere-se aos problemas privados, por maior que seja o número de participantes. Entretanto, quando enxergamos os indivíduos como representantes coletivos de papéis da comunidade e de relações de papéis, não levamos em conta seus papéis privados e suas relações. Aí o psicodrama passa a ser um sociopsicodrama, ou, abreviando, um sociodrama.

Do lugar do sociodrama criado por Moreno, são geradas várias vertentes. De acordo com o interesse da realização, são formas de aplicar o método com influência psicanalítica. Bareicha (1999) remete à postura fenomenológica e existencial, com ênfase nas relações interpessoais, 
questões grupais, estéticas e transpessoais, enfatizando o pressuposto de que cada sujeito possui uma individualidade única.

O trabalho psicodramático, como aborda Monteiro, Merengué e Brito (2006) é feito de imersão e compreensão. A imersão pressupõe o abrir mão de qualquer certeza, de qualquer conhecimento e se lançar no desconhecimento, no não saber. É preciso, entretanto, ter um fio que o sustente, que ligue o pesquisador ao real, ao objetivo. Com isso ele pode, concretamente, elaborar- dando sentidos à experiência dramática vivida a compreensão.

O psicodrama se destaca de um enfoque puramente fenomenológico, caracterizado pelo acesso gradativo ao que aí está, ao “dasein”. Estamos para além do que aí está, ou do que se encontra em processo de desvelamento. Talvez ainda seja possível, na fase de aquecimento, empregar princípios de descrição de como as coisas existem (referência ao existencialismo), ou mesmo de como o fenômeno gradativamente nos apresenta (referência fenomenológica). Para além dessa descrição de caráter predominantemente estático ou contemplativo, desejamos provocar em nosso protagonista um salto qualitativo em direção ao novo, ao território desconhecido e não vivido (MONTEIRO, MERENGUÉ e BRITO, 2006).

O psicodrama na antiguidade, nos tempos pré-históricos, muito antes que a medicina se desenvolvesse como ciência no sentido atual, foram tratados em civilizações primitivas, com métodos quase psicodramáticos, sofrimentos psíquicos e físicos (CUKIER, 2002).

Moreno, traz conceitos de psicodrama como forma de definição e apropriamento bem como o método que penetra a verdade da alma através da ação, método de ação profunda, lidando com as relações interpessoais e as ideologias particulares, aproxima-se da própria vida.

No trabalho de Gómez, Flores e Jiménez (1996), a sistematização da investigação participativa coincide com princípios dos métodos de ação, publicados quase meio século antes. Para os autores, o enfoque constitui uma perspectiva relativista, que considera a apreensão da realidade e nosso conhecimento sob uma ótica individual e coletiva e, portanto, exige um 
envolvimento pleno dos participantes na criação de conhecimentos sociais e pessoais. Esse conhecimento se constrói pela reflexão sobre a ação de pessoas e comunidades. O resultado de todos esses métodos, como pontua Monteiro, Merengué e Brito (2006), é uma mudança na experiência vivida dos que se implicam no processo de investigação. E, com base nessa perspectiva epistemológica, os autores acrescentam a importância acentuada do conhecimento fruto da experiência vivida e da subjetividade da investigação.

Bareicha (2010) afirma que socionomia é a ciência que estuda as relações sociais sob diferentes referenciais, como a teologia, as estéticas teatrais, as filosofias humanistas e perspectivas médicas, psicológicas, sociológicas e científicas. Trata-se de poderoso e eficaz instrumento pedagógico, assim como forte mobilizador de grupos.

Segundo Figusch (2010), o projeto socionômico de Moreno explora as leis de desenvolvimento social e o desenvolvimento de relações sociais (as leis que definem o comportamento social e grupal) apoiado no tripé:

1) Sociodinâmica: o estudo das relações interpessoais, analisando a estrutura, o desenvolvimento e o funcionamento de grupos por meio da interpretação de papéis e do jogo de papéis.

2) Sociometria: medida e diagnose de relações interpessoais por meio do teste sociométrico. 
3) Sociatria: o tratamento de relações interpessoais e sistemas sociais.

Como observado no quadro 1.

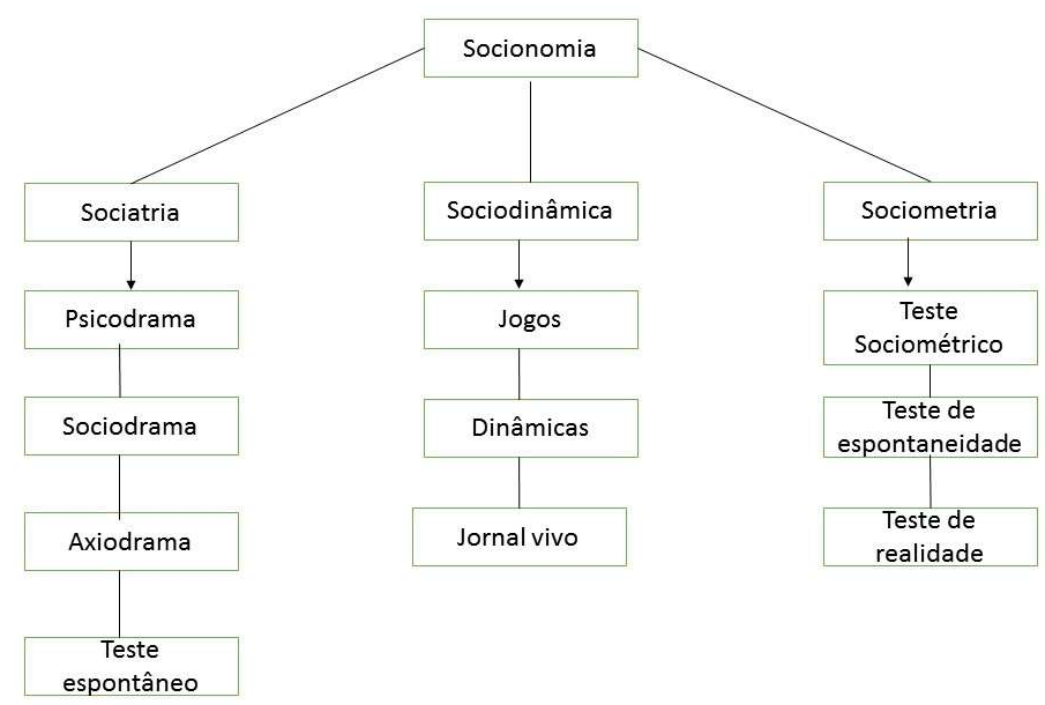

Quadro 1- Socionomia Moreniana

Fonte: Ferreira,2010.

O sociodrama, aliado ao psicodrama, é método sociátrico que funciona na intersecção dos fenômenos sociais e individuais (DAVOLI,1990). A premissa da sociatria é que não apenas a psique individual precisa ser curada, mas toda a sociedade. A palavra tem duas raízes: o latim socius (a outra pessoa) e o grego iatreia (cicatrizar ou curar). O foco de atenção está na interação entre psiques, entre membros do grupo, em suas adesões a outros membros e na natureza da interação com outros grupos (MORENO, 1992).

Em educação o sociodrama, foi introduzido em settings educacionais de todos os níveis, com o objetivo principal de desenvolver e cultivar a criatividade e espontaneidade de alunos/estudantes, possibilitando que eles se tornem agentes do próprio aprendizado. Silva (2008) mostra que o intuito, nesse caso, não é o de explorar conteúdos privados e internos dos participantes, mas expandir a consciência sobre certos assuntos e promover o desenvolvimento e o crescimento de papéis profissionais. 
Marra e Fleury (2010) enfocam que, no sociodrama, Moreno diz que todas as ações são desenvolvidas no contexto do "como se", sustentado pela atemporalidade do simbólico e do imaginário. O grupo trabalha com o objetivo de conhecer a si e aos outros na situação, dar novos movimentos aos seus papéis, transformando-os nas ações em relação aos demais participantes.

O sociopsicodrama tem sido definido como método profundo de ação que trata de relações intergrupais e de ideologias coletivas. O vocábulo sociopsicodrama tem duas raízes: socius, que significa o sócio, o outro indivíduo; e drama, que quer dizer ação. Sociopsicodrama significa, pois, ação em benefício de outro indivíduo, de outra pessoa. Cukier (2002) reforça, ainda, que o verdadeiro sujeito de um sociopsicodrama é o grupo. Não está limitado por um número especial de indivíduos. Pode consistir em tantas pessoas quantos os seres humanos que vivam em qualquer lugar ou, pelo menos, quantos pertençam à mesma cultura.

A ciência e a arte de ensinar e aprender encantam e desafiam o pensamento e a ação dos educadores. O papel da arte sempre teve algo de subversivo e de inovador: uma crítica, uma ilustração (...). Por sua vez, as ciências humanas e sociais advogam para si os fundamentos da educação, e a pedagogia nasce investida na difícil tarefa de definir seu estatuto epistemológico e, ao mesmo tempo, instrumentalizar o professor em seu imprescindível papel profissional (BAREICHA,1999).

Moreno pensa que o psicodrama pode ser considerado como a consequência lógica da psicanálise, um passo além dela, mas que inclui todos os concomitantes verbais da associação livre.

Posteriormente (1996), a publicação de Gaston Pineau e Jean Louis le Grand "Les Histoires de Vie" da série Que sais- je? compreendendo ser a história de vida tal como a memória educativa, trabalhada como pesquisa e construção de sentido a partir de fatos temporais pessoais como "o território das escritas do eu" alargando as bordas e exprimindo a vida através de biografia, autobiografia e memória. Para além das definições literárias, 
psicológicas, históricas ou disciplinares, a história de vida e/ou memória educativa pode ser abordada como prática "autopoiética" do grego autos (soi) poien (produire).

Nesse sentido, portanto, Pineau e Le Grand em seus escritos trazem as práticas da história de vida como fronteiras do existencial e profissional, público e privado, do invisível ao visível. A partir dela, a pesquisa e construção de sentido remetem a fatos temporais. Interessante pensar que buscamos nossa origem, visto a história de vida de comunidades primitivas, memória coletiva que repercute em uma realidade social.

A novidade conceitual real do livro de Pineau e Le Grand é mostrar como os mecanismos de autonomia formam uma ponte entre as dimensões cognitivas da vida, e a dimensão humana e social do conhecimento a que qualquer explicação cognitiva deve finalmente acabar. Nisso reforça a ideia de que somos história de outras histórias.

A abordagem das histórias de vida não é abordagem de um projeto, estratégia de conhecimento, programa de pesquisa, problemático. Além disso, pode ser ligada a outras formas de pensar / pesquisa (PINEAU, LE GRAND,1996).

Almeida (2004) acentua que a perspectiva de que a memória educativa tanto pode ser reconhecida como lugar de expressão da subjetividade na constituição da identidade do professor por sua vivência na instituição escolar, pensada como conjunto de práticas ou de relações sociais e marcada por significativas experiências assimiladas desde o período inicial da escolarização, quanto pode ser clareada a partir das (im)possíveis conexões com a psicanálise.

Articulando história de vida e memória se presentificando no sociopsicodrama, podemos pensar o infantil em sua constituição como forma subjetiva na reinvenção do sujeito professor, ou seja, escrita e inscrita implicadas à ação. 


\section{CAPÍTULO 3 - SUBJETIVIDADE (IM)POSSÍVEL}

A educação é o que norteia a formação do professor repercutindo sem dúvida na prática pedagógica. Ferreira (2009) enuncia que a conceituação de educação relacionada ao contexto social vem de várias concepções. Porém há, entre quase todos os autores, concordância entre dois aspectos. O primeiro, que a educação sempre expressa uma doutrina pedagógica a qual, implícita ou explicitamente, se baseia em uma filosofia de vida, concepção de homem e sociedade. O segundo, em uma realidade social concreta, o processo educacional se dá através de instituições específicas como família, igreja, escola, comunidade, que se tornam porta-vozes de determinada doutrina pedagógica.

A partir desses pressupostos e retomando a trajetória histórica da educação, constataremos que, apesar da ecleticidade de práticas pedagógicas, uma característica comum persistiu em todas as épocas: a promoção e sustentação de uma imagem ideal de homem (VOLTOLINI, 2001).

Na perspectiva da psicanálise, todavia, o sujeito é pensado como constitutivamente social, não sendo então possível pensá-lo nem à margem da sociedade, nem à margem da natureza. Em outras palavras, se para o paradigma moderno o sujeito precede a sociedade, na concepção da teoria psicanalítica os processos de subjetivação e de socialização são indissociáveis (PLASTINO, 2001).

A educação para realidade almejada por Freud, entretanto, visa ao desejo. Ela direcionava-se a tornar de difícil acontecimento que as crianças excursionem na vida adulta malvestidas e carentes de bons mapas, a ponto tal de ficarem à mercê de perecerem resignadas perante a realidade do desejo. Se o objetivo visado é o desejo, então pode acontecer uma educação (LAJONQUIÈRE, 2010).

“A impossibilidade faz com que na psicanálise, na política e na educação os resultados sempre deixem a desejar, pois eles estão aquém ou além do pretendido”, pontua Lajonquière. 
Essa posição também é sustentada por Voltolini (2011) ao reforçar que a impossibilidade afirmada por Freud diz respeito à ausência de controle de três ofícios- curar, ao lado de educar e governar. É fato essa afirmação na educação visto que não controlamos tudo, existe um real que foge à apreensão simbólica.

Sustentado ao pensamento do impossível, Rubem Alves (2004, p.37) afirma não saber como preparar um educador e isso talvez não seja possível, até porque ele, o educador, é um “fundador de mundos, mediador de esperanças, pastor de projetos”. O que se faz necessário é acordar o educador. "Basta que os chamemos do seu sono, por um ato de amor e coragem. E, talvez acordados, repetirão o milagre da instauração de novos mundos”.

O aprender implica atividade em contexto específico, relacionado ao local, ao momento, às pessoas envolvidas e às condições. A relação com o saber é além de relação com o mundo em sentido geral. É também relação com os mundos particulares, meios, espaços nos quais se vive e aprende.

Não se pode negar a dimensão subjetiva do homem, esta que se faz presente, ou se atualiza nas atitudes humanas. A subjetividade, portanto, retira o homem da perspectiva biologizante que desconsidera o inconsciente como importante componente que, no entanto, só se torna presente por meio da dimensão simbólica, da palavra, esse dom e campo privilegiado (LACAN, 1958).

Prazeres (2007) registra que o termo subjetividade no arcabouço psicanalítico expressa o assujeitamento do sujeito ao campo do simbólico - registro psíquico referente ao domínio da linguagem - ao qual todo ser tem que ser submetido para tornar-se humano.

Continua a autora, quanto à concepção da subjetividade, ser essa, como uma subjetividade clivada, o ponto fundamental na teoria freudiana: o sujeito do consciente é o sujeito do enunciado, da razão; o sujeito do inconsciente é o sujeito da enunciação, do desejo. 
Mannoni (2004) diz que os fatos vividos por uma criança, que poderiam ser testemunhados por outros, são, ao mesmo tempo, o conjunto das percepções que ela tem deles e o valor simbólico que se depreende do sentido que essas percepções assumem para o narcisismo do sujeito, amor pela imagem de si. O encontro depende das palavras, justas ou não, pronunciadas a seu propósito pelas pessoas ouvidas por ela. Essas palavras ou a sua falta conservam-se e se representarão na memória como representativas verdadeiras ou falsas do experimentado vivido.

Tudo aquilo que uma criança aprende, isto é, apreende do Outro na educação é função do desejo. O desejo freudiano não é de aprender no sentido epistemológico como se costuma pensar, ele é de apreender, mas de apreender mesmo o corpo fantasmático da mãe primordial. Ele é de natureza sexual e infantil e, portanto, radicalmente inconsciente (LAJONQUIÈRE, 2010).

Para Guimarães (2007), o enlace entre a psicanálise e a educação se faz no dia a dia, possibilitando uma forma diferenciada de posicionamento do educador diante das questões que se apresentam no processo de ensinar e aprender. A dimensão do inconsciente, o lugar de suposto saber que o educador ocupa na relação com o educando, a posição do educador com relação ao objeto de conhecimento são aspectos que fazem parte de um novo olhar, de uma nova forma de considerar os processos de aquisição do conhecimento e das relações que se dão no espaço escolar, re-significados pelo campo da psicanálise.

Na análise de Daniel Sibony (1991).

Cada professor sabe instintivamente que o que ensina não é apenas "sua" matéria, aquela pela qual é pago; mas que ao mesmo tempo, ao lado, à margem, nas bordas, ele ensina outra coisa. O quê? Tudo o que diz respeito ao ser no mundo, e ao seu para começar, tudo o que faz ver independentemente dele; uma ressonância do ser: ele mostra o que é um homem que transmite o que o apaixona, ou que recobra o que o apaixonava; um ser fraco que se entretém com os fortes, um ser forte que tem falhas, ou que aceita seus limites. Ou ainda que acusa os outros de ser seus limites; um ser que tem medo, ou que aceita o desconhecido, ou que brinca de aceitar o desconhecido sob a condição de ser disso prevenido; um ser sensível ao que ocorre ou que não deixa passar nada, nem prescindir disso; (...) um ser que fala sua presença na linguagem, um ser que mantém ou não, pouco importando seu capricho, seu método, diretivo ou não, está para além, é certa tensão do ser. 
É pelo viés de uma condição do sujeito do inconsciente que se esboça a trajetória da constituição do professor, considerando-se, nesse percurso, os processos inconscientes que vão constituindo o ser humano, apontando-se as vicissitudes pela qual o sujeito passa na formação da identidade docente. Como professora no curso de pedagogia, deparo-me com vários questionamentos e percebo o quanto a formação de professores é importante e faz a diferença em sua constituição.

Nóvoa (1992) afirma que não há ensino de qualidade, nem reforma educativa, nem inovação pedagógica, sem uma adequada formação de professores. E, no entanto, vale a pena recordá-la num momento em que o ensino e os professores se encontram sob fogo cruzado das mais diversas críticas e acusações. A crise do professor permeia até os tempos atuais e um dos problemas mais evidentes é a formação, visto que, se não acompanhamos o mundo contemporâneo, o currículo não se sustenta.

Partindo de vários pressupostos, Nóvoa (1992) diz que:

A crise de identidade dos professores não é alheia a esta evolução que foi impondo uma separação entre o eu pessoal e o eu profissional. A transposição desta atitude do plano científico para o plano institucional contribuiu para intensificar o controle sobre os professores, favorecendo o seu processo de desprofissionalização.

Blanchard-Laville (2005) traz o registro psíquico da transmissão didática como função dos formadores de professores. Bem como percebe-se que é possível recuperar zonas de trabalho vivas e restituir aos professores o desejo de transformar sua prática.

Ainda segundo Blanchard-Laville (2005), o registro psíquico não é o único a desenvolverse no espaço do ensino. Há um trabalho psíquico a fazer pelo indivíduo sobre a própria relação com o saber. Ele deveria efetuar-se nos tempos de formação, particularmente em préprofissionalização e em formação inicial e contínua, sob pena de que o trabalho psíquico não efetuado seja transportado aos espaços de ensino e se reencontre a cargo dos alunos. 
Em complementaridade, podemos perceber que, na escola, o professor pode, então, além de exercer o seu ofício, fazer descobertas de si mesmo relativas aos seus desejos, fragilidades, potencialidades. Na perspectiva da psicodinâmica do trabalho, as relações entre o sofrimento e a realidade sustentam o desenvolvimento da subjetividade; enquanto que, para o viés da psicanálise, esse processo se dá a partir das pulsões e seus destinos (DEJOURS, 2004).

Para o autor supracitado o trabalho sempre coloca à prova a subjetividade, que sai acrescentada, enaltecida, ou, ao contrário, diminuída, mortificada. Trabalhar constitui, para a subjetividade, provação que a transforma. Trabalhar não é somente produzir; é também transformar a si mesmo e, no melhor dos casos, ocasião oferecida à subjetividade para se testar, até mesmo para se realizar (DEJOURS, 2004, p.30).

Blanchard-Laville (2005, p.316) afirma que o exercício da profissão de professor se tornou difícil: as antigas defesas profissionais não bastam mais, o sofrimento identitário aumentou no decorrer dos anos. Entende-se por formação um processo que vai da busca de certezas à aceitação da dúvida, processo que impele ao desenvolvimento e à mudança. Os professores podem ser ajudados, assim como eles mesmos poderão ajudar os alunos a transformar as fraquezas em recursos.

Em contrapartida, Lajonquière (1999, p.40) salienta que o educador deve renunciar ao ideal de completude narcísica imaginária e também à ilusão de que é possível gestar, por obra dos ideais e normas educativas, pelo menos um adulto do futuro a quem nada falta.

Essa falta a ser se relaciona com o saber em que a incompletude do sujeito e sua relação com a falta serão norteadoras. No processo de ressignificação do ser professor, a memória educativa, escuta e cenas corroboram para afirmação de Freud de que o estranho é, antes de tudo, algo que se tornou estranho por ter sido antes familiar. 


\section{CAPÍTULO 4 - METODOLOGIA}

A perspectiva metodológica desta pesquisa é qualitativa, a partir da concepção de que a metodologia é o caminho do pensamento e a prática exercida na forma de abordar a realidade (Minayo, 2003). A pesquisa qualitativa é amparada pelo paradigma qualitativo, que pode também ser chamado de interpretativo, contextual ou naturalístico. Essa vertente argumenta sobre a importância de compreender o significado da experiência, das ações e dos eventos por meio da interpretação e do olhar de pesquisadores, participantes e culturas e também que é importante ter sensibilidade para a complexidade do comportamento e do significado no contexto em que realmente ocorrem (HENWOOD,1996).

Como construtor da pesquisa qualitativa Turato afirma que esse método adquiriu poder científico com os trabalhos da antropologia e posterior expansão para a sociologia e a educação. Sendo assim, a psicanálise também contribuiu para o desenvolvimento dos métodos qualitativos no estudo do humano (TURATO,2004).

Creswell (2010) afirma que a pesquisa qualitativa é um meio de explorar e de entender o significado que os indivíduos ou grupo atribuem a um problema social ou humano. O processo de pesquisa envolve questões e procedimentos emergentes: coletar dados no ambiente dos participantes; analisar os dados indutivamente, indo dos temas particulares para os gerais; e fazer interpretações do significado dos dados.

Martins e Bicudo (1989) apontam as principais características da pesquisa qualitativa:

\footnotetext{
A pesquisa qualitativa busca a compreensão particular daquilo que estuda(...) não se preocupa com generalizações, princípios e leis (...) o foco da sua atenção é centralizado no específico, no peculiar, no individual, almejando sempre a compreensão e não a explicação dos fenômenos estudados. (p.23).
}

Nesta pesquisa utilizamos o método fenomenológico que para Gil (2010) parte do cotidiano, da compreensão do modo de viver das pessoas, não de definições e conceitos, como 
ocorre em trabalhos com outras abordagens, ou seja, sob o enfoque fenomenológico resgatamse os significados atribuídos pelos sujeitos ao objeto estudado.

Segundo Almeida (2006):

\begin{abstract}
Etimologicamente, método quer dizer caminho. Caminho que a curiosidade humana percorre, indagando, correlacionando, pesquisando e refletindo, de modo ordenado, para atingir o conhecimento. O método é o caminho da ciência. Método é o conjunto de procedimentos teóricos que ordenam o pensamento, estabelecem o objetivo do trabalho a ser executado e inspiram ânimo ao investigador. O método necessita dos processamentos técnicos para atingir seus objetivos.
\end{abstract}

Neste sentido, ao buscar a vertente do humano que nos constitui tem todo sentido ancorarse na abordagem da psicanálise como aporte teórico, sobretudo o freudiano e o (sócio)psicodrama, fazendo que o trabalho tenha um significado importante a partir de todo processo de análise e interpretação dos fenômenos, dando assim significado e sentido de Ser.

A psicanálise representa importante aporte desses saberes sobre o homem, constituindose, assim, em instrumento teórico que não é possível ignorar no processo de transformação paradigmática. Com efeito, ao afirmar a existência da realidade psíquica e seu caráter genuinamente inconsciente, Freud subverteu as concepções centrais elaboradas pelo paradigma da modernidade sobre o homem, o conhecimento e o ser. Assim, não é só uma nova concepção antropológica que emerge do saber produzido pela psicanálise, mas também uma nova perspectiva ontológica e epistemológica (PLASTINO, 2001).

Plastino em seus escritos reforça que, ao constituir experiência singular de conhecimento, a psicanálise se erige não apenas como novo saber, mas como nova forma de saber, caracterizada por peculiaridades que a afastam das características postuladas pelo paradigma moderno como necessárias à produção do conhecimento. Nessa nova forma de saber, o conhecimento não é gerado por um sujeito que se debruça com neutralidade sobre seu objeto, registrando causas materiais e quantificáveis, mas é produzido no interior de um campo empírico singular, constituído por uma relação intersubjetiva caracterizada por relações de afeto, isto é, por resistências, transferências e contratransferências. Nessa singularidade da base 
empírica, e no saber que ela permite produzir, origina-se a tensa e conflitiva relação estabelecida entre a psicanálise e as categorias centrais do paradigma moderno.

Sendo assim, Safra reforça que:

\begin{abstract}
O método psicanalítico é posicionado não na busca de um objetivo determinado ou de algo a ser concluído, mas como um procedimento processual. Trata-se de uma característica do processo psicanalítico diretamente relacionada às peculiaridades da subjetividade humana: a contínua abertura para o devir. Essa perspectiva pode ser encontrada nos trabalhos de Lacan, nas formulações de Bion ou nas de Winnicott. Temos aqui um princípio fundamental da investigação em psicanálise: ela é um processo investigativo não conclusivo (SAFRA,2001).
\end{abstract}

Aguiar (2014) ressalta que, para Freud, a ciência busca correspondência com a realidade, que deixa de fora tanto o sujeito quanto seu desejo. Para ele, a ciência só baseia sua "verdade" universal em seus experimentos. Tomando por base o pressuposto de que o sujeito é desde sempre dialético, dividido pela linguagem, pensar um saber que deixa de fora o sujeito, bem como a condição conflituosa do humano, não condiz com o dever ético da psicanálise, que tem, segundo Quinet (2012), o poder de sustentar a existência do saber inconsciente por meio da convocação da subjetividade como desejo.

Nesse interlace da psicanálise como método de pesquisa, estabelecemos também conexões com outra vertente enriquecedora trazendo sociodrama. Moreno (2008) aponta que o método estaria baseado nas afinidades entre as pessoas e nos padrões resultantes de suas interações espontâneas, padrões esses utilizados como guia para a classificação, para a construção e, quando necessário, para a reconstrução dos agrupamentos.

O psicodrama foi criado à margem da psicanálise. Algumas vezes, foi seu reverso; em outras, uma versão diferente; e em certos pontos, outra coisa. Nasceu sob o signo da contestação, contrapondo aquela mesma psicanálise materialista, dura, determinista, que a compreendida por Jacob Levy Moreno, imerso na Viena do começo do século passado. Talvez, hoje, mais sensatamente, possamos considerar interessantes e potentes ambas as propostas, sem deixar de inscrevê-las na História (MONTEIRO, MERENGUÉ e BRITO, 2006). 
Fleury e Marra (2010) reforçam que, quando, na aplicação do método do sociodrama, considerou toda a plateia como atores sociais, agentes terapêuticos, ele tinha a certeza de que, ao ampliar a subjetividade do sujeito no compartilhamento de suas emoções, histórias, percepções, estaria alargando a capacidade e expansividade desses sujeitos, buscando interação que fosse mais eficaz para si próprios.

Buscando melhor coleta de dados e coerência com a pesquisa qualitativa, a teoria moreniana é exemplo de conhecimento gerado que, ao ser considerada metodologia no âmbito da epistemologia qualitativa, pode ser integrada ao debate científico na originalidade e complexidade (MONTEIRO, MERENGUÉ e BRITO, 2006).

Marra e Costa (2004) consideram o sociodrama uma ferramenta de pesquisa qualitativa, argumentando que grupos e organizações podem ser mais bem investigados no funcionamento em plena manifestação da espontaneidade e criatividade, o que, de certa forma, se aproxima de Creswell (2010) quando aponta que a pesquisa fenomenológica é estratégia qualitativa em que o pesquisador identifica a essência das experiências humanas sobre um fenômeno descrito pelos participantes em um estudo.

Considerando os elementos metodológicos, interessante esclarecer, tal como Bonfim (2015), que os conhecimentos psicanalíticos podem ser aplicados a quaisquer áreas do conhecimento, sem que estejamos aplicando seu método. Essa vertente sustentada por Celes (2000) observa que:

É na prática analítica onde ocorre a observação primeira e sua riqueza. É a prática que se dá a observar e é ela que se abre à observação, constitui-se na seta, na indicação do caminho da observação, mesmo quando esta extrapola, stricto sensu, a prática analítica, como acontece, por exemplo, nas psicanálises de obras de artes, cultura, etc., práticas estas outras que Freud mesmo deu início e que fizeram romper os limites inicialmente previsíveis da psicanálise (CELES, 2000).

O autor ressalta o quanto a psicanálise compreendida por Freud como método de tratamento das neuroses, teoria sobre os processos anímicos e processo de investigação desses mesmos processos se constitui e se torna realmente o que consideramos como pesquisa 
científica entendida como procedimento de fazer ver e a metodologia discurso do método de observação-observação que é fundamento da pesquisa científica. A primazia do "ver" se traduz como ver com um outro olho, que supervisiona que vê sobre o que se dá no trabalho, que vê a visão própria do trabalho-controle metodológico do método da pesquisa científica.

\subsection{Delineamento da pesquisa}

Baseado nesses pressupostos metodológicos e contemplando a pesquisa em questão, seguimos um organograma utilizando os dispositivos de forma articulada.

Criamos um curso em que as etapas da pesquisa foram contempladas, ofertado às professoras, em parceria com a Escola de Aperfeiçoamento dos Profissionais de Educação (EAPE). A ideia da parceria surgiu com o intuito de formação das professoras vislumbrando melhor campo para o desenvolvimento do trabalho. O curso, intitulado O lugar do infantil na memória educativa: implicação e reflexão em escrita e ação, foi ofertado no decorrer das coordenações das professoras e com o aceite da direção e professoras que assinaram o termo de consentimento livre e esclarecido para pesquisa.

Elaboramos um projeto com a descrição de todos os passos do curso, fizemos todo o percurso orientado para o aceite da parceria. Após a aprovação, entramos em contato com a escola no sentido de oportunizar os encontros.

\subsection{Local da pesquisa}

A pesquisa foi realizada em uma escola da rede pública de Ensino Fundamental I, trabalhando com alunos do $1^{\circ}$ ao $5^{\circ}$ ano, localizada em Brasília-DF. Iniciamos um processo de análise e observação, em que tivemos acesso ao Projeto Político Pedagógico (PPP) da escola, cuja proposta vem sendo cuidadosamente construída pela comunidade escolar desde 1996, considerando as necessidades de cada segmento e os principais documentos norteadores da 
Educação Básica Nacional, regidos pela Constituição da República Federativa do Brasil. Desde então, é atualizada a cada ano, com avaliações periódicas.

Pudemos perceber o comprometimento e a excelência dos projetos implantados e a preocupação com a parceria da família realizando levantamentos de expectativas com toda a comunidade escolar. A escola é muito receptiva. Várias dissertações de mestrado e teses de doutorado a tiveram como espaço de pesquisa.

O maior desafio da escola vem sendo a rotatividade dos professores e as constantes substituições decorrentes de licença médica, o que mobiliza coordenadores e professores comprometendo a rotina semanal.

A equipe profissional é composta de diretora, vice-diretora, chefe de secretaria, auxiliar de secretaria, coordenadora pedagógica, orientadora educacional, professoras, equipe especializada de apoio à aprendizagem/sala de recursos, bibliotecária, equipe de limpeza, equipe de alimentação e equipe de vigilância.

Após um longo trabalho no sentido de reduzir o número de alunos em sala para atender adequadamente às necessidades individuais, a instituição vem obtendo significativo sucesso, a estratégia de matrícula tem respeitado as reduções necessárias nas turmas, considerando a real capacidade física da escola e as necessidades dos alunos previstas em lei. São 300 estudantes, distribuídos em 14 turmas, nos turnos matutino e vespertino. Maioria das turmas é reduzida em atendimento aos direitos dos alunos com necessidades educacionais especiais, conforme prevê a legislação.

A clientela é formada por alunos na faixa etária se 5 a 13 anos, pertencentes à Unidade de Vizinhança da Residência e Trabalho (UVIRT), moradores das quadras vizinhas, das regiões administrativas e do entorno. Há educandos de todas as camadas sociais. Nem todos têm acesso, em sua comunidade, à diversidade dos bens culturais, à leitura e aos recursos tecnológicos. 
A escola tem por finalidade proporcionar, na perspectiva da qualidade social, uma educação para o pleno desenvolvimento de seus sujeitos, construindo relações de cidadania com a participação de todos.

Além dos documentos orientadores da SEDF- Secretaria de Estado de Educação do Distrito Federal, a escola considera a pertinência do relatório da UNESCO- Um tesouro a descobrir, que indica quatro pilares para a educação do novo milênio: aprender a aprender, aprender a fazer, aprender a conviver, aprender a ser com vistas a considerar o educando verdadeiro responsável pelo próprio processo educacional a partir das ações bem planejadas e estruturadas da escola, para atender às necessidades de aprendizagem, considerando as discussões de estudiosos, do mundo inteiro, sobre os processos de aprendizagem e, consequentemente, os de "ensinagem".

Algumas metas vêm ao encontro da oportunização da pesquisa em si, como:

- Capacitar semestralmente a equipe no que tange ao conhecimento da legislação brasileira, através de palestras, reuniões, dinâmicas de grupo e troca de experiências, estimulando-os a estar sempre em busca de novos conhecimentos e aprimorando as atividades laborais.

- Oportunizar a participação de servidores em cursos de formação promovidos anualmente pela rede pública de ensino ou demais órgãos educacionais.

- Promover encontros coletivos semanais com o corpo docente para planejamento e discussão das práticas educacionais.

A equipe gestora é composta de diretora e vice-diretora eleitas pelo processo de Gestão Democrática, do Conselho Escolar igualmente eleito conforme a Lei $N^{o} 4.751$, de 07 de fevereiro 2012/ Portaria $n^{\circ}$ 98, de 27 de junho de 2012, e do chefe de secretaria.

A gestão da escola recebe o apoio da Associação de Pais e Mestres- APM, entidade civil que tem como objetivo essencial integrar a comunidade, o poder público e privado, a escola e 
a família, buscando o desempenho mais eficiente do processo educativo, com foco específico no suporte à formação do educando cidadão.

A participação ativa da comunidade tem sido marca na trajetória histórica da escola. Tem contribuído para a reestruturação e avaliação da gestão, promovendo conquistas nas áreas administrativa, física, financeira e o alcance dos objetivos educacionais. Fixa o foco no desenvolvimento pleno do educando e na participação da comunidade na instituição educacional.

\subsection{Sujeitos da Pesquisa}

As professoras participantes da pesquisa foram inicialmente 19 e, por isso, o curso foi ofertado no período matutino e vespertino. $\mathrm{O}$ aceite formal foi feito com a assinatura do Termo de Consentimento Livre e Esclarecido (Apêndice A). Das 19 professoras participantes, apenas duas não fizeram a entrega do termo por questões de cunho pessoal, sendo assim, os seus dados não puderam ser considerados. Das 19 participantes, 12 são efetivas da Secretaria de Estado de Educação do Distrito Federal e 07 têm contrato temporário, uma é efetiva e tem a função de orientadora educacional. Todas são professoras do Ensino Fundamental I, regentes de sala de aula. Com exceção da coordenadora, orientadora educacional, vice-diretora e uma professora da sala de recursos, chama a atenção o predomínio feminino. Devido esse fato no decorrer do trabalho tratamos os sujeitos como professoras. 
As participantes tiveram a identidade preservada, mantendo o sigilo da pesquisa. Ao longo da análise de dados, foram identificadas como professora A, B, C, D, E, F, G, H e I .

\begin{tabular}{|c|c|c|c|c|}
\hline Idade & Sexo & Modalidade de contrato & Entregou a memória & Entregou o termo de consentimento \\
\hline 39 & F & Efetiva & Não & Sim \\
\hline 45 & F & Efetiva & Sim & Sim \\
\hline 40 & F & Efetiva & $\operatorname{Sim}$ & Sim \\
\hline 35 & $\mathrm{~F}$ & Contrato temporário & Não & Sim \\
\hline 35 & F & Contrato temporário & Não & Sim \\
\hline 24 & F & Contrato temporário & Não & Sim \\
\hline 34 & F & Contrato temporário & Sim & Sim \\
\hline 47 & $\mathrm{~F}$ & Efetiva & Sim & Sim \\
\hline 26 & F & Contrato temporário & Sim & Sim \\
\hline 53 & F & Efetiva & Sim & Sim \\
\hline 27 & $\mathrm{~F}$ & Contrato temporário & Sim & Sim \\
\hline 38 & F & Efetiva & Não & Sim \\
\hline 53 & $\mathrm{~F}$ & Efetiva & Não & Sim \\
\hline 49 & F & Efetiva & Sim & Sim \\
\hline 36 & F & Contato temporário & Não & Sim \\
\hline 46 & F & Efetiva & Não & Sim \\
\hline 45 & F & Efetiva & $\operatorname{Sim}$ & Sim \\
\hline-- & F & Efetiva & Sim & Não \\
\hline-- & F & Efetiva & Não & Não \\
\hline
\end{tabular}

Quadro 2 - Dados demográficos dos sujeitos de pesquisa

Fonte: a autora

\subsection{Instrumentos de Pesquisa}

De acordo com André e Gatti (2010), a pesquisa qualitativa na área da educação tem sido desenvolvida nas seguintes bases: em correntes fenomenológicas; na perspectiva histórica das vertentes dos estudos autobiográficos, das histórias de vida e da história oral; nos referenciais originados na sociologia e no campo dos estudos culturais; em estudos apoiados em autores pós-modernos; e nos estudos etnográficos sobre o cotidiano da escola. Destacam-se como os mais significativos atualmente, em termos de produtividade, os estudos centrados na 
perspectiva do sujeito e na linha sócio-histórica, os fundamentados na teoria das representações sociais e nas investigações sobre a constituição da identidade do sujeito, fundamentados na psicologia social, na sociologia das profissões e na psicanálise.

Atendendo a essa tendência e buscando os objetivos da pesquisa, escolhemos dispositivos norteadores como observação (diário de campo), memória educativa, sociopsicodrama e entrevistas semiestruturadas.

\subsection{Dispositivos}

Fundamentados nesses pressupostos metodológicos, seguimos um organograma para melhor desenvolvimento da pesquisa utilizando os dispositivos de forma articulada.

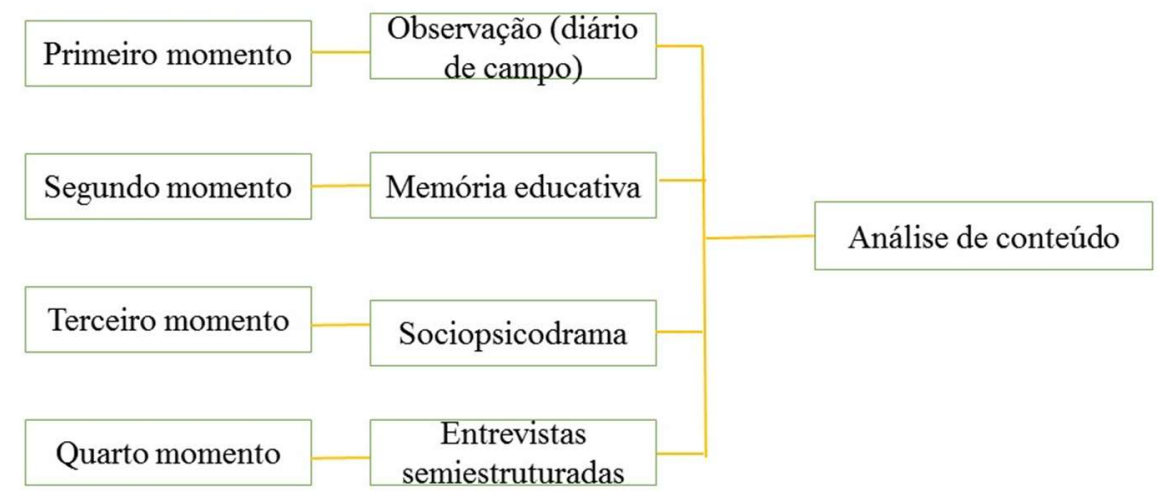

Quadro 3 - Dispositivos

Fonte: a autora 


\section{Observação (diário de campo):}

De acordo com Falkembach (1987), o diário de campo é um caderno de anotações em que devem ser registradas todas as observações de fatos concretos e fenômenos sociais. O diário de campo facilita o registro da observação e a descrição dos acontecimentos, além de estimular o exercício da escrita e o olhar atento do pesquisador.

Nesse sentido, foi construído a partir das observações realizadas (Apêndice G).

\section{Memória educativa:}

A memória educativa não é simplesmente um texto documento, mas dispositivo (enunciação mínima do sujeito inconsciente). Embora tenha materialidade, o que se pretende é compreender, interpretar os sentidos do que escreveu, isso não será tão evidente e deverá ser escrito pelos sujeitos. Para construção da memória educativa, foi utilizado o espiral como forma norteadora (Anexo A) e textos que remetem à importância da memória.

\section{Dispositivo sociopsicodramático:}

Durante três encontros do curso (por meio de oficinas vivenciais), foram realizados os sociopsicodramas. Em alguns casos, serviram de auxílio na escrita da memória educativa. Interessante pensar que vivemos vários contextos como psicodrama, sociodrama e axiodrama, de acordo com o momento do grupo. Tratando-se da sociatria, esta pesquisa contemplou as três formas citadas.

Moreno em seus escritos traz que a abordagem de grupo no psicodrama refere-se a problemas "privados" por maior que seja o número de indivíduos que possam constituir o público. Mas logo que os indivíduos são tratados como representantes coletivos de papéis, não levando em conta os papéis privados e suas relações, o psicodrama converte-se num 
"sociopsicodrama" ou, mais brevemente, num sociodrama. Abre novos caminhos à análise e ao tratamento de problemas sociais.

Já o axiodrama, síntese de psicodrama e da ciência de valores (axiologia), dramatiza as aspirações morais do psiquismo individual e coletivo (justiça, verdade, beleza, bondade, complexos, perfeição, eternidade, paz).

\section{Curso/Oficina:}

Ao longo do processo, foram desenvolvidas oficinas, realizadas durante as coordenações das professoras para a realização do sociopsicodrama e a construção da memória educativa. $\mathrm{O}$ curso O lugar do infantil na memória educativa: implicação e reflexão em escrita e ação, em parceria com a EAPE, teve como previsto sete encontros. Inicialmente foi apresentada a proposta do curso com a presença dos envolvidos e posteriormente os outros momentos como previsto.

\section{Entrevistas semiestruturadas:}

Organizada de forma semiestruturada, a entrevista foi realizada e gravada individualmente com quatro professoras participantes da pesquisa e composta por questões abertas (Apêndice E).

A entrevista semiestruturada, segundo Triviños (1992), é composta por um roteiro previamente elaborado, que atende aos objetivos da pesquisa, mas, ao mesmo tempo, proporciona flexibilidade para explorar outros tópicos que não estejam contemplados nas perguntas elaboradas.

Bauer e Gaskell (2002) assinalam que a entrevista individual é método que fornece dados importantes que possibilitam a compreensão do fenômeno estudado, de forma que diversas variáveis sociais, econômicas, políticas e individuais possam surgir durante toda a coleta de 
dados. A entrevista semiestruturada busca explorar abordagens mais subjetivas e complexas que não podem ser alcançadas por meios quantitativos tradicionais. Essa abordagem apresenta muitas possibilidades na análise e resumo dos resultados.

\subsection{Trajetória da Pesquisa}

A coleta de dados se iniciou em março e se encerrou em julho de 2016. Primeiramente entramos em contato com a escola. A primeira conversa se deu com a diretora que prontamente aceitou a pesquisa e ficou muito contente com a ideia do curso e de formação para as professoras, visto que, segundo ela, é de suma importância para elas, proporcionando mudanças no âmbito escolar. Fizemos o primeiro encontro explicando o projeto aos participantes e solicitamos a assinatura do Termo de Consentimento Livre e Esclarecido.

As professoras assinaram o termo com exceção de duas professoras regentes, conforme a Resolução número 196, de 10 de outubro de 1996, do Conselho Nacional de Saúde, que regulamenta as pesquisas realizadas com seres humanos (MOROZ; GIANFALDONI, 2006).

O curso, coordenado pelos professores Dra. Inês Maria Marques Zanforlin Pires de Almeida e Dr. Paulo Sérgio de Andrade Bareicha, teve a orientação e participação também de uma aluna da graduação de pedagogia, com o projeto do PIBIC- Programa Institucional de Bolsas de Iniciação Científica intitulado A importância da dimensão do amor, da presença e da palavra na transmissão de ensinamentos, desenvolvido por uma graduanda em pedagogia, ambas sob a mesma orientação que responde às demandas institucionais/ acadêmicas sobre articulação pós graduação e graduação.

No início do curso, após a apresentação da proposta utilizando um fôlder com a disposição das atividades (Apêndice D), abrimos espaço para perguntas e esclarecimentos, vivenciando a escuta sensível. Nesse momento, utilizamos conceitos provenientes da teoria psicanalítica, da relação com a educação e a constituição da subjetividade. 
O principal objetivo do curso de extensão: compreender a dimensão do infantil na constituição da subjetividade de professores à luz da teoria psicanalítica. Como justificativa, destinou-se a coleta de dados necessários para a pesquisa. Os conteúdos abordados foram: articulações, memória e sociopsicodrama, constituição da subjetividade e o infantil freudiano, memória educativa, o lugar da memória na psicanálise. Em anexo se encontra a proposta feita à EAPE (Anexo B).

O curso proporcionou, além dos conteúdos trabalhados, a discussão sobre sexualidade infantil (Complexo de Édipo, sexuação, desejo, fantasia) sendo uma demanda apresentada pelo grupo de professoras na relação com os alunos, tema que muitas afirmaram não se sentirem seguras para trabalhar com eles. Para tanto, cada professora recebeu um DVD com o filme "Minha vida em cor-de-rosa" e o artigo do professor Dr. Marcelo Ricardo Pereira "MeninoMenina” (2013), que remete ao filme.

As atividades, realizadas quinzenalmente nos dois turnos, matutino e vespertino, totalizaram sete encontros, com a apresentação da pesquisa, palestra inicial: conhecendo a Psicanálise- criador e criação (Freud), Memória Educativa, realização do Sociopsicodrama(três oficinas), entrevista semiestruturada e encerramento.

As professoras receberam coletânea com textos que remetiam aos conteúdos ministrados, o roteiro para elaboração da memória educativa, um espiral gráfico orientando a escrita da memória, DVD com o filme citado e utilização de uma sala virtual google groups onde recebiam informações e material.

Com o término do curso, iniciamos a análise de dados com a leitura da memória, transcrição das entrevistas, análise dos sociopsicodramas revelando um matérial riquíssimo do trabalho. 


\section{CAPÍTULO 5 - ANÁLISE DOS DADOS}

A análise foi realizada baseada na análise de conteúdo proposta por Bardin (2011), compreendendo que o mesmo é um instrumento polimorfo e polifuncional que impõe ao pesquisador o prolongamento do período de latência entre a intuição aleatória, a partir de uma leitura inicial dos dados até a reação interpretativa e compreensiva na essência. $\mathrm{Na}$ análise qualitativa, a presença ou a ausência de uma característica de conteúdo ou de um conjunto de características num determinado fragmento de mensagem é tomada em consideração (p.27).

De acordo com a Análise de Conteúdo de Bardin, podem-se utilizar os três polos cronológicos propostos: a pré-análise; a exploração do material; e o tratamento dos resultados, a interferência e a interpretação.

A pré-análise é a fase de organização propriamente dita. Corresponde a um período de intuições, mas tem por objetivo tornar operacionais e sistematizar as ideias iniciais, de maneira a conduzir a um esquema preciso do desenvolvimento das operações sucessivas, num plano de análise (Bardin,2011, p.125). Foi o primeiro momento que proporcionou a leitura de documentos como o Plano Político Pedagógico da Escola (PPP), as observações e participação nas coordenações registrando momentos significativos e passíveis de interpretação e análise, uma forma de organizar-se por meio da leitura flutuante.

Na exploração do material, torna-se necessário saber a razão por que se analisa e explicitála de modo que se possa saber como analisar. Retomando os objetivos propostos, criamos categorias em consonância com a fundamentação teórica.

No tratamento dos resultados, a interferência e a interpretação, surge a ideia da categorização, em que a análise de conteúdo se assenta implicitamente na crença de que a categorização, passagem de dados brutos a dados organizados não introduz desvios no material, mas que dá a conhecer índices invisíveis, ao nível dos dados brutos (BARDIN, 2011, p.149). 
Do ponto de vista freudiano, a interpretação é permeada de um sentido próprio e singular da psicanálise como norteadora no decorrer das análises, e nos escritos de Freud sobre os sonhos.

\begin{abstract}
A Psicanálise nos ensina o seguinte: todo sonho possui um sentido; sua singularidade procede das deformações que sofreu a expressão do mesmo; seu absurdo é intencionado e expressa a burla, o insulto e a contradição; sua incoerência é diferente para interpretação (FREUD,1973, p.654).
\end{abstract}

Ao retomarmos os objetivos desta pesquisa e vislumbrando o infantil na constituição da subjetividade, percebemos o quanto os dispositivos foram importantes na obtenção de dados. O referencial teórico sustentou todo o processo.

A constituição do infantil é marcante e visível na escrita das memórias e em todo o processo, marcas encharcadas de significados que repercutem no dia a dia da sala de aula. Ao escrever a memória as professoras se viram como alunas e perceberam o olhar docente como importante no processo de constituição, remetendo o infantil como o centro da subjetividade. Interessante perceber as implicações da atuação das professoras que levam consigo momentos se presentificando na relação com o aluno na sala de aula. Para algumas ficou clara a importância da relação professor-aluno e o quanto essa relação é regada de significados.

"Todas as vivências que tive, das mais dolorosas às mais suaves, me ajudaram a construir o que sou”. (Professora G)

A ideia do curso utilizando as professoras como sujeitos de pesquisa foi ao encontro da proposta de repercutir o resultado ao questionamento de como o professor compreende o significado da dimensão do infantil e as possíveis repercussões. Na escrita da memória, as falas durante o sociopsicodrama e na entrevista foram expressivas do quanto percebiam as marcas deixadas em sua formação e o quanto reproduziam em sala ou se privavam de transmitir conhecimentos que foram negativos em suas constituições. $\mathrm{O}$ infantil presente se manifesta de certa forma trazendo à tona a subjetividade de cada uma. Algumas sinalizaram que ficaram atentas a sua prática na percepção de possíveis transmissões. Compreender questões da ordem 
da psicanálise faz que façamos as pazes com a criança que nos habita, saber que somos seres inacabados e trazemos traços do infantil que repercutem na prática docente.

Beillerot (2000) corrobora ao trazer o conceito de análise como ideia de uma forma ou um método de pensar que impõe uma operação de fragmentação, divisão. Assim, analisar algo indica dissecação dos conteúdos a serem examinados. Esse é um elemento fundamental que implica também no reconhecimento de que o todo se constitui de partes, que, quando identificadas, permitem a compreensão da totalidade. Evidentemente, na realidade psíquica do sujeito, o todo, o contexto e o social são inegavelmente fundamentais para a análise das práticas profissionais (AGUIAR, 2014).

Destaca-se que a análise de conteúdo utilizada também é um conjunto de técnicas de análise das comunicações. Não se trata de instrumento, mas de leque de apetrechos; ou, com maior rigor, será um único instrumento, mas marcado por grande variedade de formas e adaptável a um campo de aplicação muito vasto: as comunicações.

Para Mezan (1994), a psicanálise não está apenas atrelada ao espaço clínico. Ela pode ser encontrada em todo e qualquer tipo de produção humana, visto que estamos falando de uma perspectiva. Sendo assim, a análise dos conteúdos produzidos no grupo é passível de interpretação psicanalítica, pois remete às experiências e vivências humanas.

O método da psicanálise é interpretativo. Decifrar, traduzir, interpretar é algo que sempre foi feito, mas Freud inventou um método de interpretação próprio, assentado na livre associação do analisando, só possível pela via da transferência e mediante a escuta livremente flutuante do analista, como consequência da exigência técnica da neutralidade (AGUIAR,2006).

A atenção flutuante, recurso largamente conhecido no campo da psicanálise que foi concebido por Freud para guiar suas investigações durante a escuta de seus pacientes, permite ao psicanalista não concentrar sua atenção a priori em nenhum ponto do discurso do analisando. Assim, todos os elementos da cadeia discursiva adquirem o mesmo valor e só posteriormente, 
no decorrer da fala, um ponto ou outro toma destaque por insistência em fazer-se representar. Este recurso tem a finalidade de diminuir a possibilidade de o psicanalista ficar preso a preconcepções, sejam teóricas ou pessoais, a respeito do analisando, permitindo uma abertura para que o discurso tenha sua eficácia (GUIMARÃES,2007).

O recurso pode ser aplicado também a outros lugares em que a psicanálise se faça presente, bem como a uma instituição escolar em especial. Vale-se da livre associação, quando nenhum dado é privilegiado ou desconsiderado, permitindo a presença do inconsciente.

Na realidade, a técnica é muito simples. Recusa todo o meio auxiliar, inclusive a mera anotação. Consiste em não tentar reter especialmente nada e acolher tudo com igual atenção flutuante. Desse modo, nos desembaraçamos de um esforço de atenção impossível de sustentar durante muitas horas por dia e evitamos um perigo inseparável da retenção voluntária, pois, quando forçamos voluntariamente a atenção com uma certa intensidade, começamos também, sem querer, a selecionar o material que nos foi oferecido: nos fixamos em um elemento determinado e eliminamos, em troca, outro, seguindo nessa seleção nossas esperanças ou nossas tendências. E isto é precisamente o que mais devemos evitar. Se, ao realizar tal seleção, nos deixamos guiar por nossas esperanças, corremos o risco de não descobrirmos jamais senão aquilo que já sabemos, e, se nos guiamos por nossas tendências, seguramente deturpamos a possível percepção. Não devemos esquecer que, na maioria das análises de nossos pacientes, ouvimos coisas cuja significação somente a posteriori descobrimos (FREUD, 1981 [1912], p.1654).

Safra (2006) afirma que a psicanálise contribui para que haja um situar das ciências do homem, o que significa questionar o próprio pensamento- conhecimento científico. Por quê? Porque o discurso científico ou a teoria de um cientista está "prenhe de significados inconscientes". Ela desmancha essa perspectiva de anseio de objetividade, de uma afirmação de uma realidade objetiva e abstrata. A teoria está atravessada pelos significantes do 
inconsciente, que atravessa as diferentes concepções psicanalíticas existentes. O homem não é uma totalidade, um ser fechado; é um ser deslizante. No domínio do desejo ou do devir, o homem é um ser em construção.

\begin{abstract}
O método psicanalítico é posicionado não na busca de um objetivo determinado ou de algo a ser concluído, mas como um procedimento processual. Trata-se de uma característica do processo psicanalítico diretamente relacionada às peculiaridades da subjetividade humana: a contínua abertura para o devir. Essa perspectiva pode ser encontrada nos trabalhos de Lacan, nas formulações de Bion ou nas de Winnicott. Temos aqui um princípio fundamental da investigação em psicanálise: ela é um processo investigativo não conclusivo (SAFRA, 2001).
\end{abstract}

Para a elaboração dos resultados, o material das observações, entrevistas, sociopsicodrama foram transcritos e lidos algumas vezes a fim de constatar pontos pertinentes e importantes de análise. A análise de dados se deu a partir do contexto de cada observação, entrevista realizada com base no viés da teoria psicanalítica. A transcrição das entrevistas e do material gravado como o sociopsicodrama foi minuciosamente detalhada, tendo sido registradas literalmente as falas das professoras, sem realização de sínteses, correções ou suposições.

Importante lembrar o argumento de Lacan (1998) de que a psicanálise só se aplica, em sentido próprio, como tratamento e, portanto, a um sujeito que fala e ouve. Fora desse caso, só pode tratar-se do método psicanalítico, aquele que procede à decifração dos significantes, sem considerar nenhuma forma de existência pressuposta do significado. (...) uma investigação, na medida em que observa esse princípio, pela simples honestidade de adequação ao modo como um material literário deve ser lido, encontra na ordenação de sua própria narrativa a própria estrutura do sujeito que a psicanálise designa.

Nesta perspectiva, entendemos, como Almeida (2009), que é possível pensar a memória educativa como a palavra contida na enunciação mínima do professor, com poder também de construir uma verdade histórica, de produzir uma nova relação com o vivido e possibilitar um presente que não esteja retido no passado, construindo e (re)construindo a sua identidade de educador, rompendo com práticas repetitivas e mecânicas. Enfim, a aposta teórico-prática da 
elaboração da memória educativa visa alcançar o objetivo de desencadear um processo no qual o professor atuante e/ou em formação possa fazer as pazes com a criança que está dentro dele.

Vivenciando os momentos do curso, as professoras redigiram sua memória educativa. De 19 inscritas, 10 entregaram a memória. Cada uma com o olhar e estilo próprio.

A partir das análises tanto das memórias, quanto de entrevistas e cenas vivenciadas no sociopsicodrama, foram elaboradas três categorias que emergiram contribuindo para a pesquisa:

- Laços e suas vicissitudes

- Processos identificatórios e transferência

- Mal-estar do professor: da inscrição à elaboração

\subsection{Laços e suas vicissitudes}

O caminho pelo jardim de florzinhas rosas pequenininhas que atraíam abelhas, o acolhimento diário na porta da escola pelo porteiro X e em seguida pelo casal diretor da escola, o suquinho de frutas vendido nas garrafinhas de vidro higienizadas $e$ reutilizadas de leite de coco, o uniforme de tecido, short-saia azul-marinho e camisa azul clarinho com imagem de uma santa no escudo do bolso. Enfim...saudades desse tempo (Professora A-memória educativa).

Me achava lindinha vestida de saia vermelha curtinha, blusa branca posta por dentro da saia, meia branca e tênis conguinha; levava uma merendeira vermelha com alças brancas (nela havia uma garrafinha azul com tampa branca). Minha bisa me levava, creio que era a fase do Jardim de Infância. Lembro-me bem do período da $1^{a}$ à $4^{a}$ série (professora B-memória educativa).

Perpassando pelo referencial teórico percebemos a importância do infantil, em que Freud atribui às experiências infantis valor determinante e fundante no psiquismo e na constituição da subjetividade.

Em “Lembranças Encobridoras”, Freud (1901/1904) critica a ausência ou pouca relevância atribuída às lembranças dos primeiros anos de vida, assegurando que as marcas do infantil estão na base da formação do sujeito. Nesse contexto, buscamos na categoria a importância que os laços inscritos marcam e são essenciais na constituição subjetiva do professor. 
Do ponto de vista freudiano, as lembranças da primeira infância podem ser explicadas a partir das próprias recordações, com as quais conta a própria história. As recordações não podem ser desprezadas, uma vez que o que a memória preserva é o elemento mais significativo em todo o período da vida. Estas recordações cheias de significados podem ser encontradas em excertos de memória.

Lembro da minha formatura do jardim de infância, minha irmã que me acompanhou, segurando o diploma na escadaria da futura escola em que iria estudar, pois ficavam juntas. Algo que me chama a atenção é a ausência de memórias sobre o cotidiano de aprendizagem. Sinto que vivia fora da casinha! Vivia preocupada com as histórias de minha casa (professora G- memória educativa).

Em se tratando de memória entendida como "resíduo das experiências estruturantes da primeira infância" (Rudge,1999), Freud utiliza duas abordagens diferentes. A primeira abordagem, de inspiração neurofisiológica, apresenta os traços mnêmicos, que se refere tanto a registro psíquico quanto a registro neurológico. Na esfera do psíquico, “ele é traço de impressão e não de sensação ou de estímulo". Na ordem neurológica ,“ele depende da resistência oferecida pelas barreiras de contato entre os neurônios" (Garcia-Rosa, 2002).

$\mathrm{Na}$ entrevista, podemos confrontar algumas situações.

Eu não era feliz na escola, não tinha amigos, me isolava e me sentia sozinha. Talvez por ser tímida e reservada. Era como se uma câmera estivesse me filmando o tempo inteiro, medo de decepcionar e de confiar nas pessoas. Vivia com a testa franzida...e ao mesmo tempo achava que tinha que me comportar e ser uma menininha educada ao extremo. Percebo que até hoje me cobro e sou muito sozinha, não gosto muito de gente. Acho que foram as vivências que tive na infância, a minha criação, elas me constituíram e continuam em mim como marca da minha personalidade (professora $B$ - entrevista).

No entanto, Ferretti (2004) afirma que se trata de reformulações, reedições, retomada de acontecimentos ocorridos na infância. Essa é concepção importante trazida pela psicanálise às concepções sobre o tempo, sobre a memória, sobre o sentido dos acontecimentos. A temporalidade retroativa pressupõe temporalidade lógica, não cronológica: o passado é revisitado não porque se volta cronologicamente a ele, mas porque há uma reformulação ou ratificação dele (p.95). 
A constituição do infantil é marcada na escrita das memórias e nas falas dos sujeitos que comparecem e se inscrevem - laços cheios de significados que repercutem o ser professor. Parafraseando Gaulejac, “somos história de outras histórias”. E a psicanálise é norteadora sobre a constituição do sujeito na relação com o Outro.

Hannah Arendt no livro “A condição humana” de 1958, aponta que não somos autores de nossa vida, história. O indivíduo não é seu próprio criador. Ele é condicionado por um conjunto de elementos que contribuem para sua fabricação e sua subjugação. Desse modo, a psicanálise mostra que somos resultado e expressão de nossa história de vida. Não somos autores nem senhores de nossa história, mas efeitos dela (CHAUÍ, 2000).

Um momento na realização do sociopsicodrama repercutiu em falas dos relatos das memórias educativas. Uma chamou a atenção: "Engraçado que essa história de escola me lembra pessoas [...] a memória que eu tenho dessa escola é afetiva gigantesca! ”. Ressalta que as memórias educativas remetem muito mais à pessoas e sentimentos do que ao conteúdo ministrado em sala de aula. Outro depoimento em que outra professora diz: "Eu lembro das minhas professoras com muito carinho" reforça a ideia anterior.

Em um dos momentos do sociopsicodrama, foi pedido que voltem a mão direita ao "coração" para buscar o afeto, o sentimento que a memória evocada traz, e nomear o que traduz aquela memória, como título. Os títulos foram: desconfiança, saudade, felicidade, nostalgia, sinceridade, indignação, incompletude, segurança, tristeza, prazer e madrinhagem (até palavras foram criadas). Ao falar o nome do afeto, elas iam se distribuindo no espaço da roda formada por todas de pé. Em seguida sem sair do lugar, "tocavam os afetos" mais próximos. O professor Paulo comenta que "essas são as nossas conexões inconscientes, eu diria mais, até estão descobrindo isso, até neurais elas estão com esse tipo de relação". Em seguida, sugere que façam uma pose, imitando estátuas, em relação aos sentimentos que se conectaram. Voltando à posição inicial de roda formada ombro a ombro, pede que falem uma palavra sobre a vivência 
do dia. Surgem as palavras fé, satisfação, diferente, prazer, saudade, amor, resiliência, compreensão, delicadeza, liberdade.

De acordo com Blanchard- Laville (2005, p.18), a psicanálise não é senão um ponto de vista, mas aquele que ela escolhe por lhe parecer o mais fecundo e o mais acertado; afirma ainda que o que descobre nos outros é também sua própria realidade, bem como a de todos nós. Não são “casos” que são estudados, são momentos de vida, sempre em situação pedagógica, mas singularmente pessoais.

Minha entrada na escola foi aos dois anos na creche, como cresci numa cidade de interior era o único meio de socialização. Não me lembro muito dessa época, apenas da minha mochila que eu realmente adorava (professora D- memória educativa).

Minha trajetória se iniciou no jardim. Naquela época tinha apenas três anos de idade e, conforme relatos da minha mãe, ingressava animada para conhecer novas crianças e, sobretudo, brincar (professora F-memória educativa).

Os excertos da memória da professora mostram o quanto a escola tem significado e importância na de criação de laços de que nos constituímos contemplando um infantil que recorrentemente comparece.

\begin{abstract}
Minha alfabetizadora era paciente, tinha os cabelos anelados, era meio gordinha. A da terceira série era meiga, cabelo de laquê, baixinha, miúda e super carinhosa. A da quarta série era meio de mal com a vida. Sempre de mau humor e dando uns foras nos meninos...meus professores sempre foram meus exemplos, recebi aula de formação humana: ser é melhor e mais importante do que ter. E essa filosofia eu carrego comigo... minha querida professora nos_ensinou muito de português, mas nos ensinou a ser feliz! (professora H- memória educativa).
\end{abstract}

Lajonquière (2010) ressalta a importância do desejo de aprender. "Reconheçamos à criança esse desejo...e qualquer método lhe será bom". A educação de uma criança é causada pelo desejo impossível de ser reabsorvido simbolicamente.

De qualquer modo, há um outro efeito da linguagem, que é a escrita (Lacan, 1985, p.63). Nesse sentido, o sujeito encontra na escrita um meio propício e adequado para expurgar a dor e conservar as alegrias, como sustenta Barros (2007). Interessante pensar na apropriação de 
uma história e fatos acontecidos advindo de laços constituídos do Outro, em que o sujeito da enunciação, do inconsciente, comparece, produzindo efeitos para além do ser.

Almeida (2002) afirma que o professor passou muito tempo em contato com seus professores enquanto aluno, assim como com os colegas, conteúdos e rituais específicos que moldaram o seu processo de ensino-aprendizagem e a sua singularidade como docente. O resgate dessa memória educativa promove reflexão da identidade, possibilitando um autoconhecimento de maneira que também se torna possível uma ressignificação e reestruturação da própria história individual e das relações sociais que fazem parte do cotidiano do sujeito.

\subsection{Processos identificatórios e transferenciais}

Estudei com a tia ... que até hoje faz parte da minha vida e me lembro com muito carinho, lembro de passar bons momentos com ela. (professora D- memória educativa).

Ao abordar o processo identitário, Mezan (1988, p.254) afirma que a ideia primordial é a de que o sujeito é constituído por um conjunto de identificações com o Outro, em que a identidade remete à sensação subjetiva de que "eu sou eu", isto é, de que algo permanente subjaz os diversos momentos de minha existência. Desse modo, as identidades podem servir de referência aos movimentos pulsionais e a elementos de reconhecimento que possam permitir, concomitantemente, afirmar tanto o que é singular em nós, como nossas diferenças. Em outra vertente, o outro pode representar um interlocutor privilegiado, o qual nos coloca diante da familiaridade imprescindível para que consigamos fazer circular nossas fantasias e a realização dos nossos desejos.

Adorava ir para escola, mas tinha medo da diretora, que parecia uma bruxa... A estagiária deu uma aula do sistema solar que nunca consegui esquecer... No final do ano estávamos ansiosos, pois iríamos para o quarto ano e a professora era muito brava. Mas para nossa surpresa, ela foi inesquecível... Meu irmão brigou na escola, fiquei péssima. A diretora me chamou na sala dela para falar do meu irmão, todos queriam saber o motivo de ter sido chamada e logo pela diretora temida, achei que isso manchou minha vida escolar... A escola sempre foi prazerosa e algo significativo na minha vida, cresci rodeada de professores e sempre soube valorizar e respeitar a todos... Momentos marcantes dessa época foram as primeiras paixões, a primeira 
cola que passei, a importância de escrever de caneta, tentei fugir da escola por um buraco na grade, fui a única que não conseguiu e acabei na direção... Fui madrinha da turminha de formandos do jardim, era uma honra. Me senti muito importante... A escola volta para minha vida, mas por outra perspectiva, a de mãe... Ao chegar a uma sala de aula e ver todos os alunos esperando algo de você é muito significativo e prazeroso. Hoje ser professora é uma opção, é aprender sempre ( professora Dmemória educativa).

$\mathrm{Na}$ escrita da memória da professora $\mathrm{D}$, é possível identificar o quanto a transferência e a identificação se fazem presentes na dimensão de realização. Segundo Lacan (1964/1990,p.139) a transferência é a colocação em ato da realidade do inconsciente. Faz sentido, segundo Almeida (2004), crer que a maneira como cada um de nós ensina está diretamente dependente do que somos como sujeitos.

As experiências vividas e inscritas proporcionam a constituição do sujeito cheio de significados em sua singularidade. Percheberty $(2011$, p.71) salienta que é a relação com o infantil e com o inconsciente que é mobilizada no desejo de aprender e transmitir.

Quando escrevemos, nos distanciamos de nós mesmos. Precisamos criar um afastamento ótimo para que, no espaço em branco do papel, deixemos as marcas que nos afetam. Algumas vezes queremos dividir com o outro, enviar uma mensagem que será lida por alguém. Muitas vezes escrevemos para colocar ordem em nossos pensamentos, em nossas paixões: não queremos que ninguém leia nossos diários. Quando a eles retornamos, lemos confissões sobrecarregadas de afetos que hoje estão esmaecidos na memória (BARROS,2007).

Logo no primeiro dia de aula a professora mandou um dever de casa. E eu, acostumada com minhas férias, esqueci-me de fazer. Fui severamente repreendida com acusações de ser preguiçosa. Meus olhos se encheram de lágrimas e eu, com minha cabecinha infantil, não entendia por que eu era preguiçosa se eu apenas tinha brincado. Nunca mais esqueci minha tarefa de casa... A professora perdeu um filho com leucemia e isso me marcou muito... E eu, mais vez, repito: acho que o que faço em sala conscientemente agora percebo que muito me espelho em meus queridos professores... Aprendi com minha mãe, que foi minha professora na faculdade, em casa e na vida. Ela é pedagoga e ótima professora. Idealista. Ah! meu pai também foi meu professor. Da sabedoria. Da escrita (professora H-memória educativa).

A professora $\mathrm{H}$ expõe momentos marcantes e finaliza afirmando se espelhar em seus professores e pais como forma de identificação. Na obra de Freud, segundo Laplanche e Pontalis (2001), o conceito de identificação assumiu progressivamente o valor central, que faz 
dela mais do que um mecanismo psicológico entre outros, a operação pela qual o sujeito humano se constitui. Essa evolução tem relação direta principalmente com a colocação em primeiro plano do complexo de Édipo em seus efeitos estruturais (p.227).

Tomei a decisão de ser professora, sem perceber, não era a princípio meu sonho, quando senti já estava sendo professora. Viemos eu e minha família de Minas Gerais para Brasília, onde o projeto da empresa dos meus pais participou de uma exposição no pavilhão do Parque da Cidade, expondo arranjos florais. Eu dava oficina de arranjos para fazer decoração. Com paisagismo nas plantas naturais e montagens. Formei 97 profissionais em paisagismo e me identifiquei com o ser professor. Decidi fazer Pedagogia (professora F- entrevista).

De acordo com a narrativa da professora, sua identificação se deu no estar como professora e na realização de uma transmissão. A personalidade se constitui e se diferencia por uma série de identificações. É processo psicológico pelo qual o sujeito assimila um aspecto, uma propriedade, um atributo do outro e se transforma, total ou parcialmente confirma Laplanche e Pontalis. Ainda sobre as identificações, Blanchard-Laville (2005) pontua que não é simples imitação, mas movimento de apropriação, obedece a um fim inconsciente, constitui um modo de expressão do fantasma inconsciente.

\begin{abstract}
Nessa fase escolar sempre era muito elogiada pelas professoras e tinha um desempenho acima da média, aprendia muito rápido e concluía as minhas atividades rapidamente, então acabava ajudando os coleguinhas a fazer as atividades (talvez tenha sido nesses momentos que surgiu a vocação para professora)... Lembro que deixei para fazer a inscrição no último dia, fui à casa de uma amiga e ela me convenceu a marcar a mesma opção que ela: pedagogia. No momento fiquei meio indecisa porque nessa época gostava de psicologia e direito, mas acabei cedendo e fazendo a escolha que mudaria não só a minha vida, mais a maneira de eu enxergar o mundo... Com a primeira experiência (estágio), eu tive a certeza de que estava no curso certo e que a sala de aula era realmente o meu lugar (professora E-memória educativa).
\end{abstract}

As concepções sobre o cuidado com o outro se refletem em minha prática, aquilo que vivencio, a acolhida... se a criança é assistida, ela aprende a ter outro olhar. Isso é muito bom porque é esse olhar dentro de mim que eu não consigo desvencilhar. O ser subjetivo da criança, o desenvolvimento dela e a minha prática pedagógica. Isso é fantástico! Né? (professora F- entrevista).

Bertolozzi (2006) afirma que o professor, confrontando-se com seu próprio dizer, será capaz de sair do lugar das certezas cristalizadas possibilitando que perguntas e questões apareçam, desconstruindo sua ilusão de onipotência e completude. Instalando, assim, a falta colocando-os numa perspectiva do possível e não do idealizado, na dimensão simbólica. 
Do ponto de vista freudiano, a atividade profissional constitui fonte de satisfação especial se for livremente escolhida. Sendo assim, percebemos certa idealização em torno do ambiente escolar e do ofício ser professor. Nesse cenário de realização remetendo identificações e transferências alguns relatos das professoras se presentificam:

Utilizávamos cartilha e muitos estímulos visuais no quadro negro e paredes da sala de aula. Foi no prezinho que recebi minha primeira fitinha, fiquei muito orgulhosa e minha família também. Nessa época, aprendi muito, fiz muita traquinagem, bagunça e foram muitas as idas para a direção, no entanto só levo boas lembranças e muito prazer em estar na escola... Minhas maiores dificuldades foram matemática e inglês, as professoras sabiam muito, mas não conseguiam passar o conteúdo para os alunos... Descobri que, se quisermos nos aprofundar nos conteúdos dados, temos que correr atrás... A matemática voltava a assustar com o estudo de estatística, foi aí que fiz as pazes e percebi que era boa, só era preciso dedicação e empenho. Concluí que o que eu quisesse aprender eu conseguiria. Senti muito orgulho de mim (professora C-memória educativa).

No jardim e no pré cursei com a mesma professora, calma, paciente, extremamente organizada, séria e afetiva sem exageros... As professoras nos passavam segurança, apropriação do conteúdo trabalhado e sempre com atividades diversificadas, trabalhos em grupo e de pesquisa e por vezes permeados de jogos e brincadeiras... Tinha uma professora muito competente, mas exigente, que provocava a gente, irritando-nos com a intenção de nos tirar da zona de conforto (professora $C$ memória educativa).

Aqui vale recordar o vínculo didático defendido por Claudine Blanchard-Laville ao reiterar que a relação com o saber matemático tem firmes raízes na história pessoal de cada um, seja aluno ou professor. Além disso, trata-se de processo cuja existência só é identificável no interior da dinâmica relacional entre os sujeitos, e da dinâmica transferencial mantida pelos parceiros entre os quais ela tem de se manifestar. Nenhum professor o é em isolamento, definindo-se sempre, imaginariamente, pela presença dos alunos que vieram e dos alunos que virão, do mesmo modo como nenhum aluno existe em isolamento: ele está sempre na presença imaginária do professor que vai arguí-lo ou do examinador que vai controlá-lo (BLANCHARDLAVILLE,2005, p.139).

Importante ressaltar a interferência das vivências sociopsicodramáticas que se fizeram fundantes na análise de dados em que o dispositivo da memória educativa, juntamente com a vivência, fez que percebêssemos os processos de identificação e transferência. Aí, o vínculo 
didático reforça o ser infantil e o sujeito em sua singularidade. Podemos observar/ analisar pelo sociopsicodrama a seguir:

O sociopsicodrama tem início com a leitura do texto "Idade Escolar Normal", do livro "Volta ao Lar", de John Bradshaw (1995), tese de doutorado de neopsicanalista. Nesse dia, o objetivo focou no campo da infância, da pré-adolescência e da adolescência.

1. Você costuma se comparar com outras pessoas e sempre se sente inferior?

2. Você gostaria de ter mais amigos de ambos os sexos?

3. Costuma sentir-se pouco à vontade em situações sociais?

4. Sente-se pouco à vontade como parte de um grupo? $4 \mathrm{~A}$. Sente-se melhor quando está sozinho?

5. Às vezes dizem que você é muito competitiva, sente que precisa ganhar?

6. Frequentemente tem conflitos com seus companheiros de trabalho? 6 A. E com as pessoas da família?

7. Em uma negociação você cede completamente? 7 A. Insiste em fazer as coisas do seu modo?

8. Orgulha-se de ser rígido e literal seguindo a lei ao pé da letra?

9. Você sempre procrastina as coisas?

10. Tem dificuldade em terminar as coisas?

11. Acha que devia fazer as coisas sem nenhuma instrução?

12. Tem muito medo de cometer erros? 12 A. Sente-se extremamente humilhada quando é obrigada a constatar os próprios erros?

13. Fica zangada com frequência e critica muito as outras pessoas?

14. É deficiente nas aptidões básicas da vida? 14 A. Ler, falar, ou escrever gramaticalmente ou fazer cálculos matemáticos básicos? 
15. Passa muito tempo analisando obcecada por alguma coisa que disseram ao seu respeito?

16. Sente-se feia e inferior? 16 A. Se sim, tenta disfarçar isso com roupas, coisas, dinheiro, maquiagem?

17. Costuma mentir para você mesma e para os outros com frequência?

18. Acredita que, por melhor que você faça, nunca está fazendo a coisa certa?

A leitura das questões foi feita em voz alta, porém as respostas deveriam ser individuais preenchendo o questionário que acompanhava o texto, buscando responder com sim ou não às questões, sem fazer uso do talvez.

No texto o autor afirma que se uma das questões teve sim como resposta, provavelmente o respondente teve sua criança ferida na idade escolar. E há vários graus de ferimento. Quanto mais perguntas sins, mais a criança está ferida. Após a leitura dessa afirmação, o grupo de professoras se mostra agitado.

O próximo passo foi compartilhar, por quem se sentiu à vontade, as respostas às questões apresentadas. O professor, como diretor de cena, destaca que seu interesse é especialmente nas cenas lembradas, que tenham acontecido em ambiente escolar e que compõem a visão que o sujeito tem de si. Ele lembra que todos têm na memória professores marcantes, fossem eles "bons" ou "ruins" e que talvez algumas das questões acima remetessem à memória de certos momentos. 
Em seguida foi feita a contagem das professoras que responderam sim a cada questão, para que depois fossem vistos os itens comuns. Abaixo o quadro com o total de sim dado para cada questão:

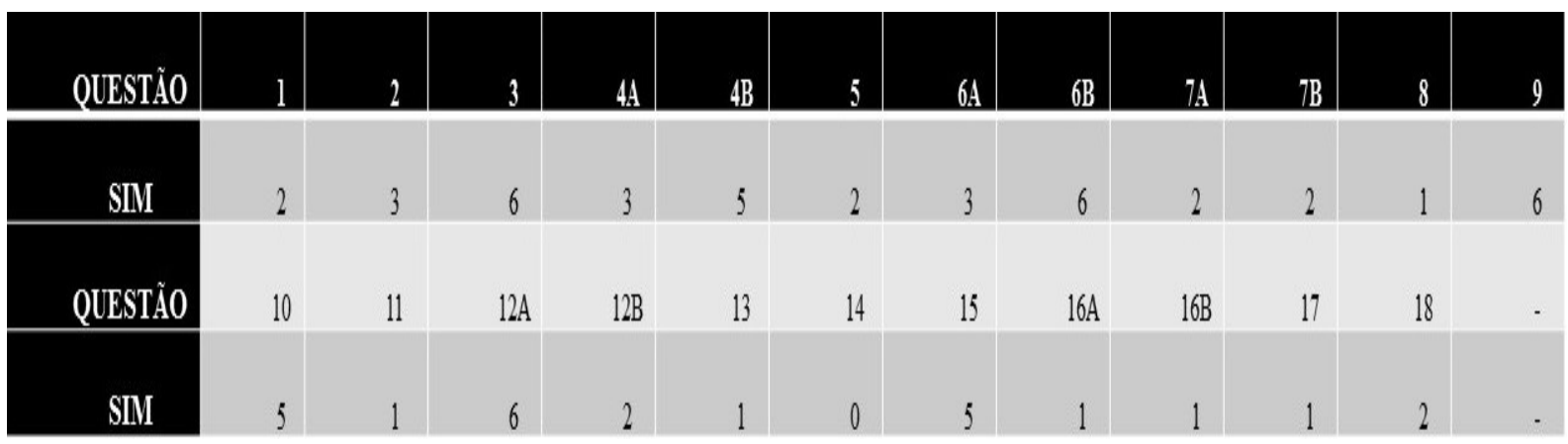

Quadro 4 - Questões do texto idade escolar normal

Fonte: a autora

Nesse encontro havia 15 professoras presentes. Nenhuma professora respondeu sim à questão 14, apontando que o grupo se percebe eficiente nas aptidões básicas da vida. As questões 3, 6A, 9 e 12 receberam o maior número de sim. Relembrando e analisando as questões citadas acima:

A questão 3 é a primeira que recebe o maior número de sim. A pergunta é: Costuma sentir-se pouco à vontade em situações sociais? Ainda que as questões tenham sido respondidas por professoras ativas em cujo cotidiano trabalham em grupo, seja liderando um, quando ministra aulas, por exemplo, seja fazendo parte, quando está num grupo de professores. Há ainda um desconforto em estar em situações sociais, ou seja, nem a prática, o envolvimento e a vida escolar, tantas situações sociais as fazem ter tranquilidade em momentos assim. É possível ainda supor que o mal-estar tenha se dado em algum momento da vida escolar como o próprio autor do texto afirma.

A segunda questão a que mais professoras responderam sim foi a 6A: Frequentemente tem conflitos com seus companheiros de trabalho? $6 A$ - E com as pessoas da família? 
Importante que Freud observa nos estudos clínicos as relações do paciente a família, ressaltando como os muitos conflitos que temos estão ligados à relação os familiares.

Na questão 9 - Você sempre procrastina as coisas? É possível pensar interferências e/ou consequências de uma vida escolar no âmbito do adiamento das atividades? Talvez as obrigações a nós repassadas desde o início da vida escolar, como os deveres de casa, tenham nos feito perder o gosto pelo cumprimento das tarefas, seja por chegar a nós de modo a ser uma obrigação, seja por serem atividades sem sentido ou significado. De todo modo é possível supor que sim, a vivência escolar tenha nos deixado marcas que atualmente são reeditadas em nossa postura.

Outra questão a que o grupo respondeu sim é a 12 - Tem muito medo de cometer erros? Apesar de ser acompanhada da $12 \mathrm{~A}$ - Sente-se extremamente humilhada quando é obrigada a constatar os próprios erros? - não teve a mesma repercussão no grupo. Assim como na questão anterior é também possível traçar ligações do medo de errar com possíveis marcas deixadas pelas vivências escolares. Pergunta-se quem teve as atividades avaliativas corrigidas de caneta vermelha com $\mathrm{X}$ apontando respostas erradas e talvez ainda hoje sinta medo, desconforto ou mesmo pânico ao passar por avaliações? São marcas desse tipo que a vida, escolar ou não, nos deixa e nós as carregamos fazendo releituras das cenas e reconhecendo que também são momentos que nos constituem. Essa questão também suscitou como professora/pesquisadora lembranças de um momento como orientadora educacional quando da apresentação do plano de ação anual com todas as atividades a serem desenvolvidas na escola. Em certo ano a coordenadora dos Orientadores Educacionais passou para o setor responsável - Gerência de Orientação Educacional (GOE), a pedido deles os nossos planos de ação, que, corrigidos com marcações e vários comentários, causaram constrangimento. Muitas relataram que se sentiram como alunas nos anos escolares tendo que seguir um padrão pré-determinado, sendo, de certa 
maneira, julgadas pela maneira como se deu a correção, marcas constituintes recordadas e repetidas.

Ao indagar se alguma das questões do questionário remeteu a lembranças escolares, uma professora se manifesta. Para ela a primeira questão: você costuma se comparar com outras pessoas e sempre se sente inferior? A fez lembrar de um momento que vivenciou em sala de aula no seu terceiro ano, quando a professora regente decidiu falar das características dos alunos através da letra em sala de aula. A professora que faz esse relato se refere a essa atividade como "dinâmica muito infeliz" e continua falando em tom de deboche que na avaliação da sua exprofessora ela tinha complexo de inferioridade e complementa "isso, numa turma de adolescentes, é péssimo, é a pior coisa que você pode fazer". O professor Paulo Bareicha interfere após a fala da professora para explicar que o complexo de inferioridade tem conceito diferente do que aprendemos no senso comum. Significa que, quando se tem alguma característica que o torna inferior ao outro, você a usa como motivação, alavanca para ser tão bom ou melhor que os outros que não sofrem com tal inferioridade. Em seguida a professora que fez o relato afirma que "de certa forma foi o que ela fez", referindo-se ao conceito de complexo de inferioridade.

O próximo relato é de outra participante que se lembra de uma professora de matemática que teve na terceira e quarta série a quem tinha horror. Conta uma prática que a professora tinha em sala: cobrar a tabuada dos alunos de trás para a frente. Os alunos eram colocados em pé na frente da turma com os braços para trás. Em uma vez que foi cobrada a tabuada do oito, a professora conta que "engasgou, já não sabia mais" e que a "professora começou a me achincalhar. Como assim? Não sai nada dessa cara vermelha? Dessa cara bolachuda? Dessa cara de tomate? [...] Ela vinha e apertava assim - ela aperta as próprias bochechas - vai você não consegue falar? E as minhas bochechas ficavam mais vermelhas - E a professora continua - Olha que você vai ter um D de novo, você vai ficar de recuperação. E cita várias outras 
passagens com essa professora [...] eu sempre tirava D, "D" de doido. Essa mulher era doida, né?"

Muitos colegas se tornaram professores. Eu me tornei. E faço questão que meus alunos saibam. Aprendam. Gerem significados como eu fiz. E hoje percebo que esses professores tão especiais que hoje são nossos amigos nos ofereceram este quesito tão importante: a dedicação ao que fazem em na profissão. Acho que marcou em nossa turma pois todos em nossos caminhos buscamos ser pessoas que fazem bem o que escolheram. Escolhi já com 13 ou 14 anos fazer escola normal. E passei na prova. Fiz três anos na Escola Normal de Brasília. Quando fiz pedagogia, eu já havia aprendido o doce mais doce que batata doce que foram as didáticas. E na faculdade aprendi a polir meus conhecimentos. Aprendi a entender quais caminhos eu podia escolher para minha profissão (professora H-memória educativa).

Ano passado pude lecionar na mesma escola que estudei da $1^{a} \grave{a}^{5}{ }^{a}$ série (a série em que reprovei por falta). Minha mãe foi pegar meu boletim, lembro que chorei muito e ela me perguntou se eu queria ficar na mesma escola ou mudar. Decidi na hora mudar, pois, se não me engano, fui a única da sala que reprovou (professora $I$. memória educativa).

\title{
5.3. Mal-estar do professor: da inscrição à elaboração
}

\begin{abstract}
Ela me dava um certo medo, ela não sorria, não era carinhosa, era seca.... Quando iniciei o primeiro ano primário, minha professora era magra, elegante, amorosa, gostava dela.... De todas as memórias, as mais importantes, são os olhares atravessados que recebi de docentes que passaram por mim. O que fiz com eles? Eu os deixei passar... pois o que aprendi de mais significativo é como eu olharia para as pessoas ao meu redor, principalmente as crianças que, como eu, esperam um olhar de acolhimento para suas angústias, esperam um colo para o mundo que carregam. Todas as vivências que tive, das mais dolorosas às mais suaves, me ajudaram a construir o que sou, uma professora que olha para a criança e busca um vínculo de ligação com aquele universo de possibilidades (professora $G$ - memória educativa).
\end{abstract}

Cifali (2009) diz que o único meio de não ceder à incompreensão violenta que suscita um projeto frustrado é ser capaz, talvez, de admitir que, de saída, há um desconhecimento no encontro que se tece entre a criança e aqueles que a engendraram, e aceitar que um saber se constrói no dia a dia, com o reconhecimento cada vez mais experimentado dessa criança como sujeito, não como um objeto de medidas racionalizadas, mesmo em nome da psicanálise. Por isso ninguém reduziria, no futuro, esse impossível. Nosso progresso solitário seria o de ouvi-lo não como uma infelicidade, mas como constitutivo de nossa relação com o outro-sujeito. 
Apaixonei-me sonhar com as palavras. Mais não era feliz. Não lembro de momento brincante algum. Eu fui menina assustada e sempre preocupada com as notas. Em casa, muita exigência. Eu não podia falhar. Estudava muito... Poderia contar do tamanho da escola, do caminho tracejado de perguntas de casa à escola, do olhar de minha bisavó a orar até que a minha sombra soprasse ao longe...Eu pensando. Pensar o pensamento! Estudar era saber pensar! Sem meu professor e terminando o ensino fundamental, deixei de viver bem. Mergulhei novamente no medo. Haja desespero. Ensino médio era uma tortura...Estive toda inteira no ser: o ar e os sonhos. Etérea (professora B-memória educativa).

Em complementaridade, ao participar da entrevista, a professora B relata que teve uma professora muito amarga, que tinha um olhar de racionalidade e não tinha sensibilidade. Lembra que certo dia essa professora a expôs perante toda a turma a deixando de castigo. Sofreu muito. Foi difícil suportar e ressignificar.

Todavia, os mal-entendidos, como aponta Blanchard-Laville (2005, p.140), são inerentes ao vínculo didático, mas talvez não seja útil permitir que se cristalizem. Não podemos nos esquecer de que essas pessoas são sujeitos com uma história singular de sua relação com o saber, ainda que todas as aparências tendam a uma forma de normalização por meio da socialização profissional, que é a propósito delicada, e pelo jogo da institucionalização.

\footnotetext{
Nessa época, os professores já não se importavam muito com os alunos, havia certo descaso com a nossa aprendizagem, isso despertou em mim uma maior autonomia nos estudos e foi então que eu descobri que tinha mais facilidade e prazer em estudar as ciências humanas do que as ciências exatas (professora E-memória educativa).
}

De acordo com as narrativas dos professores em que circunda a inscrição do mal-estar e sua elaboração, interessante visitar a psicanálise onde Freud (1920) em "Além do princípio do prazer", introduz a noção de pulsão de morte. Trata-se da morte do próprio sujeito e não do assassinato de um outro. Bonfim (2015) salienta que, quando o professor é agressivo com o aluno, antes, ele mesmo já está vivenciando um processo de adoecimento e sofrimento psíquicos, representando processo de autodestruição.

Ademais complementam pelo sociopsicodrama alguns momentos que simbolizam a inscrição. Em uma oficina, o professor Paulo Bareicha começa contando uma memória dele 
que se referia ao caminho que fazia para ir à escola. Depois uma professora decide compartilhar uma memória dela. Apesar de não lembrar o nome da professora que ela teve, lembra que ela jogava nos alunos giz e às vezes até o apagador: "Ela - a professora - era louca, mas não lembro o nome dela". Outra professora retoma dizendo que antes ela não sabia ler e que na sala onde estudava uma mesma professora dava aula para três séries diferentes, todas juntas. Sua professora dividia o quadro em três partes e assim separava o conteúdo de cada série dada no dia. E, nessa memória, lembra que copiava do quadro todas as partes. O que ficou marcado para ela é que a escola de Goiás, onde essa cena ocorreu, deixava a desejar porque ela passou sem saber ler. E lembra que, quando estudava lá, havia apenas duas salas, mas que numa visita recente à escola surpreendeu-se com a imensidão do colégio. Em seguida outra professora diz: "Lembrei de uma professora aqui agora. Ela era pequeninha e tinha um cabelo armado, um dia ela foi de bobs".

Importante ressaltar que o sociopsicodrama, como assevera Muñoz (2013, p.500), se apresenta como necessário no exercício do papel docente: compartilhar as coisas que angustiam, preocupam, assumindo a situação de maneira coletiva; negociar com todos os envolvidos; e buscar o sentido da formação necessária são primordiais.

Em complementaridade, do ponto de vista freudiano nos escritos em "Análise terminável e interminável", o método psicanalítico não busca apenas um objeto determinado ou algo a ser concluído, pois se caracteriza como um ato processual, uma contínua abertura para o devir.

Atendendo a demanda do grupo de professoras, o último sociopsicodrama do grupo matutino foi reestruturado pela percepção de um mal-estar em que era perceptível uma inscrição necessitando de elaboração. Percebemos que não temos controle sobre o que planejamos e isso permeia também a realidade da sala de aula. Somos sujeitos faltantes com nossa subjetividade permeada pelo infantil. 
O sociopsicodrama se iniciou com a direção do professor Paulo Bareicha sugerindo momentos de trocas com utilização de instrumentos como lantejoulas, botões, pequenas peças que simbolizavam e remetiam a algo.

1. Bom-dia!

2. Gratidão

3. Perdão- pedir ou dar perdão

4. História de vida- compartilhar

Cada professora recebeu a mesma quantidade de pecinhas que possuíam o significado de bom-dia, gratidão, perdão ou história de vida e foi solicitado que distribuíssem entre si. No final todas contaram com quantas cada uma ficou e sua repercussão no sentido do significado. Entre elas foram dando as explicações.... Dei a gratidão para minha colega, pois ela sempre me ajuda nos planejamentos, distribuí bom-dia a todos e fiquei sem nenhum, aproveitei para pedir perdão, recebi muita gratidão, minha história de vida guardei comigo e assim foram tecendo comentários.

O professor percebeu que havia uma demanda maior no grupo, um tom de segredo de "diário". Perguntou o que estava acontecendo e foi perceptível o mal-estar. Pediu que todas se sentassem e dissessem o que estavam sentindo.

Sendo assim, surgiu no grupo o comentário com relação à assembleia dos professores, que, em coordenação, haviam decidido paralisar para que todas participassem. No dia da assembleia apenas algumas foram e o grupo se sentiu dividido, pois onde se é tomada uma decisão e algumas não cumprem, surgiu o mal-estar no sentido de luta da classe, quando são um grupo e precisam se fortalecer. No momento da fala de quem tinha comparecido à assembleia, muitas se sentiram no direito de se defender e explicar o motivo de não ter comparecido. Tal como esse argumento e outros: estava indo com outra colega de carro e meu carro é preto igual ao Uber. Estava tendo uma manifestação dos taxistas que depredavam os 
carros de quem era Uber e, como estava próximo ao local da assembleia, preferi ir embora com medo de retaliação. Voltamos para a escola e cumprimos nosso horário, não fomos para casa... Já eu preferi elaborar minha prova na escola, estou muito atrasada com várias demandas...

Diante das falas, o professor diretor de cena decidiu fazer um axiodrama (método sociátrico vindo do sociodrama, mas que emite anseios morais e valores). Constituiu a seguinte cena representada (com cadeiras)

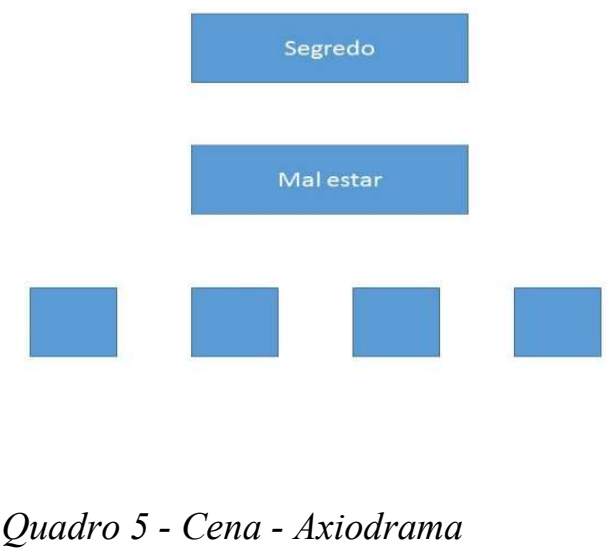

Fonte: a autora

Ao final, cada uma ia se colocando como no lugar do mal-estar, assembleia, uma foi o segredo velado e percebemos que uma viu a cena toda de fora e não quis participar. Disse não se sentir bem vivendo esses momentos. Foi perceptível o fio de tensão, as expressões de desconforto, julgamento, afirmação, algumas na fala demonstraram revolta pelo acontecido e algumas possuíam a necessidade de se defender em todos os momentos da condução do axiodrama. Foi interessante contemplar, através das falas, o desvelar do segredo. Todas se sentiam incomodadas por alguma questão, mas não tinham tido oportunidade de se expressar e reelaborar o momento. Questões como essa remetem a posturas políticas, posições de valores, morais e sociais que causam transtornos quando não resolvidas. A solução do problema se deu vivenciando a situação e se colocando no lugar do outro. O desabafo é muito importante assim 
como se sentir escutado nos anseios. Foi muito interessante. Mesmo não inserida na proposta do curso, certamente vivenciamos um dos fundamentos da psicanálise- a de que não controlamos tudo.

Reiventar o cotidiano escolar significa "ofertar aos alunos cultura e não migalhas pedagógicas embrulhadas em bondade psicoafetiva, acertando eticamente nossas contas com o passado que nos assujeita" (LAJONQUIÈRE, 1996, p. 36).

A dinâmica vivida foi encerrada com a pergunta: como cada um entendeu esse momento? Cada um tirou para si conclusões.

Os mal-entendidos são inerentes a toda forma de vínculo, estando, pois, também na base do vínculo didático. Podem abrigar felizes surpresas que desvelam o não esperado ou o não entendido (BLANCHARD- LAVILLE,2005, p.177).

A reflexão trazida por Cifali vai de encontro à quando estamos educando, seja o aluno de qualquer nível de escolaridade, nos vemos nesse aluno como um espelho. E, por esse motivo, temos que fazer as pazes com a criança que está dentro de nós, para não virar acerto de contas.

Uma das especificidades dessa profissão reside no encontro com uma, com várias crianças, quer sejam de nossa carne quer não nos sejam nada, mas que nos olham num face a face inevitável. Aquele que suporta o ato de educar, certamente, já o afirmaram, não se confrontaria somente com a criança viva para a qual formula um projeto, mas também e, sobretudo com a criança que era, conforme uma lembrança idealizada que guarda - a criança "recalcada" que o inspira na maioria de suas reações. Quando usa meios que opõem a si mesmo, fixa-se neles mais do que crê nas suas próprias necessidades pulsionais, se bem que os justifique frequentemente com racionalizações: é para o teu bem. Este laço educativo não estaria isento de projeções imaginárias, de ilusões e exageros; nele dominam, soberanos, as compulsões inconscientes e os desejos insatisfeitos, uma história maquiada que não para de se repetir; todas 
as falsas razões do jogo do amor e do ódio com essas violências que não dizem seu nome. Os sentimentos estão lá onipresentes, escapam a uma lógica racional. O outro-criança acorda não mais o espírito científico que nele se encontra, mas as suas forças inconscientes. Como no sonho, a relação com a criança convoca as forças do avesso. Assim, necessitar-se-ia contar com aquele que diz educar cujo ato depende dele, um ser humano, um comum dos mortais. Sua subjetividade seria desde um bastião de resistência a um conhecimento da realidade. Tornaria do mesmo modo mais compreensível o fato que um desejo de lógica e que um amor à verdade sejam então mal-estares a preservar. (CIFALI, 1987, p. 128-129). 


\section{CONSIDERAÇÕES FINAIS}

O infantil, apesar de não ter sido conceituado na psicanálise pelos escritos de Freud, ocupa importante lugar no sentido constituinte de nossa subjetividade, como forma de

estrutura do psiquismo. No entanto, podemos compreender neste trabalho o quanto a concepção do infantil é primordial para o entendimento da questão de como o professor compreende o significado da dimensão do infantil em sua constituição subjetiva e as repercussões no ofício docente.

Realizamos um referencial teórico buscando situar o lugar do infantil perpassando pela busca do objetivo de compreender a dimensão do infantil na constituição da subjetividade de professores à luz da teoria psicanalítica, além dos objetivos específicos que foram: reconhecer que a dimensão do infantil ocupa lugar de centralidade na constituição da subjetividade docente com repercussões no processo educativo em sala de aula; identificar possíveis implicações da atuação do professor de educação das séries iniciais do ensino fundamental na constituição da subjetividade infantil; e articular o dispositivo da memória educativa em escrita e ação através do sociopsicodrama como alternativa metodológica de pesquisa. Essa retomada norteia nossa reflexão.

Ao deparar com o campo do infantil, recordamos Lajonquiére (1999), segundo o qual o conteúdo infantil são os restos primordiais que nos atravessam, nos constituem e movem nossas ações, nosso aprendizado e as nossas percepções do mundo. Esse olhar em nosso trabalho se implicou no sentido de concepções e conclusões.

Por outro lado, os relevantes dispositivos utilizados na pesquisa permitiram o resgate da memória, o desvelar pelas cenas constituídas e o ouvir-se pelos vários momentos reflexivos. Essa articulação de dispositivos metodológicos com o aporte da teoria psicanalítica tornou-se um diferencial. A constituição do infantil é marcante e visível na escrita das memórias. Marcas 
cheias de significados e que repercutem no dia a dia de sala de aula. Ao escrever a memória as professoras se viram como alunas e perceberam o olhar docente como importante no processo de constituição, remetendo o infantil para o centro da subjetividade. Interessante perceber as implicações da atuação das professoras que levam consigo momentos e/ou cenas se presentificando nos laços construídos e/ou (des)construídos com o aluno aprendente na sala de aula. Para alguns ficou clara a importância da relação professor-aluno e o quanto essa relação é regada de significados. "Todas as vivências que tive, das mais dolorosas às mais suaves, me ajudaram a construir o que sou” (professora G).

Nas avaliações realizadas pelas professoras em relação ao curso, alguns registros remeteram um significado imensurável como "as vezes o controle nos escapa e o invisível fala”. "Percebi o que fui e o que sou”. "Resgate de nossa própria construção como sujeito”. Acessar a memória de nosso processo educativo me fez perceber cada vez mais como a afetividade e a sensibilidade são importantes para o aprendizado e na relação professoraluno".

A ousadia de unir dois dispositivos metodológicos como a memória educativa e o sociopsicodrama nos surpreendeu como algo inédito e inovador, uma forma de referendar a pesquisa no sentido do aporte de escrita e ação, do corpo e da fala, do sentido e significado.

A proposta do curso utilizando as professoras como sujeitos de pesquisa foi ao encontro do questionamento de como o professor compreende o significado da dimensão do infantil e as possíveis repercussões. Na escrita da memória, nas falas e/ou expressões corporais durante o sociopsicodrama e na entrevista foi marcante o quanto percebiam as marcas deixadas em sua formação e o quanto reproduziam em sala ou se privavam de transmitir conhecimentos que foram negativos na trajetória de suas constituições. O infantil presente se manifesta de certa forma em sala de aula trazendo à tona a subjetividade de cada uma. 
Importante o reconhecimento do quanto esse olhar para si no sentido que temos um infantil que nos constitui e comparece. Algumas sinalizaram que ficaram atentas à prática na percepção desses possíveis acontecimentos.

Nesse sentido, compreender certas questões clareadas pelos saberes da psicanálise no movimento em busca de nova perspectiva que ainda preserve de modo indissociável a importância da vida infantil e da educação sobre o devir das crianças que estão sob a responsabilidade de adultos, importante lembrarmos o que diz Freud ao se referir às pesquisas de Charcot.

Charcot costumava olhar repetidamente as coisas que não compreendia, para aprofundar sua impressão delas dia a dia, até que subitamente a compreensão raiava nele...Podia-se ouvilo dizer que a maior satisfação humana era ver alguma coisa nova - isto é, reconhecê-la como nova; e insistia sobre a dificuldade e importância dessa espécie de "visão"...Ele se indagava por que as pessoas enxergavam apenas o que tinham aprendido a ver...” (Freud, 1892-1899 / 1996, p. 22).

Assim (in) concluindo, parafraseando a sabedoria de Charcot registrada por Freud, que, apesar das dificuldades, este trabalho possa provocar uma espécie de "visão" para além do que enxergamos e/ou aprendemos a ver sobre o infantil, constituição da subjetividade do professor, repercussões no cenário da sala de aula e laços com alunos: feitos, (des)feitos e/ou (re)feitos.

Leny Mrech em seus escritos afirma que a linguagem não é um simples instrumento que possa ser utilizado ao bel prazer do sujeito. Há algo do real que sempre escapa e retorna posteriormente.

Parafraseando Lacan, “o simbólico é uma defesa frente ao real. O importante é que cada sujeito encontre uma forma de lidar consigo mesmo e com o Outro, com a civilização".

Desse modo, na leitura das análises feitas, deparamos-nos com momentos de mal-estar/ frustação e, ao mesmo tempo, laços de pertencimento que clarificam as vicissitudes vividas no 
processo educativo. Toda essa vivência veio ao encontro da abordagem psicanalítica de que não somos donos de nossa morada e não controlamos tudo. Visto que nos constituímos de marcas, significados, onde o eu inconsciente é regado de momentos em que nos presentificamos.

Nessa interface de relações e inter-relações, buscamos em Moreno (1983) o entendimento de que a psicanálise foi construída para permitir palavras e suas associações, em seguida, para analisá-las e indiretamente estimar o comportamento que poderia encontrar-se atrás das mesmas. O psicodrama foi construído para permitir ação e produção de tal modo que se estudasse o comportamento em sua forma concreta. Em sentido amplo, é a produção total versus a análise total $(\mathrm{p}, 245)$.

Ao realizar esta pesquisa, percebemos pela escrita da memória educativa o quanto foi significativo o desvelar do infantil na constituição da subjetividade. A utilização de dispositivos vivenciais como o Sociopsicodrama complementaram a análise e reafirmaram que o que descrevemos em nosso caráter baseia-se nos traços mnêmicos. Além disso, as impressões que maior efeito causaram em nós, as de nossa primeira infância (FREUD,1900, p.520).

A guisa de conclusão trazemos que o infantil se presentifica emergindo no processo educativo pela via transferencial regada de marcas subjetivas. Onde buscamos em Safra (2001) que o princípio fundamental da Psicanálise é ser um processo investigativo e não conclusivo.

As teorias completas não caem do céu e com toda razão desconfiarão se alguém lhes apresentar, logo no início de suas observações, uma teoria sem falas, otimamente rematada. Tal teoria certamente só poderá ser filha de sua especulação e nunca fruto da pesquisa imparcial e desprevenida da realidade (FREUD,1910, p.36).

Pensamos que essas reflexões e discussões possam contribuir com as práticas formativas no espaço escolar ao provocar novas posturas em sala de aula, reconfigurando a relação entre o ensinar e o aprender, tornando assim, o espaço privilegiado para a compreensão do processo 
educativo por meio da escuta, do olhar e leitura das vivências compartilhadas referenciadas no aporte teórico da Psicanálise. 


\section{REFERÊNCIAS}

AGUIAR, F. Questões epistemológicas e metodológicas em psicanálise. J. Pscicanal, São Paulo, junho 2006.

AGUIAR, M. R. Violência na escola e sofrimento psiquico de professores: uma análise das práticas profissionais, de orientação psicanalítica. Dissertação de Mestrado. Brasília: Universidade Católica, 2014.

ALMEIDA, C. S.; KUPFER, M. C. A psicanálise e o trabalho com a criança-sujeito. 1. ed. Rio de Janeiro: Wak, 2011.

ALMEIDA, I. M. M. Z. P. Re-Significação do papel da Psicologia da Educação na Formação Continuada de Professores de Ciências e Matemática. Tese de Doutorado. Brasília: Universidade de Brasília, 2001.

ALMEIDA, I. M. M. Z. P. O lugar da memória educativa na formação dos professores: uma leitura psicanalítica. 1. ed. Curitiba: CRV, 2012.

ALMEIDA, I. M. M. Z. P. D. O Ser infante e o Ser professor na memória educativa escolar, In: COLOQUIO DO LEPSI IP/FE-USP. Proceedings online., 2002. Disponivel em: $<$ http://www.proceedings.scielo.br/scielo.php?script=sci_arttext\&pid=MSC00000000320020 00400011\&lng=en\&nrm=abn>. Acesso em: 29 nov. 2016.

ALMEIDA, I. M. M. Z. P. D. O lugar da memória de vivências na instituição escolar e a constituição da identidade do professor: (im) possíveis conexões com a psicanálise In: LEPSI IP/FE-USP 2004. proceedings.scielo, São Paulo, 2004. Disponivel em: $<$ http://www.proceedings.scielo.br/scielo.php?script=sci_arttext\&pid=MSC00000000320040 00100033\&lng=pt\&nrm=abn>. Acesso em: 29 nov. 2016.

ALMEIDA, I. M. M. Z. P. D. O lugar do gestor escolar no retrato do mal-estar contemporâneo na educação. $\quad$ scielo, $2011 . \quad$ Disponivel $<$ http://www.proceedings.scielo.br/scielo.php?script=sci_arttext\&pid=MSC00000000320120 00100020\&lng=en\&nrm=abn>. Acesso em: fevereiro 2016.

ALMEIDA, I. M. M. Z. P. D.; BAREICHA, P. S. D. A. Da escrita à inscrição: o lugar do infantil na constituição subjetiva do professor. Congres International Psychanalyse. Et Education, Paris, 2015.

ALMEIDA, S. F. C.. A ética do sujeito no campo educativo.. In: Psicologia escolar: ética e competências na formação e atuação profisssional. São Paulo: Alinea, 2003.

ALMEIDA, W. C. D. Psicoterapia aberta: o método do psicodrama, a fenomenologia e a psicanálise. São Paulo: Ágora, 2006.

ALVES, R. Conversas com quem gosta de ensinar. Campinas: Papirus, 2004. 
ANDRÉ, M.; GATTI, B. A relevância dos métodos de pesquisa qualitatica em educação no Brasil. In: WELLER, W.; PFAFF, N. Metodologia da pesquisa qualitativa na educação: teoria e prática. Petropolis: Vozes, 2010.

ARENDT, H. A Condição Humana. Rio de Janeiro: Forence Universitária, 2007.

BARDIN, L. Análise de Conteúdo. São Paulo: Edições 70, 2011.

BAREICHA, P. Psicodrama, teatro e educação: em busca de conexões. Linhas Críticas, v. 4, n. 7-8, 1999.

BAREICHA, P. Grupo sócio-educativo (GS) em uma perspectiva socionômica. In: GHESTIGALVÃO, I.; ROQUE , B. C. A aplicação da lei em uma perspectiva interprofissional: direito, psicologia, psiquiatria, serviço social e ciências sociais na prática jurisdicional. Petrópolis: Vozes, 2010.

BARROS, R. A Escrita Feminia. In: COSTA, A.; RINALDI, D. Escrita e Psicanálise. Rio de Janeiro: Cia de Freud, 2007. p. 173-184.

BASTOS, M. B. Inclusão escolar: inclusão dos professores? In: COLLI, F.; KUPFER, M. Travessias, inclusão escolar: a experiência do grupo Ponte- Pré Escola Terapêutica Lugar de Vida. São Paulo: Casa do Psicólogo, 2005.

BAUER, M. W.; GASKELL, G. Pesquisa qualitativa com texto, imagem e som: um manual prático. Petrópolis, RJ: VOZES, 2002.

BEILLEROT, J. L'analyse des pratiques professionelles: porquoi cette expression? In: BLANCHARD-LAVILLE, C.; FLABET, D. Analyser les pratiques profissionnelles. Paris: L'Harmattan, 2000.

BERGAMASCHI, R. I. Escrita Morte, Origem em Psicanálise. Dissertação de Mestrado. Florianópolis: Universidade Federal de Santa Catarina, 2006.

BIRMAN, J. Sujeito e estilo em psicanálise: sobre o indeterminismo da pulsão do discurso freudiano. São Paulo: Editora 34, 1997.

BLANCHARD-LAVILLE, C. Os professores entre o prazer e o sofrimento. São Paulo: Loyola, 2005.

BOMFIM, A. Profissão Docente - Laços de Pertencimentos e Identidade - Tese de Doutorado. Brasília: UnB, 2015.

CAPRA, F. A teia da vida. Uma nova compreensão científica dos sistemas vivos. São Paulo: Cultrix, 1996.

CARVALHO, J. S. F. Construtivismo uma pedagogia esquecida da escola. Porto Alegre: Artmed, 2001. 
CARVALHO, P. D. O. Uma investigação sobre a memória em Freud. Dissertação de Mestrado. Rio de Janeiro: PUC Pontifícia Universidade Católica, 2003.

CELES, L. Aspectos metodológicos da construção da psicanálise. Jornal de Estudos Psicodinâmicos, Brasília, 2000. 309-320.

CELES, L. Uma Herança quase-esquecida de Freud A Sexualidade Infantil e suas Injunções. Alter - Jornal de Estudos Psicanalíticos, v. 24, p. 65-82, 2005.

CHAUÍ, M. Convite à Filosofia. São Paulo: Ática, 2000.

CIFALI, M. Adresse à Michel de Certeau. In: Bloc Notes de la Psychanalyse. [S.1.]: [s.n.], v. VII, 1987. p. 128-129.

CIFALI, M. Ofício "impossível"? Uma piada inesgotável In Educação em Revista. scielo.br, 2009. Disponivel em: $<$ http://www.scielo.br/scielo.php?script=sci_arttext\&pid=S0102$46982009000100008 \& \operatorname{lng}=\mathrm{en} \& n r m=\mathrm{iso} \& \operatorname{lng}=\mathrm{pt}>$. Acesso em: 29 nov. 2016.

COIMBRA, J. C. Sobre o tempo e a memória na pscicanálise: O a posteriore em Freud e Lacan. Dissertação de Mestrado. Rio de Janeiro: Universidade Federal do Rio de Janeiro, 1997.

COSTA, G. Q. A criança, o adulto e o infantil na psicanálise. Laboratório de Psicanálise da UFC, Fortaleza, 06 fev. 2015. Disponivel em: <http://www.psicanalise.ufc.br/hotsite/pdf/Trabalhos/31.pdf $>$.

CRESWELL, J. W. Projeto de pesquisa. Métodos qualitativo, quantitativo e misto. 3. ed. Porto Alegre: Artmed, 2010.

CUKIER, R. Palavras de Jacob Levy Moreno vocabulário de citações do psicodrama, da psicoterapia de grupo, do sociodrama e da sociometria. São Paulo: Ágora, 2002.

DAVOLI, C. Psicodrama e sociodrama: uma caracterização. Revista Brasileira de Psicodrama, v. 2, n. 2, p. 25-28, 1990.

DEJOURS, C. Subjetividade, Trabalho e Ação. Revista Produção, São Paulo, p. 27-34, setembro-dezembro 2004.

FALKEMBACH, E. M. Diário de campo um instrumento de reflexão. contexto e educação, Ijuí, jul/set 1987. 19-24.

FERNANDES, C. M. Bereshit a constituição do aparelho psiquico. Disssertação de Mestrado. Rio de Janeiro: Pontifícia Universidade Católica do Rio de Janeiro, 2001.

FERREIRA, A. B. D. H. Dicionário Aurélio da Língua Portuguesa. Curitiba: Positivo, 2010. FERREIRA, N. S. C. Supervisão Educacional uma reflexão crítica. Petrópolis: Vozes, 2009. FERRETTI, M. O Infantil - Lacan e a Modernidade. Petópolis: Vozes, 2004. 
FIGUSCH, Z. O modelo contemporâneo de sociodrama brasileiro. In Sociodrama um método, diferentes procedimentos. São Paulo: Ágora, 2010.

FLEURY, H.; MARRA, M. Aplicações dos Métodos Sociátricos. São Paulo: Ágora, 2010.

FLORÊNCIO, S. Memória Educativa e Psicodrama como Dispositivos Pedagógicos Complementares - TCC. Brasília: UnB, 2015.

FRASER, M.; GONDIM, S. Da Fala do Outro ao Texto Negociado - Discussões Sobre a Entrevista na Pesquisa Qualitativa. Paidéia, Ribeirão Preto, Maio-Agosto 2004.

FREUD, S. [. Carta 52. In: Edição Standard das Obras Completas de Sigmund Freud. Rio de Janeiro: Imago, v. I, 1974. 285 p.

FREUD, S. Projeto para uma psicologia científica. In: Edição Standard Brasileira das Obras Psicológicas Completas de S Freud. Rio de Janeiro: Imago, v. I, [1895]1990.

FREUD, S. Além Do Princípio De Prazer. São Paulo: L\&PM Editores, [1920]2016.

FREUD, S. Freud On Line, 1899. Disponivel em: $<$ http://www.freudonline.com.br/livros/volume-03/vol-iii-15-lembrancas-encobridoras1899/>. Acesso em: 29 nov. 2016.

FREUD, S. A Interpretação dos Sonhos I. In: In Edição Standard Brasileira das Obras Pscológicas completas de S. Freud. Rio de Janeiro: Imago, v. 4 e 5, 1900.

FREUD, S. Consejos al médico em el tratamiento psicoanalítico. In: Obras Completas. 4. ed. Madrid: Biblioteca Nueva, v. II, 1912.

FREUD, S. Sobre o início do tratamento (Novas recomendações sobre a técnica da psicanálise I) in: Obras Completas. Riod de Janeiro: Imago, v. 12, 1913. 161-187 p.

FREUD, S. Prefácio à Juventude Desorientada, de Aichhorn. In: Edição Standard das Obras Psicológicas Completas de Sigmund Freud. Rio de Janeiro: Imago, v. 19, 1925.

FREUD, S. Cinco lições de Psicanálise. In Obras psicológicas completas de Sigmund Freud. Edição standard brasileira. Rio de Janeiro: Imago, v. VII, 1976[1910].

FREUD, S. Extratos dos documentos dirigidos a Fliess. In Edição Standard Brasileira das Obras Pscilógicas completas de S. Freud. Rio de Janeiro: Imago, v. 1, 1980. 243-380 p.

FREUD, S. Lembranças encobridoras. In Edição Standart Brasileira das obras psicológicas completas de S. Freud. Rio de Janeiro: Imago, v. 3, 1980. 333-358 p.

FREUD, S. Leonardo da Vinci e uma lembrança de sua infância. In Edição Standard Brasileira das Obras Pscilógicas completas de S. Freud. Rio de Janeiro: Imago, v. 11, 1980. 59-126 p. 
FREUD, S. Notas sobre o Bloco Mágico. In Edição Standard Brasileira das Obras Psicológicas completas de S. Freud. Rio de Janeiro: Imago, v. 19, 1980. 285-294 p.

FREUD, S. A Etiologia da Histeria. In: Edição Standart Brasileira obras psicológicas de Sigmund Freud. Rio de Janeiro: Imago, v. 3, 1996.

FREUD, S. A dinâmica da transferência. In Edição standard das obras psicológicas completas de Sigmund Freud. Rio de Janeiro: Imago, v. XII, 1996[1912].

GARCIA-ROZA, L. A. Introdução à Metapsicologia Freudiana 2. Rio de Janeiro: Jorge Zahar, 2002.

GIL, A. C. Métodos e técnicas de pesquisa social. 6a. ed. São Paulo: Atlas, 2010.

GOMES, A. D. A. O Portal dos Psicólogos, 2009. Disponivel em: $<$ http://www.psicologia.pt/artigos/textos/A0472.pdf>. Acesso em: 29 nov. 2016.

GOMÉZ, G. R.; FLORES, J. G.; JIMÉNEZ, E. G. Metodología de la investigación cualitativa. Málaga: Aljib, 1996.

GORETTI, A. C. S. A relação mãe-bebê na estimulação precoce um olhar psicanalítico. Dissertação de Mestrado. Brasília: Universidade Católica de Brasília, 2012.

GUIMARÃES, B. F. Escria e autoria: sobre o sujeiro que escreve. Dissertação de Mestrado. Florianópolis: Universidade Federal de Santa Catarina, 2007.

GUIMARÃES, R. Dicionário da Mitologia Grega. São Paulo: Cultrix, 1995.

HENWOOD, K. L. Qualitative inquiry: perspectives, methods and psychology. Grounded theory in psychological research. In: RICHARDSON, J.T.E. Handbook of qualitative research methods for psychology and the social sciences. Leicester, UK: BPS Books, 1996. 25-42 p.

JORGE, M. A. C.; FERREIRA, N. P. Freud, criador da psicanálise. 3. ed. Rio de Janeiro: Zahar, 2010.

KATZ, C. S. Complexo de Édipo. Rio de Janeiro: Civilização Brasileira, 2009.

KAUFMAN, P. Dicionário Enciclopédico da Psicanálise. O legado de Freud e Lacan. Rio de Janeiro: Zahar, 1996.

KENSKY, V. M. Memória e Ensino - Caderno de pesquisa. São Paulo: [s.n.], 1994.

KUPFER, M. C. M. Educação para o Futuro: Psicanálise e educação. 3. ed. São Paulo: Escuta, 2007.

LACAN, J. O seminário, livro 5: As formações do inconsciente. Rio de Janeiro: Zahar, [1958]1999.

LACAN, J. Os complexos familiares na formação do individuo. Rio de Janeiro: Zahar, 1985. 
LACAN, J. A juventude de Gide ou a letra e o desejo. In: Escritos. Rio de Janeiro: Zahar, 1998.

LACAN, J. O Seminário, Livro XX. Rio de Janeiro: Zahar, 2002.

LAJONQUIÈRE, L. D. A criança, "sua" (in)disciplina e a psicanálise. In: AQUINO, J. G. Indisciplina na escola alternativas teóricas e práticas. São Paulo: Summus, 1996.

LAJONQUIÈRE, L. D. Infância e ilusão (Psico)Pedagógica. Escritos de psicanálise e educação. Petrópolis: Vozes, 1999.

LAJONQUIÈRE, L. D. Figuras do Infantil: a Psicanálise na vida cotidiana com as crianças. Petrópolis: Vozes, 2010.

LAPlANCHE, J.; PONTALES, J. Vocabulário da Psicanálise. São Paulo: Martins Fontes, 2001.

MANNONI, M. A. A primeira entrevista em Psicanálise. Paris: Elsevier, 2004.

MARRA, M. M.; COSTA, L. F. A pesquisa-ação e o sociodrama: uma conexão possível? Revista Brasileira de Psicodrama, v. 12, n. 1, p. 99-116, 2004.

MARRA, M. M.; FLEURY, H. J. Sociodrama, um método, diferentes procedimentos. São Paulo: Ágora, 2010.

MARTINS, J.; BICUDO, M. A. A pesquisa qualitativa em Psicologia: fundamentos e recursos básicos. São Paulo: Moraes, 1989.

MEZAN, R. Pesquisa Teórica em Psicanálise. Psicanálise e Universidade, São Paulo, n. 2, p. 51-76, 1994.

MILLOT. [S.1.]: [s.n.].

MILLOT, C. Freud Antipedagogo. 1. ed. Rio de Janeiro: Zahar, 2001.

MINAYO, M. C. D. S. Ciência, técnica e arte o desafio da pesquisa social. In: MINAYO, M. C. D. S. Pesquisa Social teoria, método e criatividade. Petrópolis: Vozes, 2003. p. 9-29.

MONTEIRO, A. M.; MERENGUÉ, D.; BRITO, V. Pesquisa quantitativa e psicodrama. São Paulo: Ágora, 2006.

MORENO, J. Fundamentos do Psicodrama. II. ed. São Paulo: Summus, 1983.

MORENO, J. Psicodrama. São Paulo: Cultrix, 2008.

MORENO, J. L. Quem sobreviverá? Fundamentos da sociometria, da psicoterapia de grupo e sociodrama. Goiânia: Dimensão, 1992. 
MORENO, J. L. O que é Psicodrama?. Federação Brasileira de Psicodrama - FEBRAP, 2001. Disponivel em: <http://www.febrap.org.br/psicodrama/Default.aspx?idm=20>. Acesso em: 29 nov. 2016.

MORENO, Z. T. Psicomúsica e sociodrama. Buenos Aires: Paidós, 1965.

MOROZ, M.; GIANFALDONI, M. H. T. A. processo de pesquisa: Iniciação. 2. ed. Brasília: Líber, v. 2, 2006.

MULLAHY, P. Édipo mito e complexo. Rio de Janeiro: Zahar, 1965.

NASIO, J. D. Introdução às obras de Freud. Rio de Janeiro: Zahar, 1995.

NASIO, J. D. O prazer de ler Freud. Rio de Janeiro: Zahar, 1999.

NEME, L. Édipo e infância. In: Édipo, não tão complexo. Rio de Janeiro: Escola Letra Freudiana, 2008.

NÓVOA, A. O método (auto) biográfico na encruzilhada dos caminhos (e descaminhos) da formação dos adultos. Revista portuguesa de Educação, Lisboa, v. 1, n. 2, p. 7-20, 1988.

NÓVOA, A. Vida de professores. Porto: Porto, 1992.

NÓVOA, A. Formação de professores e trabalho pedagógico. Lisboa: Educa, 2002.

PAULO, T. S.; ALMEIDA, S. Memória educativa: um elo entre o passado e o presente do ser professor - In 6 Col. LEPSI IP/FE-USP 2006. proceedings.scielo, São Paulo, 2006. Disponivel em:

$<$ http://www.proceedings.scielo.br/scielo.php?pid=MSC0000000032006000100071\&script=s ci_arttext>. Acesso em: 29 nov. 2016.

PERCHBERTY, B. Entre o Tratamento e a Formação - Conflitos Identificatórios na Relação Pedagógica. In: ALMEIDA, S.; KUPFER, M. A Psicanálise e o Trabalho com a CriançaSujeito No Avesso do Especialista. Rio de Janeiro: Wak, 2011. p. 45-75.

PEREIRA, M. Menino-Menina. Estilos Clínicos, São Paulo, p. 268-278, Maio-Agosto 2013.

PINEAU, G.; GRAND, J. Les Histories de Vie. II. ed. Paris: Universtaies de France, 1996.

PLASTINO, C. A. O primado da afetividade. Rio de Janeiro: Relume Dumará, 2001.

PRAZERES, S. M. G. Constituição da Subjetividade Docente As Implicações na Prática Educativa - Dissertação de Mestrado. Brasília: UnB, 2007.

QUINET, A. Os outros em Lacan. Rio de Janeiro: Jorge Zahar, 2012.

QUINODOZ, J. Ler Freud - Guia de Leitura da Obra de S. Freud. Porto Alegre: Art Med, 2007. 
RUDGE, A. M. O infantil na Metapsicologia. Pulsional Revista de Psicanálise N. 126, São Paulo, p. 13-29, 1999.

SAFRA, G. Como a fenomenologia dialoga com a psicanalise - DVD, 2001-2006.

SANTOS, M. P. História da supervisão educacional no Brasil reflexões sobre política, pedagogia e docência. Rio de Janeiro: Wak, 2012.

SAURET, M. J. O infantil e a estrutura. São Paulo: Escola Brasilieira de Psicanálise, 1998.

SIBONY, D. Le Geste d'apprendre. In: Du Vécuetd'nvivable. Psychopathologie du Quotidien. Paris: Albin Michel, 1991.

SILVA, H. S. P. V. D. D. Sociodrama: um espaço de refúgio, liberdade e criatividade! Contributos da metodologia sociodramática na formação de educadores sociais. Revista Brasileira de Psicodrama, v. 16, n. 2, p. 87-100, 2008.

SOUSA, E. L. A. O inconsciente e as condições de uma autoria. In: Psicologia. São Paulo: USP, v. 10, 1999. 225-238 p.

TANIS, B. Memória e temporalidade. São Paulo: Casa do Psicólogo, 1995.

TRIVIÑOS, A. S. Introdução à pesquisa em ciências sociais: a pesquisa qualitativa em educação. São Paulo: Atlas, 1992.

TURATO, E. R. A questão da complementaridade e das diferenças entre métodos quantitativos e qualitativos de pesquisa uma discussão epistemológica necessária. In: NOBREGA, J.; GRUBITS, S. Método Qualitativo Epistemologia, Complementaridades e Campos de Atuação. São Paulo: Vetor, 2004. p. 17-52.

VOLTOLINI, R. As vicissitudes da transmissão da Psicanálise a educadores In: An. 3 Col. LEPSI IP/FE-USP 2002. Proceedings online, 2001. Disponivel em: $<$ http://www.proceedings.scielo.br/scielo.php?pid=MSC0000000032001000300036\&script $=\mathrm{s}$ ci_arttext>. Acesso em: 29 nov. 2016.

VOLTOLINI, R. An. 3 Col. LEPSI IP/FE-USP. proceedings.scielo, 2002. Disponivel em: $<$ http://www.proceedings.scielo.br/scielo.php?pid=MSC0000000032001000300036\&script $=\mathrm{s}$ ci_arttext>. Acesso em: 29 nov. 2016.

VOLTOLINI, R. Educação e psicanálise. $1^{\circ}$ reimpressão. ed. Rio de Janeiro: Zahar, 2011.

ZAVARONI, D. D. M. L.; VIANA, T. D. C.; CELES, L. A. M. A Constituição do Infantil na Obra de Freud. http://www.scielo.br/pdf/epsic/v12n1/a08v12n1.pdf, 2007. Disponivel em: $<$ http://www.scielo.br/pdf/epsic/v12n1/a08v12n1.pdf $>$. Acesso em: 2015. 


\begin{abstract}
APÊNDICES
Apêndice A - Termo de consentimento livre e esclarecido das professoras
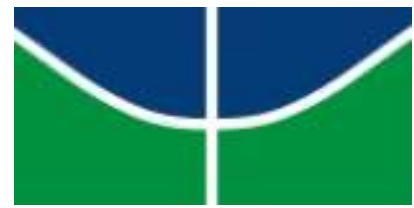

UNIVERSIDADE DE BRASÍLIA FACULDADE DE EDUCAÇÃO

PROGRAMA DE PÓS-GRADUAÇÃO EM EDUCAÇÃO
\end{abstract}

TERMO DE CONSENTIMENTO LIVRE E ESCLARECIDO

$\mathrm{Eu}$,

portador da identidade: , abaixo qualificado, DECLARO

para fins de participação em pesquisa, na condição de sujeito da pesquisa, que fui devidamente esclarecido a respeito do projeto de pesquisa, versando sobre o infantil na constituição da subjetividade: o memorial educativo de professores em escrita e ação, coordenado pela Prof . $^{\mathrm{a}}$ $\operatorname{Dr}^{\mathrm{a}}$. Inês Maria Marques Zanforlin Pires de Almeida, do curso de Mestrado em Educação da Universidade de Brasília, quanto aos seguintes aspectos:

- Justificativa, objetivos e procedimentos que serão utilizados na pesquisa;

- Garantia do esclarecimento antes e durante o curso da pesquisa, sobre a metodologia utilizada;

- Liberdade de se recusar a participar ou retirar seu consentimento, em qualquer fase da pesquisa, sem penalização alguma e sem prejuízo do seu cuidado.

- Garantia de sigilo quanto aos dados confidenciais envolvidos na pesquisa, assegurandose absoluta privacidade. 
DECLARO, outrossim, que após convenientemente esclarecido pela pesquisadora e ter entendido o que me foi explicado, consinto voluntariamente participar desta pesquisa.

Brasília, de de 2016.

\section{QUALIFICAÇÃO DO DECLARANTE}

TERMO DE CONSENTIMENTO LIVRE E ESCLARECIDO

Sujeito objeto da pesquisa:

Identidade data de nascimento $\operatorname{Sexo}() \mathrm{M}() \mathrm{F}$

Endereço:

Bairro: Cidade:

CEP: Telefone:

Assinatura do declarante

\section{DECLARAÇÃO DO PESQUISADOR}

Declaro para os fins de realização de pesquisa, ter elaborado esse Termo de Consentimento Livre e Esclarecido (TCLE), cumprindo todas as exigências contidas nas alíneas acima elencadas e que obtive, de forma apropriada e voluntária, o consentimento livre e esclarecido do declarante acima qualificado para a realização dessa pesquisa.

Brasília, de de 2016 
Katilen Machado Vicente Squarisi 
Apêndice B - Termo de consentimento livre e esclarecido da diretora
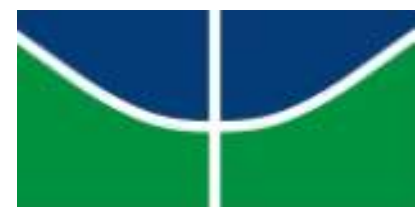

UNIVERSIDADE DE BRASÍLIA FACULDADE DE EDUCAÇÃO PROGRAMA DE PÓSGRADUAÇÂO EM EDUCAÇÃO

$$
\text { Brasília-DF， de de } 2016 .
$$

\section{TERMO DE CONSENTIMENTO LIVRE E ESCLARECIDO}

Título da pesquisa: $\mathrm{O}$ infantil na constituição da subjetividade: o memorial educativo de professores em escrita e ação.

Pesquisadora responsável: Katilen Machado Vicente Squarisi- FE/UnB

Orientadora: professora Dra. Inês Maria Zanforlin Pires de Almeida - FE/UnB

Garantia de acesso: em qualquer etapa do estudo você terá acesso à pesquisadora responsável pela pesquisa - katilensquarisi@gmail.com

Objetivo do estudo: compreender a dimensão do infantil na constituição da subjetividade de professores à luz da teoria psicanalítica.

Prezada Diretora,

Solicito autorização para desenvolver a pesquisa descrita em anexo, para a qual será necessária a participação voluntária de um grupo de docentes. Esta participação consistirá em realização de entrevista, memória educativa, participação em sociopsicodrama e momentos formativos a serem realizados em horários de coordenação pedagógica. Comprometo-me a darlhe todas as informações sobre a referida pesquisa antes, durante e após a coleta dos dados da pesquisa.

Benefício da pesquisa: contribuir para o desenvolvimento profissional do corpo docente participante. Custo/Reembolso: Não haverá ônus com a participação. A participação será 
totalmente espontânea e gratuita não havendo nenhuma cobrança com o que será realizado. A instituição não receberá nenhum pagamento com a sua participação.

Sigilo: as informações fornecidas serão usadas somente para efeito desta pesquisa, sem identificação dos interlocutores, isto é, os nomes não serão mencionados em nenhum momento, mesmo quando os resultados forem divulgados em qualquer forma. A sua assinatura indica sua concordância em fornecer as informações solicitadas.

\author{
Nome completo
}

Carimbo/Assinatura

Katilen Machado Vicente Squarisi: katilensquarisi@gmail.com 
Apêndice C - Memória educativa
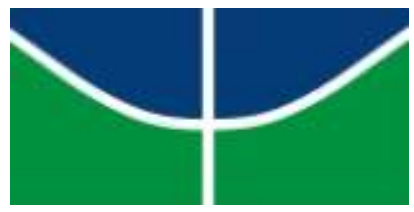

UNIVERSIDADE DE BRASÍLIA FACULDADE DE EDUCAÇÃO

PROGRAMA DE PÓS-GRADUAÇÃO EM EDUCAÇÃO

Instrumento: Elaboração da Memória Educativa

Prezado(a) professor(a),

Propomos como elaboração de sua memória educativa uma imersão em sua trajetória de vida como estudante, resgatando na sua história, tempos, episódios, situações, pessoas, imagens, processos dessa experiência, quer sejam de aspectos positivos ou não.

Faça um reolhar a essa trajetória e reorganize criticamente suas representações e sentimentos que marcaram sua caminhada como aluno e que se inscrevem hoje na sua prática docente.

Percurso possível:

- Inicialmente percorra suas sensações, quer sejam visuais, olfativas, auditivas, táteis, afetivas e tantas outras que constituem suas experiências infantis. Registre tudo.

- Retome seu processo de escolarização, pontuando:

- o(a) professor(a) de que mais, ou menos, gostou;

- as disciplinas com as quais mais se identificou e aquelas em que teve grandes dificuldades (quanto à aprendizagem);

- os conteúdos aprendidos prazerosamente ou dolorosamente;

- as atividades realizáveis com gosto e sucesso e outras de forma indesejável ou com insucesso; 
- como os conteúdos foram ensinados/ aprendidos e metodologias que deixaram marcas positivas e negativas;

- as relações professor-aluno (comunicações, estilos, posturas dos/as professores/as)

- o processo avaliativo (modalidades/frequência);

- o ambiente escolar (aspectos físicos, lugares, infraestrutura pedagógica, aspectos relacionais/ intrapessoais);

- a relação família/escola/sociedade;

- como você se sentia como aluno(a).

- Presentifique sua análise, observando:

- como me percebo diante dessa constituição ao longo de tantos anos e com diferentes modos de ensinar;

- dificuldades existentes entre o que e o como me foi ensinado e os meus procedimentos e posturas atuais em sala de aula.

- razões que determinaram minha escolha profissional a partir dessa vivência e do meu processo de formação;

- como ressignifico, hoje, os papéis do(a) professor(a) e do(a) aluno(a) a partir das minhas experiências escolares anteriores?

Escreva sem limites de espaço para o seu registro. Pode-se incluir imagens (desenhos, filmes e fotos) de sua trajetória que o auxiliem a revivê-la. Uma boa viagem através dos caminhos mnemônicos da sua historicidade.

Para facilitar sua escrita, apresentamos um diagrama que poderá ajudá-lo(a) a situar-se no curso de sua trajetória de aluno a professor, ao longo do ciclo vital. 
Trata-se de uma espiral das interações com o mundo escolar no qual se desenvolveu o processo formal de ensino-aprendizagem. Essa espiral reflete uma dinâmica sequencial integrativa: os processos de ensino-aprendizagem ocorrentes em cada faze são incorporados às vivências dos estágios seguintes, num nível crescente de complexidade. 
Apêndice D - Folder do curso

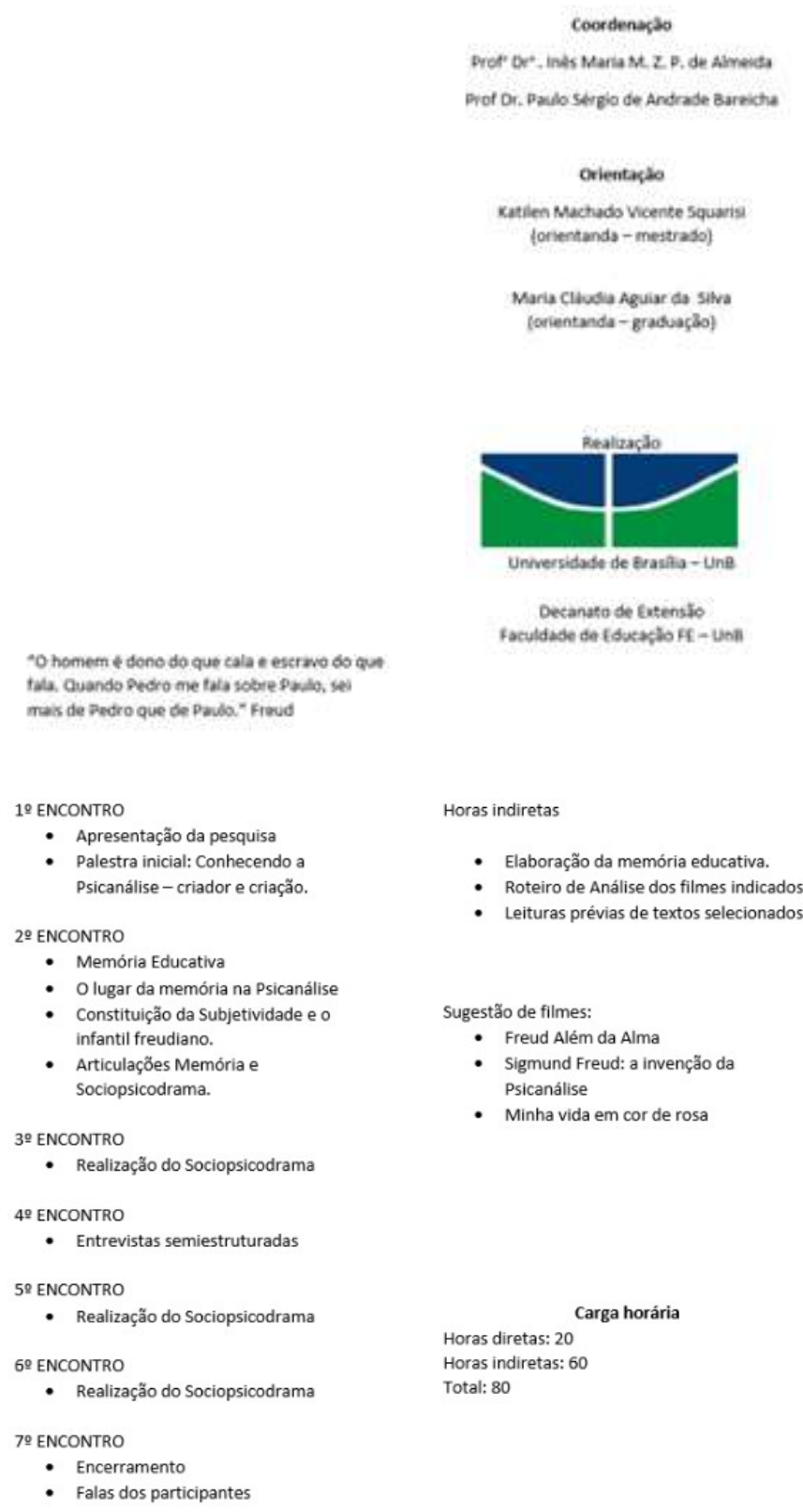


Apêndice E - Entrevista semiestruturada

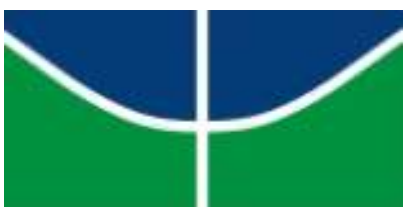

UNIVERSIDADE DE BRASÍLIA

\section{FACULDADE DE EDUCAÇÃO}

Prezado (a) professor (a),

O objetivo desta entrevista é levantar dados de sua vida pessoal e profissional para analisar a influência destes sobre a sua prática pedagógica e constituição subjetiva.

Com o seu consentimento, esta entrevista será gravada em áudio e posteriormente será transcrita para análise dos dados. O conteúdo da mesma será utilizado na dissertação, mas sua identidade será mantida em sigilo.

\section{ROTEIRO}

- As entrevistas foram norteadas pelos seguintes temas:

○ A posição do sujeito/professor e sua compreensão desde os primeiros tempos do aprendizado na educação infantil em sua história de vida.

○ Percepção de si diante do aluno que foi: possibilidades de reconhecimento ou estranhamento.

○ As relações feitas entre a apropriação de um saber referente ao campo profissional e as possibilidades da repercussão no cenário da sala de aula.

○ Enlaces entre as facilidades e as dificuldades na constituição da subjetividade e a relação do sujeito professor/aluno frente ao infantil.

○ Repercussão da formação e constituição da subjetividade docente e sua prática pedagógica.

- Traços de identificação e lembranças que marcam a trajetória do sujeito/professor e como o infantil se insere. 
Apêndice F - Ficha de avaliação do curso

Ficha de avaliação do curso

Prezada Cursista,

Sua colaboração no preenchimento da avaliação é muito importante.

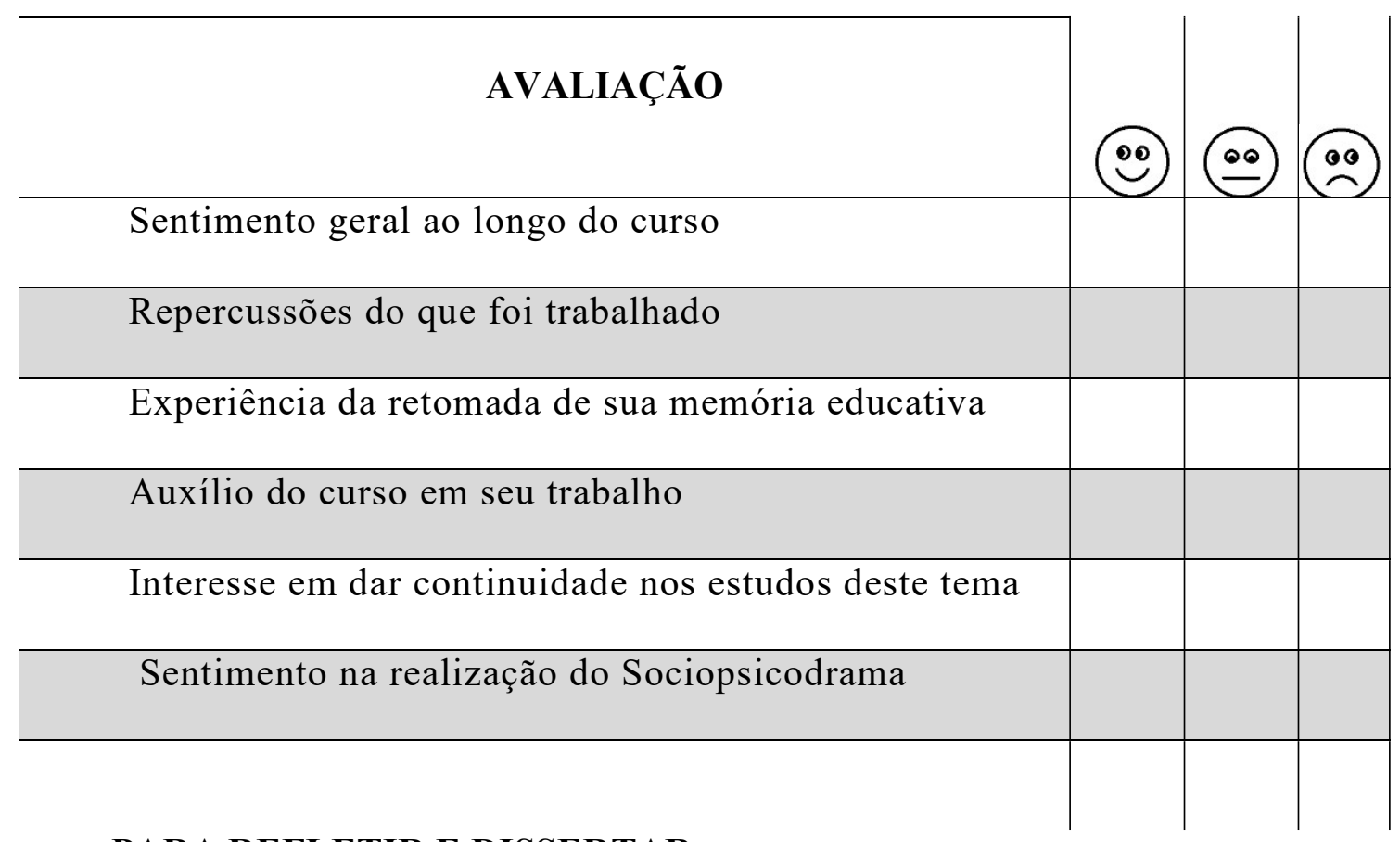

PARA REFLETIR E DISSERTAR:

O que o curso suscitou em você? Percebeu efeitos no seu trabalho? 
Apêndice $\mathrm{G}$ - Relatório dos encontros (diário de campo)

\section{RELATÓRIO DOS ENCONTROS}

\section{Diário de Campo: Encontros}

Inicialmente fomos apenas pela manhã num momento chamado coordenação coletiva. Combinamos com a direção da escola que os encontros aconteceriam às quartas-feiras, pelas manhãs e tardes.

Passamos a manhã conhecendo as questões da escola e de algumas professoras. Nessa coordenação, quinzenalmente às quartas-feiras, há um momento com uma psicanalista e psicopedagoga que dura uma hora, e que a diretora achou por bem marcar nossos encontros no mesmo dia pela proximidade com os temas trabalhados e pela coincidência com nosso tema. De certa forma preparou o grupo de professores para as atividades que desenvolvemos em seguida sobre psicanálise e memória educativa.

\section{$1^{\circ}$ Encontro}

\section{Matutino:}

Neste encontro levamos a proposta do projeto de pesquisa à escola a fim de esclarecer o trabalho que desenvolveríamos com as professoras como segue o folder:

Havia dez professoras na coletiva desta manhã. Fizemos a apresentação do curso: O lugar do infantil na memória educativa: implicação e reflexão em escrita e ação.

Primeiramente expliquei como seria o curso e o foco do nosso trabalho na pesquisa de mestrado, constituição da subjetividade com enfoque no infantil numa abordagem psicanalítica e sociopsicodramática. Logo após, também apresentou o projeto do PIBIC- Programa Institucional de Bolsas de Iniciação Científica intitulado: a importância da dimensão do amor, da presença e da palavra na transmissão de ensinamentos, desenvolvido por uma graduanda em Pedagogia ambas sob a mesma orientação que responde às demandas institucionais/ acadêmicas sobre articulação pós-graduação e graduação.

Em seguida apresentamos um vídeo em que Sigmund Freud se apresenta como o "pai da Psicanálise", numa breve autobiografia a fim de situar as cursistas sobre as origens históricas do aporte teórico de nossas pesquisas.

Seguindo a sequência de apresentação do curso, trabalhamos com o grupo das professoras da manhã: memória educativa; o lugar da memória na Psicanálise; constituição da Subjetividade e o infantil freudiano; articulações memória e Sociopsicodrama. 
Pela manhã existiu um grande interesse no tema e todas as professoras se inscreveram no curso. Ocorreram relatos de professoras que cursaram também Pedagogia na UnB. Algumas lembraram que seu primeiro contato com a Psicanálise foi em aulas de Inconsciente e Educação ministradas pela professora orientadora, outra ainda lembrou de sua maneira humana e acessível quando na direção da Faculdade de Educação (FE).

A coordenação coletiva da tarde contou com professoras que ministram aulas há anos, e tem mais experiência. A estas professoras a proposta do curso pareceu ser uma novidade maior, mais proveitosa, como uma espécie de reconfigurar a postura em sala de aula. O curso teve uma ótima aceitação, o material que levamos foi explorado por elas com perguntas e observações.

\section{$2^{\circ}$ Encontro}

\section{Matutino:}

Neste dia o encontro na coordenação coletiva foi com a presença da professora orientadora. No início após apresentar-se, resgatou a história do trabalho inicial com a professora Alexandra Militão, de quando fazia o doutorado estudando a Psicanálise e a sedução que teve com o tema.

Distribuímos um trecho do livro de Sigmund Freud, sobre A etiologia da histeria “Arqueólogo do inconsciente" como reflexão inspiradora para atividade que deveriam elaborar (memória) e fizemos a leitura do mesmo.

Imaginemos que um explorador chega a uma região pouco conhecida onde o seu interesse é despertado por uma extensa área de ruínas, com restos de paredes, fragmentos de colunas e lápides com inscrições meio apagadas e ilegíveis. Pode contentar-se em inspecionar o que está visível, em interrogar os habitantes que moram nas imediações - talvez uma população semibárbara - sobre o que a tradição lhes diz a respeito da história e do significado desses resíduos arqueológicos, e em anotar o que eles lhe comunicarem - e então seguir viagem. Mas pode agir de modo diferente. Pode ter levado consigo picaretas, pás e enxadas, e colocar os habitantes para trabalhar com esses instrumentos. Junto com eles, pode partir para as ruínas, remover o lixo e, começando dos resíduos visíveis, descobrir o que está enterrado. Se seu trabalho for coroado de êxito, as descobertas se explicaram por si mesmas: as paredes tombadas são parte das muralhas de um palácio ou de um depósito de tesouro; os fragmentos de colunas podem reconstituir um templo; as numerosas inscrições, que, por um lance de sorte, talvez sejam bilingues revelam um alfabeto e uma linguagem que, uma vez decifrados e traduzidos, fornecem informações nem mesmo sonhadas sobre os eventos do mais remoto 
passado em cuja homenagem os monumentos foram erigidos. Saxa loquuntur! (as pedras falam!) - do Latim.

Freud, S. (1896). A etiologia da histeria. Em: Edição Standard Brasileira Obras Psicológicas de Sigmund Freud. Rio de Janeiro: imago, vol. III, 1996.

Como horas indiretas do curso solicitamos a elaboração da memória educativa. Esclarecendo-os que a escrita da memória educativa é compreendida como um dispositivo no qual o sujeito do inconsciente comparece. Foi entregue o espiral como norteador na escrita da memória.

\section{Vespertino:}

Assim como apresentamos na coletiva da manhã, esclarecemos sobre a escrita da memória educativa e entregamos também o espiral com as etapas do processo escolar como orientador para reflexões/elaboração.

O debate e troca de ideias entre as professoras foi muito rico no sentido de se perceber falas e vivências relacionadas com o aporte psicanalítico por experiências individuais e em grupo. Foram esclarecidas várias dúvidas.

Algumas professoras permitiram-se contar memórias de fatos e/ou acontecimentos naquele momento, como esse relato do trabalho perfumado que uma professora contou vivenciado na $5^{\mathrm{a}}$ série quando com maior capricho como todos que fazia e sem querer uma página sujou de óleo e ficou super preocupada pois até fazer novamente como era à mão seria trabalhoso. Então a mãe deu a ideia de jogar talco para amenizar a mancha de óleo e ela resolveu tentar e colocou bastante talco (que segundo ela era cheiroso) e no dia seguinte entregou o trabalho. Percebeu que esse professor começou a dar algumas indiretas para ela e se insinuava como se ela estivesse gostando dele e ela não entendia. Até que chegou o dia da entrega do trabalho e ao entregar o dela o professor comentou que aquele trabalho estava muito perfumado e caprichado! Deixou claro a turma que ela estava apaixonada por ele e o trabalho foi a demonstração. Ela se sentiu constrangida e com muita vergonha. Teve que lidar com essa situação durante dois anos já que o professor continuou com a turma no ano seguinte.

O Memorial Educativo é escrito pelas lembranças do passado através das marcas deixadas no sujeito, os períodos seguem uma sequência sistemática e se facilita pela utilização do recurso do espiral.

A seguir o espiral: 


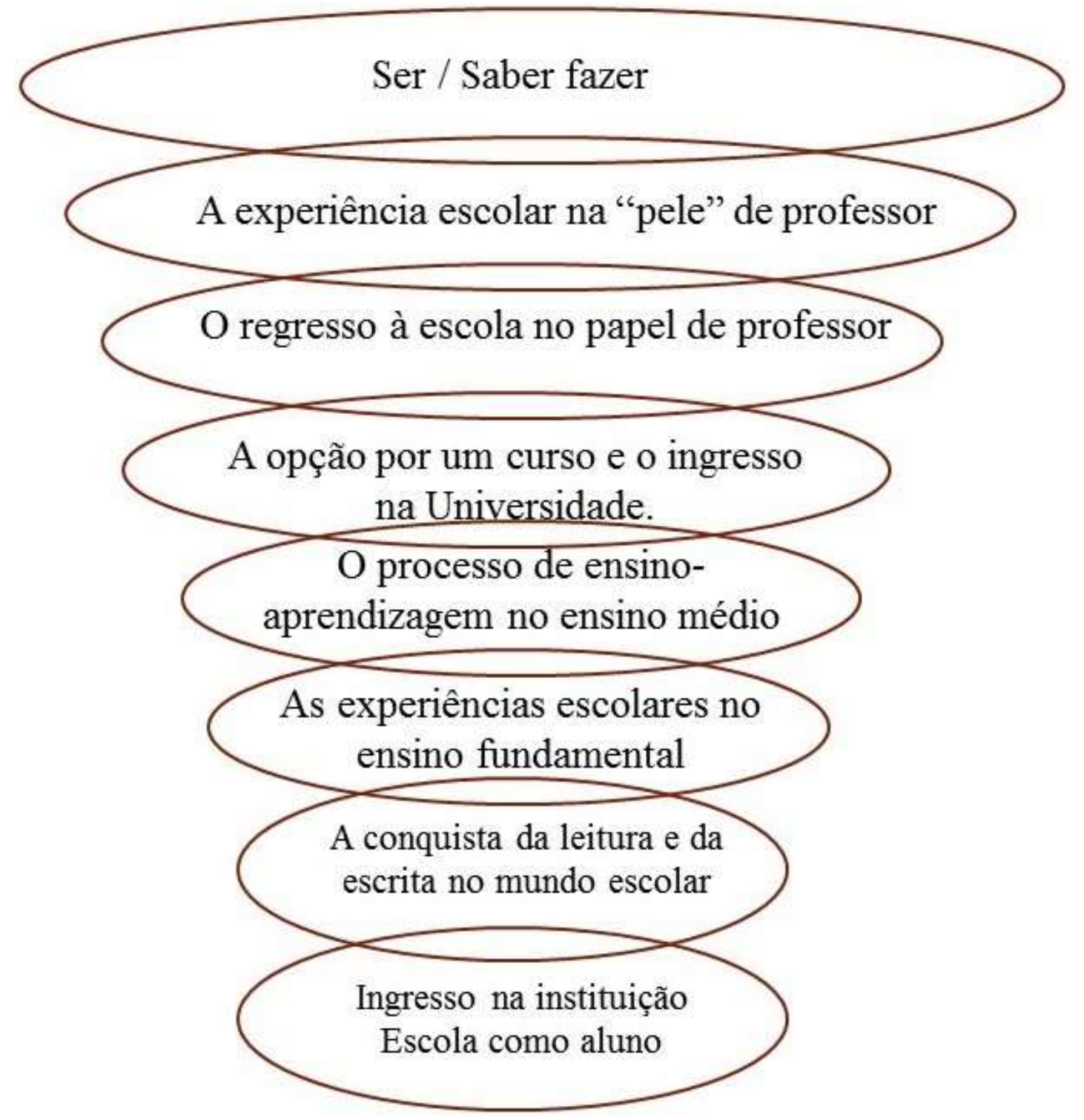

Figura 2 - Espiral da memória educativa

\section{$3^{\circ}$ Encontro}

\section{Matutino:}

Este foi o primeiro dia do Sociopsicodrama com apresentação do professor Paulo Bareicha, psicólogo, educador e psicodramatista.

Descrição da cena: a atividade iniciou com o grupo formando um círculo, de forma que as participantes ficavam lado a lado, ombro a ombro. A pedido do professor deveriam lembrarse de uma música da sua pré-escola, surgindo muitas dentre as quais: Escravos de Jó, Mãezinha do céu, Ciranda cirandinha, Pai Francisco cantadas em coro.

Usando a estratégia de aquecer a mão direita no peito num movimento de fricção buscando o que "haveria de bom no coração" e oferecendo está mão a pessoa ao lado, todas 
deram as mãos. Num exercício de trabalho de confiança do grupo, no grupo começando em dupla, foram dando as mãos se esticando e equilibrando-se. A cada entrada de um novo membro o grupo ficava mais forte. Isto para explicitar que o grupo deve acolher os medos e as fraquezas de qualquer natureza daqueles que o compõe. Como quando uma professora diz antes de entrar na roda "estou com medo" e a outra retruca "se tivesse medo não dava aula" acolhendo a colega na roda.

Neste clima o professor Paulo solicita o relato de uma memória escolar que tenha acontecido até a $4^{\mathrm{a}}$ série (atual $5^{\mathrm{a}}$ ano), fosse uma memória boa ou não, mas que elas se lembrassem bem. O primeiro relato foi de uma memória que ocorreu quando uma professora tinha 6 anos. Um aluno da sua sala que, disse querer muito namorar, um dia a chamou quando estava dormindo, já que a escola era integral e após o almoço deitavam para dormir, mas ela não o respondeu. A reação do garoto foi de mordê-la na boca. Sangrando foi embora do colégio levada pela prima da mãe, que era sua professora. Ela se refere a essa memória como uma lembrança muito ruim e é a que primeiro vem à mente ao pensar em memória educativa. A memória seguinte foi relatada pela bibliotecária da escola. Um dia ao arrumar os livros da biblioteca viu o livro Pollyanna moça e recordou que na sua $3^{\mathrm{a}}$ e $4^{\mathrm{a}}$ série ela e a turma aguardavam ansiosamente a leitura deste livro. Logo em seguida é a coordenadora pedagógica da escola quem relata sua memória pedagógica que marca dois momentos diferentes de sua vida escolar. Quando alfabetizada usou a cartilha Caminho Suave. Após a professora chegar de viagem da cidade vizinha trazendo essas cartilhas para a turma, fez um evento em sala para entregá-las a cada aluno. A partir da encenação com fantoche da história da formiguinha as cartilhas foram entregues. Esta memória marcou muito a professora que relata a busca por esta história da formiguinha. Já na UnB na aula do um certo professor, ele conta essa história que a coordenadora tanto buscou.

Em meio aos relatos das memórias educativas, uma fala chamou atenção: "Engraçado que essa história de escola, me lembra pessoas [...] a memória que eu tenho dessa escola é uma memória afetiva gigantesca! ", ressaltando que as memórias educativas remetem muito mais à pessoas e sentimentos do que ao conteúdo ministrado em sala de aula. Outro depoimento em que uma outra professora diz: "Eu lembro das minhas professoras com muito carinho" reforça ainda mais a ideia anterior.

Após os relatos das memórias, o professor Paulo pede que voltem a mão direita ao "coração" para buscar qual afeto, sentimento que essa memória evocada traz e nomear o afeto que traduz aquela memória, como um título. Os títulos foram: desconfiança, saudade, 
felicidade, nostalgia, sinceridade, indignação, incompletude, segurança, tristeza, prazer e madrinhagem (até palavras foram criadas). Ao falar o título do seu afeto, elas iam se distribuindo no espaço da roda formada por todas de pé. Em seguida sem sair do lugar, “tocavam os afetos" mais próximos. O professor Paulo comenta que: “essas são as nossas conexões inconscientes, eu diria mais, até estão descobrindo isso, até neurais elas estão com esse tipo de relação". Em seguida sugere que façam uma pose, imitando estátuas, em relação aos sentimentos que se conectaram. Voltando a posição inicial de roda formada: ombro a ombro, pede que falem uma palavra sobre a vivência do dia, atendendo à solicitação surgem as palavras: fé, satisfação, diferente, prazer, saudade, amor, resiliência, compreensão, delicadeza, liberdade.

\section{Vespertino:}

O professor Paulo se apresenta e pede a apresentação das professoras e a formação que tiveram.

O momento se inicia com formação da roda, com as professoras encostando ombro a ombro. A pedido do professor elas sugerem o movimento: flexionando joelhos e depois fazem um balanço pendular com o corpo. Elas buscam lembrar nomes de professoras de $1^{\mathrm{a}}$ a $4^{\mathrm{a}}$ série que tiveram. Em seguida resgatam músicas. A primeira é cantada em coro: "Mãezinha do céu eu não sei rezar...Mãezinha eu quero te ver lá no céu”. O professor pede outra música e a próxima é: "Rala o cocô, mexe a canjica" - algumas cantam. Com dificuldade tentam lembrar da música Festa do Interior "Segura as pontas, meu coração. Bombas [...] Ninguém matava, ninguém morria. Nas trincheiras da alegria. O que explodia era o amor. Outra música lembrada e cantada em coro foi: "O meu chapéu tem três pontas, tem três pontas o meu chapéu, se não tivesse três pontas não seria o meu chapéu..."

O professor Paulo questiona:

- A música que vocês propuseram é de que ano?

Em resposta falam 1990, 1978, 1972, 1970...

O professor pergunta quem usou cartilha. E elas lembram da cartilha "Caminho Suave" - respondem em coro. Porém outras duas respondem que já usaram livro.

O professor Paulo pede que levem a mão no peito e pensem, que sentimento elas lembram dessa época. Uma responde "Saudade, da escola e dos meus colegas". O professor orienta que a mão que está no coração você oferece a uma colega.

Em duplas e de mãos dadas um sugere o movimento ao outro e o outro segue este movimento, depois inverte-se. Agora uma de frente para outra testam equilíbrio, depois em trio, 
em grupo de quatro e assim por diante, até as sete professoras estarem na roda equilibrando-se e esticando-se. Uma professora que está gestante sente confiança no professor Paulo e em outra professora alta. O professor fala sobre fortalecer o grupo protegendo, fortalecendo o mais fraco, não importando a natureza desta fraqueza, porque o grupo ganha força se estiver junto.

O professor Paulo começa contando uma memória dele que se referia ao caminho que fazia para ir à escola. Depois uma professora decide compartilhar uma memória dela. Apesar de não lembrar do nome da professora que ela teve, lembra que ela jogava nos alunos giz e às vezes até o apagador. Ela expressa ao se lembrar da memória: "Ela - a professora - era louca, mas não lembro o nome dela". Outra professora retoma dizendo que antes ela não sabia ler e que na sala que estudava uma mesma professora dava aula para três séries diferentes, todas na mesma sala. Sua professora dividia o quadro em três partes e assim separava o conteúdo de cada série dada no dia. E nesta memória lembra que copiava do quadro todas as partes. O que ficou marcado para ela, é que a escola do Goiás, onde essa cena ocorreu deixava a desejar porquê ela passou sem saber ler. E lembra que quando estudava lá haviam apenas duas salas, mas que numa visita recente à escola surpreendeu se o quanto agora está imensa.

Em seguida outra professora diz: "lembrei de uma professora aqui agora. Ela era pequeninha e tinha um cabelo armado, um dia ela foi de bobs" - risos. E continuou: "o filho dela morreu de leucemia no ano que a gente teve aula com ela, ele tinha uns 9 anos. Eu ainda tenho contato com os colegas dessa escola. Mas também lembro da escola de freira..."

Outra professora prossegue contando que se lembra de ter sentado no que ela se referia como "morrinho de formigas". E depois de sentir várias picadas, levantou-se do morrinho chorando. Ela conta: "passaram álcool em mim e eu esperei minha mãe chegar”. O quinto relato é de uma memória que aconteceu no Rio de Janeiro quando a professora tinha 5, 6 anos: “e 'venderam' na escola que seria bom desfilar no 7 de setembro [...] Aí eu vi que a gente tinha que sair da escola. Mas eu disse: não vou sair da escola, e eu não fui. Minha mãe comentou que eu não fui por semanas!

Outra professora lembra que pegou flores para a tia do escolar, e ao pegar pisou num prego que havia numa madeira. Por isso foi levada ao hospital e precisou faltar as aulas. Ela comenta: "me senti importante porquê eu faltei na escola. Naquela época não podia faltar". Por fim uma professora lembrou que havia competição de redação em sua escola. Ela participava e uma vez ganhou em primeiro lugar. Sua professora a chamou para receber o prêmio: uma bicicleta. Outra vez ganhou um relógio. E ela se lembra: "A professora nos motivava muito". O professor Paulo pergunta se alguém queria ver a sua história de outro ângulo, encenada. 
A professora que contou a história do formigueiro pediu que a dela fosse encenada. Desta vez ela conta com mais detalhes a história. Mesmo os detalhes que ela não tinha certeza, passaram a fazer parte da história. Ela começa dizendo: "Era uma sexta eu estava na casa da minha avó, que tinha a melhor mamadeira [...] Sentei no morrinho (formigueiro) que para mim era só um morrinho, as formigas subiram de uma vez”. E a história segue...

O professor Paulo pede que, para a encenação, a professora escolha dentre as suas colegas alguém para fazer o papel de sua avó. A professora desconfortável com a situação, num riso nervoso pergunta se alguém quer participar. O professor lembra do momento inicial que tiveram quando ele falou sobre acolher as fraquezas do grupo e se fortalecer. E pergunta à todas: “Alguém não gostaria de participar? ” Lembrando que fizeram o pacto de proteger o mais fraco no grupo. Porém rapidamente todas se manifestam desejosas para participar. A encenação acontece após a escolha de quem faria cada personagem da história. Esse relato foi representado através do sociopsicodrama onde várias professoras tiveram um papel. A própria professora como aluna vivenciando essa memória, a professora de classe que socorreu no momento do ocorrido, a servidora que passou o álcool, os coleguinhas de classe e a mãe. Foi muito interessante reviver a cena e a professora disse ter achando graça do momento.

\section{$4^{\circ}$ Encontro}

Neste encontro entrevistamos as professoras pela manhã e pela tarde.

\section{Relatos das entrevistas}

Realizamos entrevistas com quatro professoras que se ofereceram e mostraram disponibilidade.

O mais importante nas entrevistas foi perceber a profundidade dos conteúdos e discussões significativas, vivenciando o infantil na constituição da subjetividade e o contexto vivido em sala de aula. A fala das professoras entrevistadas foi representativa onde a proximidade ocorreu de forma que ficaram à vontade nos relatos.

\section{$5^{\circ}$ Encontro}

\section{Matutino:}

O professor Paulo retoma o trabalho perguntando sobre o tempo que teremos para a realização do Sociopsicodrama por conta do cuidado necessário com o mesmo. Ele explica que quando se faz algo na ordem do Psicodrama a pessoa vai entrando em um universo de memória, chamado de realidade suplementar, algo como o universo do sonho não podemos sair, despertar dessa realidade de uma vez. Por isso é preciso atentar-se ao tempo, que foi demarcado. 
O Sociopsicodrama então tem início com a leitura do texto Idade Escolar Normal do livro Volta ao Lar, tese de doutorado de um neopsicanalista. Neste dia como objetivo buscou focar no campo da infância, da pré-adolescência e adolescência.

Inicia a leitura das questões em voz alta para que o grupo o acompanhe, porém deveriam responder individualmente preenchendo o questionário que acompanhava o texto, buscando responder com sim ou não às questões, sem fazer uso do talvez.

19. Você costuma se comparar com outras pessoas e sempre se sente inferior?

20. Você gostaria de ter mais amigos de ambos os sexos?

21. Costuma sentir-se pouco à vontade em situações sociais?

22. Sente-se pouco à vontade como parte de um grupo? $4 \mathrm{~A}$. Sente-se melhor quando está sozinho?

23. Às vezes dizem que você é muito competitiva, sente que precisa ganhar?

24. Frequentemente tem conflitos com seus companheiros de trabalho? 6 A. E com as pessoas da família?

25. Em uma negociação você cede completamente? 7 A. Insiste em fazer as coisas do seu modo?

26. Orgulha-se de ser rígido e literal seguindo a lei ao pé da letra?

27. Você sempre procrastina as coisas?

28. Tem dificuldade em terminar as coisas?

29. Acha que devia fazer as coisas sem nenhuma instrução?

30. Tem muito medo de cometer erros? 12 A. Sente-se extremamente humilhada quando é obrigada a constatar os próprios erros?

31. Fica zangada com frequência e critica muito as outras pessoas?

32. É deficiente nas aptidões básicas da vida? 14 A. Ler, falar, ou escrever gramaticalmente ou fazer cálculos matemáticos básicos.

33. Passa muito tempo analisando obcecada por alguma coisa que disseram ao seu respeito?

34. Sente-se feia e inferior? 16 A. Se sim, tenta disfarçar isso com roupas, coisas, dinheiro, maquiagem?

35. Costuma mentir para você mesma e para os outros com frequência?

36. Acredita que por melhor que você faça, nunca está fazendo a coisa certa?

No texto o autor afirma que se uma das questões acima teve sim como resposta provavelmente o respondente teve sua criança ferida na idade escolar. E há vários graus de 
ferimento. Quanto mais perguntas obtiverem sim como resposta mais sua criança está ferida. Após a leitura dessa afirmação o grupo de professoras se mostra agitado.

O próximo passo foi compartilhar, por quem se sentiu à vontade, as suas respostas às questões apresentadas. O professor, como diretor de cena destaca que seu interesse é especialmente nas cenas lembradas, que tenham acontecido em ambiente escolar, e que compõem a visão que o sujeito tem de si. Ele lembra que todos têm na memória professores marcantes, fossem eles "bons" ou "ruins" e que talvez algumas das questões acima remetessem às memórias de certos momentos.

Em seguida foi feito a contagem das professoras que responderam "sim" a cada questão, para que depois fossem vistos os itens que a maior parte da turma tem em comum. Abaixo o quadro com o total de "sim" dado para cada questão:

\begin{tabular}{|c|c|c|c|c|c|c|c|c|c|c|c|c|}
\hline QUESTÃO & 1 & 2 & 3 & $4 \mathrm{~A}$ & AB & 5 & $6 \mathrm{~A}$ & $6 \mathrm{~B}$ & $7 \mathrm{~A}$ & $7 \mathrm{~B}$ & 8 & 9 \\
\hline SIM & 2 & 3 & 6 & 3 & 5 & 2 & 3 & 6 & 2 & 2 & 1 & 6 \\
\hline QUESTÃO & 10 & 11 & $12 \mathrm{~A}$ & $12 B$ & 13 & 14 & 15 & $16 \mathrm{~A}$ & $16 \mathrm{~B}$ & 17 & 18 & - \\
\hline SIM & 5 & 1 & 6 & 2 & 1 & 0 & 5 & 1 & 1 & 1 & 2 & . \\
\hline
\end{tabular}

Quadro 6 - Questões do texto idade escolar normal

Fonte autora

Neste encontro havia 15 professoras presentes. Nenhuma professora respondeu "sim" à questão 14, apontando que o grupo se percebe eficiente nas aptidões básicas da vida. As questões 3, 6A, 9 e 12 receberam o maior número de "sim". Relembrando e analisando as questões citadas acima:

A questão 3 é a primeira que recebe o maior número de "sim" dentre as outras questões. A pergunta é: Costuma sentir-se pouco à vontade em situações sociais? Ainda que as questões tenham sido respondidas por professoras ativas que em seu cotidiano trabalham em grupo, seja liderando um, quando ministra aulas por exemplo, seja fazendo parte, quando está num grupo de professoras de uma escola. Há ainda um desconforto em estar em situações sociais, ou seja, nem a prática, envolvimento e vida escolar, tantas situações sociais as fazem ter tranquilidade em momentos assim. É possível ainda supor que este mal-estar tenha se dado em algum momento de suas vidas escolares como o próprio autor do texto coloca quando fala da criança ferida na idade escolar. 
A segunda questão que mais professoras responderam "sim" foi a 6A, para relembrá-la Frequentemente tem conflitos com seus companheiros de trabalho? $6 A$ - E com as pessoas da família? Importante que Freud observa em seus estudos clínicos as relações do paciente com sua família, ressaltando como os muitos conflitos que temos estão ligados à relação com nossos familiares.

Na questão 9 - Você sempre procrastina as coisas? Também pontuada pelas professoras é possível pensar interferências e/ou consequências de uma vida escolar no âmbito do adiamento das atividades? Talvez as obrigações a nós repassadas desde o início da vida escolar, como os deveres de casa, tenham nos feito perder o gosto pelo cumprimento das tarefas, seja por chegar a nós de modo a ser uma obrigação, seja por serem atividades sem sentido e/ou significado. De todo modo é possível supor que sim, a vivência escolar tenha nos deixado "marcas" que atualmente são reeditadas em nossa postura.

Uma outra das questões que o grupo respondeu "sim" em sua grande parte é a 12 - Tem muito medo de cometer erros? Que apesar de ser acompanhada da $12 \mathrm{~A}$ - Sente-se extremamente humilhada quando é obrigada a constatar os próprios erros? Não teve a mesma repercussão no grupo. Assim como na questão anterior é também possível traçar ligações desta questão do medo de errar com possíveis marcas deixadas pelas vivências escolares. Pergunta-se quem teve suas atividades avaliativas corrigidas de caneta vermelha com " $\mathrm{X}$ " apontando respostas erradas e talvez ainda hoje sinta medo, desconforto ou mesmo pânico ao passar por avaliações? São marcas deste tipo que a vida, escolar ou não, nos deixa e nós as carregamos fazendo releituras destas cenas, e reconhecendo que também são momentos que nos constituem. Essa questão também suscitou como professora/pesquisadora lembranças de um momento como Orientadora Educacional quando da apresentação do plano de ação anual com todas as atividades a serem desenvolvidas na escola. Em certo ano a coordenadora dos Orientadores Educacionais passou para o setor responsável. GOE- Gerência de Orientação Educacional, a pedido deles os nossos planos de ações, que corrigidos com marcações e vários comentários, causaram constrangimento. Muitas relataram que se sentiram como alunas nos anos escolares tendo que seguir um padrão pré-determinado e sendo de uma certa maneira julgadas pela maneira como se deu a correção, marcas constituintes recordadas e repetidas.

Ao indagar se alguma das questões do questionário remeteu a lembranças escolares, uma professora se manifesta. Para ela a primeira questão: Você costuma se comparar com outras pessoas e sempre se sente inferior? a fez lembrar de um momento que vivenciou em sala de aula no seu terceiro ano onde a professora regente decidiu falar das características dos alunos 
através da letra em sala de aula. A professora que faz esse relato se refere a essa atividade como "dinâmica muito infeliz" e continua falando em tom de deboche que na avaliação da sua exprofessora ela tinha complexo de inferioridade e complementa "isso numa turma de adolescente, é péssimo, é a pior coisa que você pode fazer". O professor Paulo interfere após a fala da professora para explicar que o complexo de inferioridade tem conceito diferente do que aprendemos no senso comum. E que significa que quando se tem alguma característica que te torna inferior ao outro, você a usa como motivação, alavanca para ser tão bom ou melhor que os outros que não sofrem com tal inferioridade. Em seguida a professora que fez o relato afirma que "de certa forma foi o que ela fez", referindo-se ao conceito de complexo de inferioridade.

O próximo relato é de outra participante que se lembra de uma professora de matemática que teve na terceira e quarta série a quem tinha horror como ela mesma coloca. Conta uma prática que essa professora tinha em sala: cobrar a tabuada dos alunos de trás para frente, onde os alunos eram colocados em pé na frente da turma com os braços para trás. Em uma vez que foi cobrada a tabuada do oito, a professora conta que "engasgou, já não sabia mais" e que a "professora começou a me achincalhar. Como assim? Não sai nada dessa cara vermelha? Dessa cara bolachuda? Dessa cara de tomate? [...] Ela vinha e apertava assim - ela aperta as próprias bochechas - vai você não consegue falar? $\mathrm{E}$ as minhas bochechas ficavam mais vermelhas - E a professora continua - Olha que você vai ter um D de novo, você vai ficar de recuperação. E cita várias outras passagens com essa professora [...] eu sempre tirava D, "D" de doido. Essa mulher era doida né?"

Outra professora traz uma memória vivida na UnB- Universidade de Brasília. Ela mesma intitula que é uma memória horrível. Explica que passou por transferência vinda da Universidade Federal da Bahia. Conta que uma professora foi insensível com ela e a situação a marcou. Por precisar voltar à Bahia para visitar sua mãe que estava com câncer, faltou os primeiros dias de aula. E em seu retorno a professora da UnB a recebeu e afirmou que ela estava reprovada por faltas, ainda que sua explicação fosse plausível. O sofrimento foi grande visto que a professora não queria nem escutar seus argumentos.

Após dar o comando às professoras de que escolhessem um sentimento para intitular a memória compartilhada o professor Paulo as escutas. Para uma o sentimento foi de inferioridade ao ter sua personalidade analisada por uma professora para toda turma a partir de sua letra, para outra com o sentimento raiva, quando houve insensibilidade por parte de uma professora.

Uma professora que ainda não havia participado decide então relatar a memória que passou em uma aula de matemática. Seu professor da sétima série era chato e queria sempre 
silêncio, segundo compartilha. Um dia algum colega assobiou e ele começou a gritar muito em sala. A situação já estava insuportável e ela decidiu se comprometer assumindo o que não havia feito. O resultado foi que o professor ficou com bastante raiva logo ela que não dava "trabalho" em sala e acrescentou que os pais nunca foram chamados na escola para nada, mas reconhece que a experiência foi de certa forma libertadora. A partir dessa vivência o medo que ela tinha do erro foi substituído pela sensação de liberdade e acrescenta que seu aprendizado na disciplina melhorou.

O professor Paulo esclareceu que o autor deste questionário quis identificar "as feridas" que o período escolar causou na pessoa e pergunta: quais são os remédios que vocês encontraram a partir dessas vivências? Ressaltamos as respostas superação, amorosidade, estar com / estar só, tranquilidade, reconhecer-se. No relato das vivências os sentimentos foram: constrangimento, inferioridade, raiva, medo...

Uma professora reconhece que essas experiências vêm para nos fortalecer e que enquanto adultos precisamos cuidar, fortalecer essas crianças - as que encontramos em sala.

\section{$6^{0}$ Encontro}

\section{Matutino:}

O sociopsicodrama iniciou com a direção do professor Paulo sugerindo momentos de trocas com utilização de alguns instrumentos como lantejoulas, botões, pequenas peças onde cada uma simbolizava e remetia a algo.

5. Bom-dia!

6. Gratidão

7. $\quad$ Perdão- pedir ou dar perdão

8. História de vida- compartilhar

Cada professora recebeu a mesma quantidade de pecinhas que possuíam o significado de bom-dia, gratidão, perdão ou história de vida e foi solicitado que distribuíssem entre si. No final todas contaram quantas cada uma ficou e sua repercussão no sentido do significado. Entre elas foram dando as explicações. Dei a gratidão para minha colega pois ela sempre me ajuda nos planejamentos, distribui bom-dia a todos e fiquei sem nenhum, aproveitei para pedir perdão, recebi muita gratidão, minha história de vida guardei comigo e assim foram tecendo comentários.

O professor percebeu que havia uma demanda maior no grupo, um tom de segredo de "diário", perguntou o que estava acontecendo e foi perceptível o mal-estar. Pediu que todas se sentassem e que falassem o que estavam sentindo. 
Sendo assim, surgiu no grupo o comentário com relação a assembleia dos professores, onde em coordenação haviam decidido paralisar para que todas participassem. No dia da assembleia apenas algumas foram e o grupo se sentiu dividido pois onde se é tomada uma decisão e algumas não cumprem, surgiu o mal-estar no sentido de luta da classe, onde são um grupo e precisam se fortalecer. No momento da fala de quem tinha comparecido à assembleia, muitas se sentiram no direito de se defender e explicar o motivo de não ter comparecido. Tal como esse argumento e outros: estava indo com outra colega de carro e meu carro é preto igual ao Uber. Estava tendo uma manifestação dos taxistas onde depredavam os carros de quem era Uber e como estava próximo ao local da assembleia preferi ir embora com medo de retaliação. Voltamos para escola e cumprimos nosso horário, não fomos para casa... Já eu preferi elaborar minha prova na escola, estou muito atrasada com várias demandas...

Diante das falas, o professor diretor de cena decidiu fazer um axiodrama (método sociátrico vindo do sociodrama mas que emite anseios morais e valores).

Constituiu a seguinte cena representada. (com cadeiras)

Segredo

Mal estar
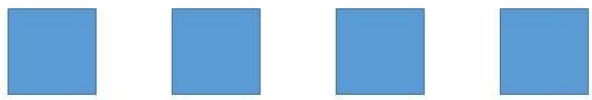

Quadro 7 - Axiodrama

Ao final cada um ia se colocando como no lugar do mal-estar, assembleia, uma foi o segredo velado e percebemos que uma viu a cena toda de fora e não quis participar. Disse não se sentir bem vivendo esses momentos. Foi perceptível o fio de tensão, as expressões de desconforto, julgamento, afirmação, algumas na fala demonstraram revolta pelo acontecido e algumas possuíam a necessidade de se defender em todos os momentos da condução do axiodrama. Foi interessante contemplar através das falas o desvelar do segredo, onde todas se 
sentiam incomodadas por alguma questão, mas não tinham tido oportunidade de se expressar e reelaborar esse momento. Questões como essa remetem posturas políticas, posições de valores, morais e sociais que causam transtornos quando não resolvidas. A solução do problema se deu vivenciando a situação e se colocando no lugar do outro, o desabafo é muito importante assim como se sentir escutado em seus anseios. Foi muito interessante! Mesmo não inserida na proposta do curso, certamente vivenciamos um dos fundamentos da psicanálise a de que não controlamos tudo!

A dinâmica vivida foi encerrada com a pergunta: como cada um entendeu esse momento? Cada um tirou para si conclusões.

\section{Vespertino}

O sociopsicodrama iniciou com a fala do professor Paulo onde ele sugeriu momentos de trocas, assim como no grupo vivido pela manhã, com utilização de alguns instrumentos como lantejoulas, botões, pequenas peças onde cada uma simbolizava e remetia a algo. Chamou esses instrumentos de gotas.

1. Boa tarde!

2. Gratidão

3. Perdão- pedir ou dar perdão

4. História de vida- compartilhar

$\mathrm{O}$ momento de trocas foi bem demorado e algumas faziam confidências em segredo. $\mathrm{O}$ professor Paulo deixou o grupo bem à vontade e após o término da distribuição das gotinhas todas foram contar e se indagavam o porquê de receber tantas gotinhas de gratidão, perdão. Algumas pediram para levar para casa as gotinhas e tiveram permissão. Muitas contaram a cumplicidade que existe no grupo, já que muitas trabalham na escola há um bom tempo e podem contar com a ajuda entre elas. Surgiu a memória de uma professora (história de vida) que trouxe a questão do dever de casa, nos primeiros dias de aula, a professora disse estar tão deslumbrada com a nova escola, que esqueceu de fazer o dever de casa, ficou brincando, já que estava retornando das férias. No dia seguinte a professora regente foi conferir e dar o visto nos cadernos e quando chegou a vez dela a professora disse com ar de deboche que as férias haviam terminado, que precisavam estudar. A moleza acabou! Se sentiu tão envergonhada que nunca mais esqueceu de fazer um só dever. E que hoje entende os seus alunos e tem um outro olhar quando não fazem o dever. Tenta compreender e ajudar. Marcas que ressignificam e constituem.

Ao final cada uma disse como estavam suas sensações no sentido do perdão (culpa) ou gratidão (dever cumprido) e como essas pérolas de recordação se deram. 


\section{$7^{0}$ Encontro}

Neste encontro encerramos o curso. Num primeiro momento lemos uma citação da Cifali que foi comentada pela professora Inês Almeida: “A Cifali faz o quê? Se não dizer para nós que quando você está educando, seja o seu aluno na creche até a pós-graduação, eu estou me vendo - no aluno - na verdade o aluno é um espelho. E nós temos que fazer as pazes com a criança que está dentro de nós, 'pra' eles não fazerem acerto de conta [...] porquê é um processo inconsciente. Você sofreu? Ah! Vou descontar, e principalmente onde desconto? Na avaliação, na prova, né?”. Esta fala dela nos clareia como nós, nossa criança interior reage diante da outra, nosso aluno. Apontando a avaliação como a principal "arma" do professor, que por meio dela ele pode fazer exigências descabidas ou injustas, não antes trabalhadas, apresentadas ao aluno, como forma de punição daquele sujeito que está ali e reflete um pouco de nós, onde nos reconhecemos ou não.

Depois encaminhamos o encontro para a apresentação de um vídeo pout pourri, chamado Ao mestre, com carinho, feito por ex-orientandas da professora Inês Almeida para um curso de formação de professores, um grupo chamado Memórias-Vivas. A professora Inês faz referência a um trecho do filme Sociedade dos Poetas Mortos em que o professor Keating sobe na mesa no intuito de se lembrar e mostrar aos alunos que constantemente temos que mudar nosso ponto de vista e a professora esclarece que não necessariamente devemos subir na mesa literalmente, mas subir metaforicamente nos "ombros" de pensadores para mudar nosso olhar indicando a importância da formação continuada.

Agradecemos ao grupo de professoras pelo acolhimento, aceitação do curso, participação com a escrita da memória educativa e especialmente pela entrega e confiança em relatar suas memórias. Para finalizar pedimos que preenchessem a avaliação do curso e confraternizamos. 
Avaliação das professoras com relação ao curso

\begin{tabular}{|c|c|c|}
\hline AVALIAÇÃO & & \\
\hline Sentimento geral ao longo do curso & 1 & \\
\hline Repercussões do que foi trabalhado & 0 & \\
\hline Experiência da retomada de sua memória educativa & 0 & \\
\hline Auxílio do curso em seu trabalho & 9 & 4 \\
\hline Interesse em dar continuidade nos estudos deste tema & 8 & 5 \\
\hline Sentimento na realização do Sociopsicodrama & 0 & 1 \\
\hline
\end{tabular}

Recebemos 13 (treze) avaliações das professoras referente ao curso. Percebemos que o curso em si suscitou nas professoras uma reflexão no sentido de pertença de grupo, onde puderam trocar ideias, se abrir no sentido de opiniões e visão de mundo. Em um geral a grande maioria gostou de ter participado do curso e achou que de alguma forma repercutiu em seu trabalho de sala de aula, proporcionando até um maior entendimento do seu "ser" professora. Gostaram de fazer a memória educativa fazendo reviver momentos significativos e se encontrando hoje sendo imagem de uma constituição cheia de significados. Algumas pela própria história de vida não conseguiram escrever sua memória, não se permitiram esse momento. Muitas se interessaram tanto pelo tema que disseram ter vontade de continuar os estudos no tema do infantil e psicanálise. Esse fato se presentificou quando no encerramento comentamos com todas a respeito do Lepsi- Laboratório de Pesquisas e Estudos Psicanalíticos e Educacionais sobre a Infância, XI Colóquio Internacional, II Congresso Brasileiro da Red INFEIES (Brasil e América Latina), VI Congresso da RUEPSY (Brasil e Europa) e II Simpósio 
de Psicanálise e Educação de Minas. Colóquio Internacional que acontece de dois em dois anos e esse ano de 2016 se deu em Belo Horizonte já no XI encontro no período de 20 a 23 de setembro e cujo tema: Os sintomas na educação de hoje: O que fazemos com "Isso"? Explicamos que seria submetido o nosso trabalho vivenciado por elas. Fizemos o convite e passamos as informações pelo grupo criado a respeito do curso. Para nossa alegria uma cursista se inscreveu e participou de todo colóquio com muito interesse levando o que tirou de significativo para as colegas da escola e para o grupo de orientadoras educacionais repercutindo para além do que imaginávamos. Podemos perceber os impactos do Colóquio pelo tema em questão que trouxe a questão do sintoma e do "isso". O sintoma no sentido da psicanálise não é um sinal de uma doença, mas um fenômeno subjetivo constituído pela realização deformada do desejo; isto é, uma mescla de restrição e satisfação que faz o sujeito fixar-se nele sem ceder à decifração. Nesse sentido, o sintoma pode ser aquilo que as pessoas têm de mais real. E o "isso" nada mais é que o inconsciente freudiano. Foi clara a visão que tivemos de todo o trabalho em sua vicissitude focando o sujeito em sua singularidade.

Em meio as avaliações das professoras surgiram os seguintes depoimentos. Não pedimos identificação para que ficassem à vontade nas colocações.

A realização deste curso foi de grande valia, pois pude rever alguns conceitos que tinha adquirido na academia e compartilhar minha trajetória educativa que exerce influência na minha profissão docente. Além disso, refleti sobre a dificuldade de incorporar o conhecimento de forma a atuar adequadamente em sala de aula, as vezes o controle nos escapa e o invisível fala. Por isso, a realização deste curso, com recurso do psicodrama, nos ajudou a refletir na importância de se oferecer uma educação mais humana. Acredito que o curso, com o tempo, produzirá efeitos mais visíveis, mas, certamente já deixou marca positiva em minha trajetória de vida.

As reflexões sempre necessárias sobre quem somos e como isso interfere no meu trabalho, nas minhas relações com as crianças, as famílias, as colegas e demais profissionais de apoio.

Ótima oportunidade para aprender de uma maneira suave e ao mesmo tempo intensa. Gostei dos momentos de reflexão. Ter podido escrever as memórias foi ótimo para precisar minha trajetória como pessoa e profissional. Hoje agradeço. O psicodrama foi interessante. Se abrir é mais dificil, mas vamos tentando e caminhando. Percebi o que fui e o que sou. 
A princípio achei o tema complicado, não buscaria este assunto num curso. A organização e a apresentação feita pelo grupo foi tranquila, fato que tornou com que o assunto tratado fosse recebido muito melhor do que eu esperava.

O curso suscitou muitas reflexões sobre a formação da subjetividade e um resgate de nossa própria construção como sujeito, possibilitando a percepção sobre nossas múltiplas condições, tanto como educando quanto como educador. Acessar a memória de nosso processo educativo me fez perceber cada vez mais como a afetividade e a sensibilidade são importantes para o aprendizado e na relação professor-aluno. É importante respeitar o processo de construção de cada um, valorizar a diversidade de expressões e abrir espaços para que cada um dê sentido a seu próprio caminho.

Pude relembrar experiências escolares, principalmente da minha infância. Não gosto de dinâmica, portanto não me senti bem em participar das atividades de sociopsicodrama.

Percebo que a retomada das minhas memórias acontece diariamente na prática com meus alunos. O curso me ajudou a relembrar situações da infância, meu olhar para escola e os mestres, a trajetória na UnB, a minha postura enquanto estudante desde a primeira escola. Refletir sobre a postura de estudante e de educador possibilita não deixar calcificar uma postura estanque, pois somos professores aprendentes e alunos ensinantes a todo momento. Ter a possibilidade de compor a nossa prática, refletindo e agindo é muito rico! Deveria existir módulos complementares!

Relembrei das experiências que tive quando criança, experiências boas e negativas. Confesso que o sentimento que tenho em relação as negativas é de superação. Sempre usei as minhas experiências ruins da escola para moldar o meu trabalho, pois é o professor que eu não quero ser e as experiências que eu não quero causar nos meus alunos. Quero fazer a diferença na educação dos meus alunos, diferença positiva, para que eles sejam a diferença em suas próprias vidas e no mundo.

Reflexão em minha prática pedagógica, reviver e relembrar as boas lembranças $\boldsymbol{e}$ aprendizagens exitosas que podem e devem ser presentes em meu dia a dia com meus alunos. Foram momentos alegres, reflexivos e prazerosos com afetividade, criatividade, com bases teóricas e científicas. Agradeço essa nova oportunidade de repensar e perceber minha atitude pessoal e profissional.

Desde o início o curso suscitou o desejo de retomar...talvez no exato momento de voltar a debruçar ao estudo e à teoria após 20 anos de vivência prática no universo da escola pública perpassando por realidades diversas. Fazer a memória educativa e voltar no túnel do tempo 
das aprendizagens possibilitou vivenciar emoções, saudades, lembranças, as mais diversas. E como não somos apenas profissionais, mas também filha, mãe, irmã, mulher, gente, tudo se encontra num enorme turbilhão de sentimentos que nos fazem ter um compromisso ainda maior com a existência e com aqueles que nos rodeiam cruzando nossa caminhada. Gratidão.

Suscitou extrema alegria e prazer. Percebi efeito no meu curso que estou fazendo na EAPE (A arte de contar histórias) e também no meu dia a dia, principalmente, no meu intimo que me dá vontade até de molhar os olhos de lágrima. O trabalho é excepcional.

Foi muito bom lembrar de muitas coisas desse ambiente tão delicioso. Encontrar professoras e relembrar bons e lindos momentos. Com relação aos efeitos no trabalho percebi algumas mudanças e reflexões que as vezes passam devido a correria do dia a dia. Obrigada por todos os momentos e lembranças agradáveis.

Percebi a importância do olhar/relembrar o passado para possíveis entendimentos/esclarecimentos de atitudes que hoje eu não compreendia. Ressaltar a importância também como educadora e minha influência perante as memórias afetivas dos meus alunos. Contudo hoje percebo quão delicada são nossas memórias, quão necessário é ter esse olhar e agradeço principalmente as dinâmicas que me fizeram pertencer ao mundo de aluno nessa minha jornada como educadora. 


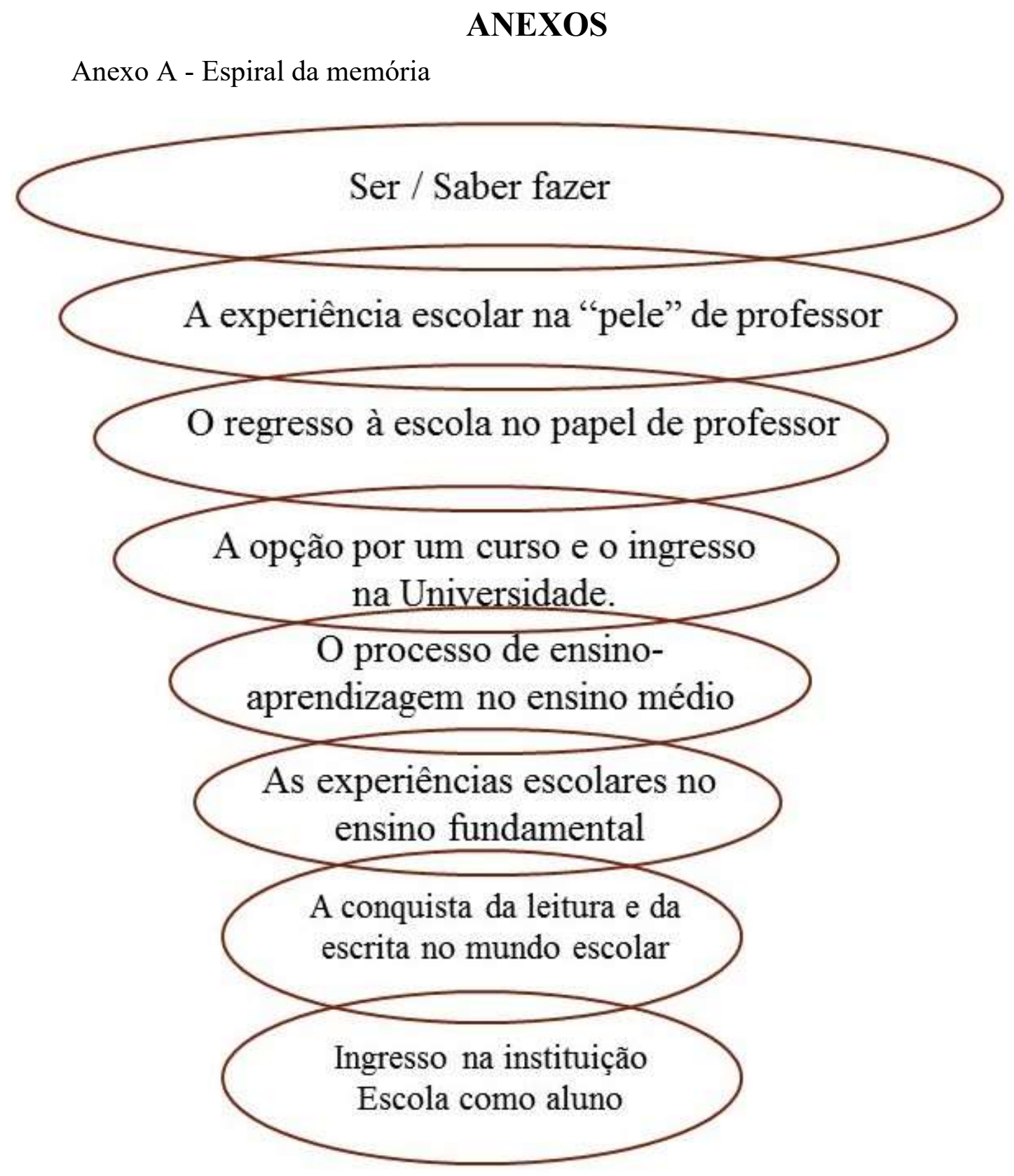

Figura 3- Espiral da memória educatica 


\section{Anexo B - Proposta a EAPE}

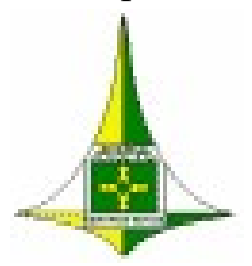

GOVERNO DO DISTRITO FEDERAL

Secretaria de Estado de Educação, Esporte e Laze

Centro de Aperfeiçoamento dos Profissionais de Educação, Esporte e Lazer - EAPE

\section{ASPECTOS ORGANIZACIONAIS}

1. 1 Proposta do curso: o lugar do infantil na memória educativa: implicação e reflexão em escrita e ação.
1.1.1
( ) Proposta de Curso Estruturante

1.1.2

(X ) Proposta de Curso Especifico

1.2 Proponentes

EAPE e/ou Setores da SEDF

Gerência responsável

\begin{tabular}{|l|l|l|}
\hline Gerente & E-mail
\end{tabular}

\begin{tabular}{|l|l|l}
\hline Articulador & E-mail
\end{tabular}

\begin{tabular}{|l|l|}
\hline Instituição Parceira da EAPE & E-mail: almeida@unb.br \\
\hline Nome da Instituição: Universidade de Brasília - UnB & \\
\hline Responsável pelo curso: Prof. Dra. Inês Maria M.Z.P. de Almeida & E-mail \\
\hline Articulador da EAPE &
\end{tabular}

\subsection{Público}

Público exclusivamente de professores e servidores da carreira magistério dos anos iniciais do ensino fundamental da Escola Classe 304 Norte.

\subsection{Articulador da EAPE}

\section{Elementos Pedagógicos}

Elementos Administrativos

\subsection{Critérios para inscrição e seleção}

Declaração de lotação e função na Escola Classe 304 Norte.

\subsection{Divulgação \\ - Período \\ - Meios}


- Responsável pela divulgação

1.7 Inscrição

- Período

- $\quad$ Local de Inscrição: www.eape.se.df.gov.br

1.8 Seleção

1.9 Carga horária total : 80 horas

1.10 Modalidade/distribuição da carga horária do curso

(x) Presencial

( ) Híbrido

\begin{tabular}{|l|c|c|}
\hline Carga horária direta & 30 horas \\
\hline Carga horária no AVA & 50 horas & 80 horas \\
\hline Carga horária indireta & \\
\hline
\end{tabular}

1.11 Realização do Curso

\begin{tabular}{|c|c|c|c|}
\hline \multirow[t]{2}{*}{ Turma } & Local & Endereço & \\
\hline & & & Início \\
\hline A & $X X X X X$ & $X X X X X X$ & $13 / 04 / 2016$ \\
\hline B & $X X X X X X X$ & $X X X X X X$ & $13 / 04 / 2016$ \\
\hline
\end{tabular}

1.12 Vagas

Curso com destinação específica para os sujeitos de pesquisa.

\section{ASPECTOS TEÓRICO-METODOLÓGICOS}

2.1 Objetivo geral do curso

Compreender a dimensão do infantil na constituição da subjetividade de professores à luz da teoria psicanalítica. Refletir e analisar a importância da dimensão amorosa ( reconhecimento do Outro), da presença e da palavra no processo de transmissão dos ensinamentos.

2.2 Justificativa

Esse curso destina-se a coleta de dados necessários para realização de pesquisas propostas:

- $\quad$ Em projeto de dissertação já qualificado do PPGE da Faculdade de Educação da UnB intitulado O infantil na constituição da subjetividade: o memorial educativo de professores em escrita e ação.

- Em projeto PIBIC pelo departamento de Teorias e Fundamentos da Faculdade de Educação da UnB intitulado Psicanálise, educação e transmissão: ensina-se por dever, aprende-se por amor.

2.3 Fundamentação teórica 
O curso será fundamentado em especial nas concepções advindas da Psicanálise e Sociopsicodrama. Com a utilização dos autores Freud Blanchard-Laville, Kupfer, Lajonquière, Moreno, Nasio, Plastino, Tanis, Voltolini, dentre outros.

2.4 Objetivos específicos quanto às aprendizagens esperadas

- Reconhecer como o conhecimento do infantil na constituição da subjetividade docente qualifica o processo educativo, em especial, no cenário de sala de aula.

- Identificar possíveis implicações da atuação do professor de educação dos anos iniciais do Ensino Fundamental na constituição da subjetividade infantil.

- Analisar as concepções de transmissão no fazer pedagógico, suscitando reflexões inspiradas no saber psicanalítico.

- Estabelecer questionamento se há alguma forma de o discurso amoroso na educação possibilitar a transmissão, sem que seja padronizado, valorizando, mediante os ensinamentos de Freud sobre a dimensão dos afetos inscritos na ordem do inconsciente em relações de ensino-aprendizagem.

2.5 Conteúdos/temas abordados que serão listados para fins de certificação (seguir ordem alfabética de temas ou assuntos)

- $\quad$ Articulações Memória e Sociopsicodrama.

- $\quad$ Constituição da Subjetividade e o infantil freudiano.

- Memória Educativa.

- O lugar da memória na Psicanálise.

- O percurso do afeto no cenário pedagógico.

\begin{tabular}{|c|c|}
\hline Data (dia e mês) & Conteúdos/estratégias/procedimentos de ensino \\
\hline $13 / 04 / 2016$ & $\begin{array}{l}\text { Apresentação teórica dos temas que serão abordados e do objetivo do curso de extensão como fonte de pesqu } \\
\text { professores e equipe pedagógica a proposta e desenvolvimento do curso. Palestra inicial: conhecendo a psicaná }\end{array}$ \\
\hline $27 / 04 / 2016$ & $\begin{array}{l}\text { Memória Educativa, o lugar da memória na Psicanálise, constituição da Subjetividade e o infantil freudiano, articulações Memória e Socio } \\
\text { Apresentação do dispositivo da memória educativa. Implicações da dimensão do afeto nas práticas escolares. }\end{array}$ \\
\hline $11 / 05 / 2016$ & $\begin{array}{l}\text { Sociopsicodrama - serão realizadas nas oficinas que podem levar a aproximações possíveis entre memória educati } \\
\text { Considerando os enfoques na trajetória percorrida pelo sujeito: educação básica, ensino médio, superior e a e } \\
\text { pele do professor. }\end{array}$ \\
\hline $25 / 05 / 2016$ & Realização de entrevistas \\
\hline $08 / 06 / 2016$ & Realização do sociopsicodrama \\
\hline $22 / 06 / 2016$ & Realização do sociopsicodrama \\
\hline $06 / 07 / 2016$ & Encerramento \\
\hline & $\begin{array}{l}\text { A flexibilização dos conteúdos, estratégias, procedimentos de ensino estarão assegu } \\
\text { intercorrências. }\end{array}$ \\
\hline
\end{tabular}

2.7 Recursos didático-pedagógicos

Entre os mais utilizados serão: Power Point, slides, textos impressos, filmes dentre outros que possam ser incluídos durante o desenvolvimento do curso.

2.8 Certificação de formador, palestrante, convidado ou colaborador

2.8.1 No caso do formador possuir alguma deficiência listá-la no campo Especial

\begin{tabular}{|c|c|c|c|c|}
\hline Matrícula & Nome e titulação & Especial & $\begin{array}{c}\text { Conteúdos / temas } \\
\text { ministrados }\end{array}$ & \\
\hline & Profa. Dra. Inês Maria Zanforlin Pires de Almeida & & Formadora & 80 horas \\
\hline & Prof. Dr. Paulo Sérgio de Andrade Bareicha & & Formador & 80 horas \\
\hline & Mestranda Katilen Machado Vicente Squarisi & & Formadora & 80 horas \\
\hline & Graduanda Maria Cláudia Aguiar da Silva & & Formadora & 80 horas \\
\hline
\end{tabular}

\subsection{Referências}

ALMEIDA, Inês Maria M. Z. Pires de. Ressignificação da Psicologia da Educação na Formação de Professores de Ciências e Matemática. Tese de doutorado. IP-UnB (2001).

FREUD, Sigmund. Obras completas de Sigmund Freud. Ed. Standard Brasileira. Rio de Janeiro. Imago, 1996.

TANIS, Bernardo. Memória e Temporalidade. Sobre o infantil em psicanálise. São Paulo: Casa do Psicólogo, 1995. 
LAJONQUIĖRE, L. D. Infância e ilusão (Psico)Pedagógica. Escritos de psicanálise e educação. Petrópolis: Vozes, 1999.

MARRA, M. M.; FLEURY, H. J. Sociodrama, um método, diferentes procedimentos. São Paulo: Ágora, 2010.

MONTEIRO, A. M.; MERENGUÉ, D.; BRITO, V. Pesquisa quantitativa e psicodrama. São Paulo: Ágora, 2006.

Vídeos:

Freud Além da Alma

Sigmund Freud: a invenção da Psicanálise

Minha vida em cor de rosa

\section{ASPECTOS INSTITUCIONAIS}

O Centro de Aperfeiçoamento dos Profissionais de Educação, Esporte e Lazer - EAPE é responsável, entre outros, por:

- $\quad$ aprovar a proposta de curso;

- $\quad$ acompanhar a execução do curso por meio de um articulador da EAPE;

- $\quad$ aplicar a avaliação institucional do curso.

Para tanto, serão implantadas as ações a seguir.

- Ata de Frequência

Utilizar a ata de frequência eletrônica, implantada na EAPE, conforme orientações constantes na Portaria $n^{\circ} 35$, de 20 de fevereiro de 2014, sob a responsabilidade do Setor de Documentação da EAPE (das $8 \mathrm{~h}$ às $12 \mathrm{~h}$ ou das $14 \mathrm{~h}$ às $17 \mathrm{~h}$ ).

- Avaliação do Curso

A EAPE fará a avaliação institucional do curso por meio eletrônico no site de avaliação de cursos da EAPE. Serão aplicadas as avaliações processual e final, conforme orientações da Gerência de Pesquisa, Avaliação e Incentivo ao Desenvolvimento Profissional (das $8 \mathrm{~h}$ às $12 \mathrm{~h}$ ou das $14 \mathrm{~h}$ às $17 \mathrm{~h})$.

\section{- Relatório}

O Relatório Final de Curso deverá ser elaborado conforme orientações do setor responsável da EAPE.

\section{- Certificado}

O certificado será emitido por meio eletrônico, conforme orientações constantes na Portaria $\mathrm{n}^{\circ} 35$, de 20 de fevereiro de 2014 , sob a responsabilidade da EAPE.

Será exigido $100 \%$ de frequência, admitindo-se $20 \%$ de faltas justificadas.

A emissão do certificado será liberada após avaliação da participação e realização das atividades do cursista pelos formadores do curso.

\section{Autorização Final do Curso}

A apreciação e a aprovação do curso estão sob a responsabilidade da Chefia, da Diretoria de Formação Continuada, Pesquisa e Desenvolvimento Profissional - DIDEP e de suas gerências e em consonância com as políticas públicas de educação do Distrito Federal.

A autorização só será efetivada após o preenchimento dos campos abaixo discriminados, contendo data e assinatura com carimbo da:

\begin{tabular}{|c|r}
\hline $\begin{array}{c}\text { Diretoria de Formação Continuada, Pesquisa e Desenvolvimento } \\
\text { Profissional - DIDEP }\end{array}$ & Gerência \\
\hline
\end{tabular}


ANEXO

Nome do curso/evento

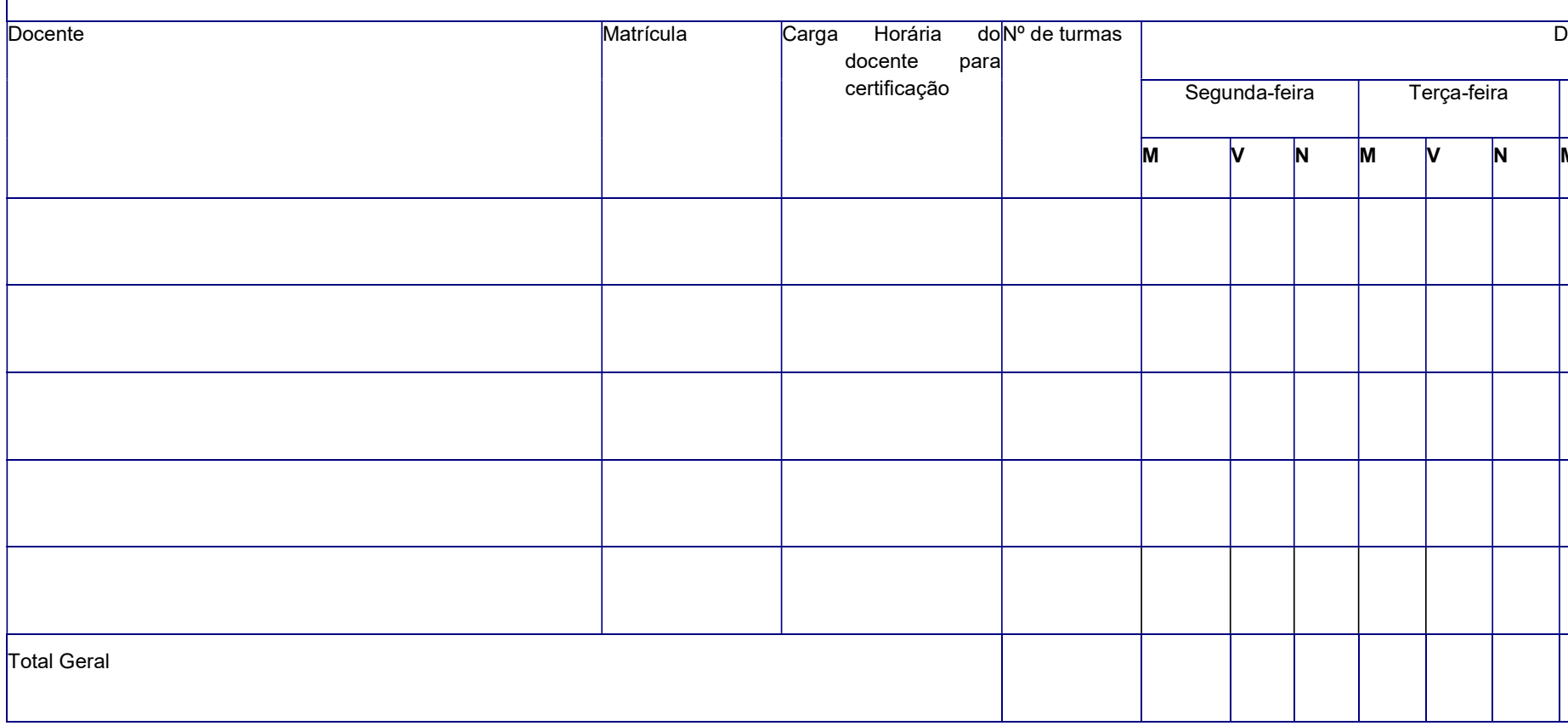

